Georgetown University Law Center

Scholarship @ GEORGETOWN LAW

2018

\title{
The Tethered President: Consistency and Contingency in Administrative Law
}

William W. Buzbee

Georgetown University Law Center, wwb11@georgetown.edu

This paper can be downloaded free of charge from:

https://scholarship.law.georgetown.edu/facpub/2066

https://ssrn.com/abstract=3175473

98 B.U. L. Rev. 1357-1442

This open-access article is brought to you by the Georgetown Law Library. Posted with permission of the author. Follow this and additional works at: https://scholarship.law.georgetown.edu/facpub

Part of the Administrative Law Commons 


\section{THE TETHERED PRESIDENT: CONSISTENCY AND CONTINGENCY IN ADMINISTRATIVE LAW}

WILLIAM W. BUZBEE*

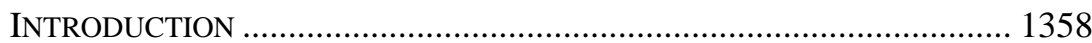

I. The Regulatory Whim And POLICY Change POWER

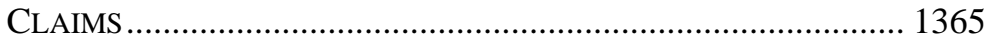

A. The Congressional Expectation of Agency Policy

Adjustment ........................................................................ 1366

B. The Justice Neil Gorsuch Regulatory “Whim” Theory.... 1368

C. The Ossification and Agency Inertia Theories ................... 1371

D. Agency Overreach Concerns and the "Major Questions"

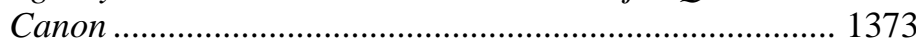

E. The Trump Administration and Embrace of Change

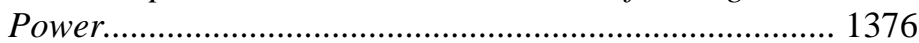

1. The Two-for-One Executive Order ............................. 1376

2. The Agency Stay and Delay Two-Step ...................... 1378

3. Splintering Deregulatory Steps.................................... 1378

4. Agency Statutory Abnegation Claims .......................... 1378

5. Environmental Deregulating with Inattention to Science and Past Reasoning

II. Agencies, PRESIDENTS, AND Policy ChANGE CONDITIONS ........ 1390

A. Enabling Act Constraints .................................................... 1390

B. Policy Change Process, Deliberative Opportunities, and

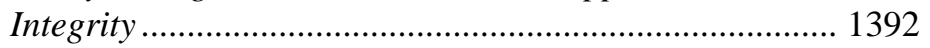

C. Inconsistency, Politics, and Facts ....................................... 1396

D. Additional Consistency Meta-Rules.................................... 1401

E. Reasoned Decisionmaking as a Constraint ...................... 1403

F. Agency Record and Deliberative Conformity................... 1407

G. The Losing Track Record of Poorly Explained Policy Changes ............................................................................. 1408

\footnotetext{
* Professor of Law, Georgetown University Law Center, wwb11@law.georgetown.edu. The author thanks Vicki Arroyo, Robert Glicksman, Nicholas Parillo, Andrew Schoenholtz, Peter Strauss, David Vladeck, and Susannah Weaver; the faculty of Georgetown Law who provided workshop comments; Thanh Nguyen and Andrea Muto of Georgetown Law's library; research assistants Samuel Gray and Kiernan Moran; participants in the 2017 Administrative Law Discussion Forum held in Paris, France; and the 2018 Legislative Roundtable held at Fordham Law School in New York City.
} 
H. The Trump Administration Regulatory Shortcuts and Judicial Rejections..... 1412

III. DEREGULATION AND THE CONSTRAINTS OF AGENCY

CONTINGENCY 1417

A. Distilling and Diagramming Consistency Doctrine's Requirements

B. Assessing Major Deregulatory Proposals by the Trump Administration 1420

C. Consistency Doctrine's Policy Merits ................................. 1424

IV. DeLIBERATIVE INTEGRITY AND TETHERING's DEGREES ................ 1426

A. The Presidential Nudge and Enforcement Prioritization . 1427

B. Turf Conflicts. 1429

C. Broad New Deal Delegations ............................................. 1429

D. Science-Based Judgments and the "Best".......................... 1430

E. Presidential Adjudicatory Interventions............................ 1432

F. Statutory Abnegation and Dodged Facts.......................... 1433

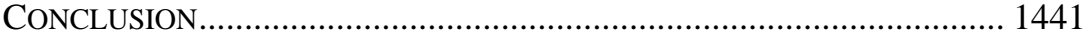

The law governing administrative agency policy change and the checking of unjustified inconsistency is rooted in a web of intertwined doctrine. The Supreme Court's 2016 opinion in Encino Motorcars modestly recast that doctrine to emphasize that the agency pursuing a change cannot leave "unexplained inconsistency" or neglect to address past relevant underlying facts, but reaffirmed its central stable precepts. Nonetheless, radically different views about broad, unaccountable, and agency power to make rapid policy changes have been articulated by Justice Neil Gorsuch while on the Tenth Circuit and by agencies pursuing deregulatory policy shifts under the leadership of President Donald J. Trump. This Article analyzes the mutually reinforcing strands of this body of law, shows the fundamental errors underpinning these claims of broad agency power to make policy changes, and explains how the "contingencies" underlying an initial policy action must always be engaged by a later advocate of policy change. Statutory language constrains agency action while usually leaving room for change, but facts and past agency reasoning-the heart of regulatory "contingencies" focused on in this Article-unavoidably must be engaged to surmount the sturdy core requirements of consistency doctrine. Recent efforts to overcome or recast consistency doctrine seek greater room for politics and presidential influence and downplay agency obligations to provide rational explanation and engage with regulatory contingencies. Due to the balanced interests protected by consistency doctrine, this Article argues that such a doctrinal reworking is unlikely and would be unwise.

\section{INTRODUCTION}

Indictments of the administrative state vary, but one strain-notably voiced by Justice Neil Gorsuch in a Tenth Circuit opinion shortly before he joined the 
Supreme Court-is that under existing doctrine, agencies can abruptly shift

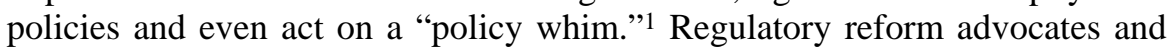
others troubled by deference to agencies under the influential Chevron case have raised similar concerns about agency policy inconsistency. ${ }^{2}$ But not all analysts of agency latitude for change condemn it. New presidential administrations, with the overtly deregulatory administration of President Donald J. Trump being a particularly salient example, at times embrace this alleged power, claiming broad presidential and agency authority to reverse agency policies and even direct agency adjudicatory outcomes. ${ }^{3}$

This Article unpacks different conceptions and doctrines framing agency power to change policy and the role of consistency-linked doctrine. ${ }^{4}$ Under current doctrinal frameworks, these recent claims of agency latitude for abrupt and politicized policy change are erroneous. Agencies and presidents remain tethered by statutory delegations' terms, legal doctrine, and past legal actions. But such tethering implies restraint and limitations, not frozen regulation. Presidents can request agency policy reconsideration and agencies usually retain

\footnotetext{
${ }^{1}$ Gutierrez-Brizuela v. Lynch, 834 F.3d 1142, 1153 (10th Cir. 2016). Justice Gorsuch’s views are reviewed later in this Article. See infra Section I.B.

2 Chevron U.S.A., Inc. v. Nat. Res. Def. Council, Inc., 467 U.S. 837 (1984). A discussion of Chevron deference appears later in this Article. See infra Section I.D; infra notes 188-197 and accompanying text.

3 The extent of presidential authority over agencies remains the subject of scholarly ferment. Compare Steven G. Calabresi \& Saikrishna B. Prakash, The President's Power to Execute the Laws, 104 YALE L.J. 541, 599 (1994) (arguing for expansive presidential control), and Elena Kagan, Presidential Administration, 114 HARV. L. Rev. 2245, 2320 (2001) (arguing that presidential regulatory authority should be presumed to be conferred by statute unless explicitly stated otherwise), with Kevin M. Stack, The President's Statutory Power to Administer the Laws, 106 ColuM. L. REV. 263, 284 (2006) (arguing courts and presidents should respect different congressional choices about delegation to President versus to agency), and Peter L. Strauss, Presidential Rulemaking, 72 CHI.-KenT L. REV. 965, 977-79 (1997) (distinguishing among modes of political control and conceptions of discretion with emphasis on powers delegated to agencies by Congress and Constitution's specified means of presidential control). For an article analyzing this issue historically, through presidential and agency interactions and revealed views about such power, see Robert V. Percival, Who's in Charge? Does the President Have Directive Authority Over Agency Regulatory Decisions?, 79 FORDHAM L. REV. 2487, 2495-500 (2011).

${ }^{4}$ By "agency policy change," this Article refers to the setting where statutory language remains stable, but an agency changes some regulatory policy previously set forth by the agency. A mere change in stringency, for example, is not a policy change. The forms of agency policy change can be numerous, but usually involve a change in approach to regulating a risk, or a changed claim about the nature of an agency's power and related change in regulatory requirements. Such policy changes can be substantially rooted in statutory language, in empirical observations, or a mix of the two. Policy change examples and related cases are reviewed in Parts I and II.
} 
room to make policy adjustments. ${ }^{5}$ Nonetheless, hurdles exist and can be substantial even though policy changes are not subject to a heightened standard of judicial review. Changes cannot be unjustified, purely political, or unacknowledged. ${ }^{6}$

Claims of broad agency policy change authority tend to exaggerate the freedom granted by statutory language and the often-applicable and deferential Chevron judicial review framework. The President's power to precipitate change also tends to be exaggerated without adequate attention to how the permissible degree of influence depends on the particular setting and regulatory posture. Broad claims of policy change power also tend to downplay the regulatory centrality of science, data, other empirical observations and predictions about the world, and linked agency explanations. Agency policy is rarely, if ever, generated due to statutory language alone; later leadership similarly cannot just point to language or presidential edict to justify a change. ${ }^{7}$

By building off of these intertwined doctrinal strains, this Article shows how agencies considering a policy change must engage with the contingencies underlying past and proposed new regulatory actions. Under this analytical frame, anyone evaluating room for a possible agency policy change needs first to assess the legal frameworks and powers they confer and, as is true of all power conferrals, the correlative constraints they state or imply. ${ }^{8}$ Always important are the statutory criteria, goals, and procedures that guide the agency's choices. Then, stakeholders must assess what factors outside the law's text-but made

\footnotetext{
${ }^{5}$ Part IV reviews different policy change settings and the latitude they provide for change, especially change driven by political considerations.

${ }^{6}$ See infra Part II (reviewing categories of actions and legal doctrine that frame and constrain policy change efforts).

${ }^{7}$ For two earlier articles analyzing the puzzle of agency consistency, but preceding recent policy change power claims and case developments, see Yoav Dotan, Making Consistency Consistent, 57 Admin. L. REv. 995, 1029-30 (2005), which focuses upon procedural modes generating old and new policy; and Randy J. Kozel \& Jeffrey A. Pojanowski, Administrative Change, 59 UCLA L. REV. 112, 115 (2011), which distinguishes between “expository” policy declarations rooted in language and "prescriptive" reasoning that is based on policy choices, and calls for de novo review of expository-based changes.

${ }^{8}$ For a modern case that both articulates the centrality of statutory criteria as a constraint and also emphasizes the agency's obligation to engage with underlying facts and science relevant to its task, see Massachusetts v. EPA, 549 U.S. 497 (2007). See also Air All. Hous. v. EPA, No. 17-1155, slip op. at 19 (D.C. Cir. Aug. 17, 2018) (stating that it "is axiomatic that administrative agencies may act only pursuant to authority delegated to them by Congress" and rejecting policy change for several statutory violations, inadequate explanations, and failures to address earlier factual findings (quotations and internal citations omitted)). For two cogent critiques of Massachusetts $v$. EPA, its "expertise-forcing" underpinnings, and its place in the prevalent ongoing tension between the roles of politics and expertise as sources of accountability and legitimacy in regulation, see David J. Barron, From Takeover to Merger: Reforming Administrative Law in an Age of Agency Politicization, 76 Geo. WASH. L. REV. 1095 (2008); Jody Freeman \& Adrian Vermeule, Massachusetts v EPA: From Politics to Expertise, 2007 Sup. CT. REV. 51.
} 
legally relevant due to that text-shaped and explained the earlier agency action and policy that is now proposed for change. ${ }^{9}$ The change advocate must then compare the old and new policy and justify the change through legally required procedures and public vetting, engaging with the old grounds and contingencies and any new variables.

As a shorthand, this Article refers to such non-statutory text variables as contingencies. Their legal significance is determined by each statute's procedural and substantive choices, but most statutes are drafted to leave room for agency policy change due to changed empirical assessments or policy rationales. The contingencies will themselves be external to the statutes and be observable. These are reality-based factors-including past legal documentation, history, regulatory experience, health impacts, science, data, models and predictions, past agency studies, and published explanations of the previous regulatory choice, to name a few such contingencies-that underpin any agency action. As explained below, as a matter of logic and under current doctrine, such contingencies unavoidably must remain part of the analysis and justification for future policy shifts.

Contingencies typically will be the social or physical manifestation of particular decisional criteria explicitly stated in legislation, but not always. Contingencies motivating acceptable agency policy change can, if statutory language leaves such room, involve some mix of trying better means to achieve constant ends, making policy adjustments in light of changing underlying scientific or social phenomena, or expert agency reassessment of the workability or fairness of past approaches. ${ }^{10}$ Although broad delegations to New Deal agencies offer little binding linguistic specificity, even those broadly empowered agencies will, through adjudications and other policymaking modes, identify social problems and devise remedial strategies that adjust and are

9 See Merrick B. Garland, Deregulation and Judicial Review, 98 HARV. L. REV. 505, 57589 (1985) (analyzing how Supreme Court in Motor Vehicle Manufacturers Ass'n of United States, Inc. v. State Farm Mutual Auto. Insurance Co. insisted on agency engagement with statutory criteria and rejected "interest representation" frame or model that would have allowed politics larger role in shaping agency actions). Judge Garland labeled the Court's approach as focused on agency "fidelity to th[e] delegation.” Id. at 589.

${ }^{10}$ Chevron itself involved such a setting. See infra Section II.B (discussing Chevron). 
refined over time. ${ }^{11}$ Such sequential development of policy will similarly identify and link to specified contingencies. ${ }^{12}$

Attention to such contingencies, since they involve far more than just word games, also serves to constrain arbitrary agency change and dampen the frequency and magnitude of policy shifts. Sometimes a policy shift will be rooted mainly in mere linguistic analysis, but that rarely happens. ${ }^{13}$ And close parsing of legislation to assess if Congress anticipated agency policy adjustments will necessarily influence the legality of an agency policy shift. Importantly, the Supreme Court in Massachusetts v. EPA ${ }^{14}$ rejected an agency policy change and declination to act that neglected statutory criteria and also avoided examination of relevant science. ${ }^{15}$ Some agency actions will be driven mostly by language, while others will be driven more by science or observations made salient by statutory language. ${ }^{16}$ Politics can, and indeed does, play a role, but not to the exclusion of other contingency variables and always subject to the need for conformity with statutory requirements. ${ }^{17}$ Administrative law doctrine

11 See, e.g., POM Wonderful v. FTC, 777 F.3d 478, 484 (D.C. Cir. 2015) (upholding FTC claims of false representations, reviewing genesis of statutory and evolution of agency policy, and also rejecting one remedial claim as beyond agency power in light of facts, constitutional concerns, and past agency precedents); Daniel J. Solove \& Woodrow Hartzog, The FTC and the New Common Law of Privacy, 114 Colum. L. Rev. 583, 586, 589, 648-66 (2014) (discussing development of FTC's power and jurisprudence); see also infra Section IV.C (discussing permissible bounds of politics and deliberative integrity when agencies with broad delegations adjust policy).

12 For discussion of how the FTC's privacy law has evolved in a common law-like way, with increasingly specific criteria, see Solove \& Hartzog, supra note 11.

13 Professors Kozel and Pojanowski call such language-based policy derivation “expository.” Kozel \& Pojanowski, supra note 7, at 112. Statutory abnegation claims made by agencies under the Trump Administration - a new claim of no statutory power-has been a prevalent part of this Administration's many deregulatory policy shifts. See infra Sections I.A, III.B, IV.F (discussing policy shifts initiated by federal agencies under Trump Administration).

14549 U.S. 497 (2007).

${ }^{15}$ Id. at 534-35 (holding agency action was arbitrary and capricious as agency gave "no reasoned explanation" for its refusal to act). For further discussion of the ways that statutory language shapes the permissible bounds and deliberative integrity of policy change, see infra Part IV.

${ }^{16}$ As developed further below, see infra Part IV, the judicial role when reviewing a policy change will differ if language is broad or a statute requires an assessment of science, data, or (as commonly required) what is "best" among some category of risk creators. See Ronald M. Levin, Hard Look Review, Policy Change, and Fox Television, 65 U. Miami L. Rev. 555, 565-66 (2011) (distinguishing judicial review task when statute requires agency to provide "factually grounded explanation” as opposed to one grounded in "value judgment[s]").

17 See Kathryn A. Watts, Proposing a Place for Politics in Arbitrary and Capricious Review, 119 YALE L.J. 2, 6-8 (2009) (arguing there is "proper, even if limited, place for politics" in shaping policy choices beyond just "technocratic" approaches to policymaking, but also arguing that evidence and statutory criteria will limit room for presidential influence). 
also creates some trans-agency and trans-law space for agency policy experimentation, but all policy changes are nonetheless cabined or shaped by what relevant statutory language dictates, as well as past regulatory choices and explanations. ${ }^{18}$

The crucial point about consistency doctrine and agency policy change power is that, as a matter of logic and doctrine, deviations from a past policy choice or approach — whether to deregulate, adjust strategies, or increase regulatory stringency-will rarely, if ever, involve just a language game. ${ }^{19}$ If language requires one particular policy action, then change cannot be made. But that is exceedingly rare. Policy change is pursued where language leaves room for adjustment and something about the world is viewed as justifying the change. Scholars and judges debate the degree to which politics can influence agency regulation..$^{20}$ Room for politics and the degree of judicial oversight will hinge on relevant law and the action at issue. ${ }^{21}$ But key governing precedents, whether new or old, always call for some variant of agency engagement with the past action, underlying facts, and earlier rationales or reason-giving explanations.

Because facts and experience are a sticky reality that an agency virtually always documents in justifications for past actions, policy shifts cannot be carried out by executive fiat. ${ }^{22}$ As stated in key consistency precedents,

Some have argued in favor of a more limited place for politics. See Mark Seidenfeld, The Irrelevance of Politics for Arbitrary and Capricious Review, 90 WASH. U. L. REV. 141, 144 (2012) (distinguishing between political motivations and judgments, and agency justification under hard look review); Jodi L. Short, The Political Turn in American Administrative Law: Power, Rationality, and Reasons, 61 DuKE L.J. 1811, 1849-50 (2012) (arguing against Watts and favoring limited room for politicized influence on agencies, even if disclosed).

${ }^{18}$ For example, a new general interpretive presumption is that agencies should consider both regulatory benefits and costs. See Michigan v. EPA, 135 S. Ct. 2699, 2705, 2715 (2015) (embracing in majority and dissenting opinions general requirement that agencies assess costs and benefits unless statute clearly indicates otherwise). The Court has also indicated that agency actions that harness the benefits of market-based regulatory tools and confer regulatory flexibility on states receive what appears akin to a reviewing court "bonus." See EPA v. EME Homer City Generation, L.P., 134 S. Ct. 1584, 1601, 1605-07 (2014) (affirming legality of agency program that provides states with implementation flexibility and harnesses market incentives, and speaking favorably of such designs); William W. Buzbee, FederalismFacilitated Regulatory Innovation and Regression in a Time of Environmental Legislative Gridlock, 28 GEO. ENVTL. L. REV. 451, 474-75 (2016) (discussing these cases).

19 As discussed below, the deregulatory strategy of agency disavowal of power previously claimed, which this Article calls "statutory abnegation," can involve a claim that language alone justifies a new claim of no power. It can also involve a few variants of rejection of earlier power claims. See infra Sections I.E, IV.F.

20 See sources cited supra notes 3, 8-9; infra Part IV (describing this debate).

${ }^{21}$ See infra Part IV (describing constraints on agency's ability to change policy).

${ }^{22}$ Kozel and Pojanowski describe agency attempts to establish stable policy as "gam[ing] the system” or “administrative machinations.” Kozel \& Pojanowski, supra note 7, at 165-66. As explored below, this Article suggests that agency grounding of policy in strong evidence 
including the recent decision, Encino Motorcars, LLC v. Navarro, ${ }^{23}$ an agency must always supply a "good reason" for a policy revision, cannot leave "unexplained inconsistency," and must address underlying "facts and circumstances" relevant to the earlier and new action. ${ }^{24}$

The Supreme Court in Chevron did allow the Environmental Protection Agency ("EPA") to redefine a term and even embraced agency reconsideration of policies, stating that agencies "must" do so to engage in "informed rulemaking." 25 But room for change is separate from satisfying the conditions necessary to achieve it. Neither that case nor any other embraces untethered, erratic, or unjustified reversals or abandonment of statutory missions. ${ }^{26}$

This theoretical frame's deep doctrinal foundations have implications for strategies to reduce risks of erratic policy shifts and regulatory reversals. Agencies and others worried about subsequent regulatory backpedaling, illconsidered policy shifts, or just plain old judicial reversal can - through diligent engagement with underlying science, data, and rationales for a chosen regulatory course-raise hurdles that subsequent agencies, presidents, and even reviewing courts must overcome. ${ }^{27} \mathrm{~A}$ lightly justified initial action, in contrast, will ease the path for a later policy shift. To succeed in making a policy change, agencies will always need to engage with, and with new persuasive reasoning explain, or perhaps explain away, the contingencies that underlay the past agency action.

For a President like Donald J. Trump, who after his 2017 inauguration quickly and aggressively asserted directive power to mandate deregulatory lookback analysis and ordered agencies to revisit specified actions, ${ }^{28}$ the constraints of

and reasoning will create resistance against change, but does not view this practice as illegitimate or problematic.

23136 S. Ct. 2117 (2016).

${ }^{24}$ Id. at 2126; see also FCC v. Fox Television Stations, Inc., 556 U.S. 502, 515 (2009) ("An agency may not ... depart from a prior policy sub silentio or simply disregard rules that are still on the books.”).

25 See Chevron U.S.A., Inc. v. Nat. Res. Def. Council, Inc., 467 U.S. 837, 863-66 (1984).

26 See id. at 853-66 (discussing impacts of old and new approaches, economics scholarship, and efforts to allow cost-effective regulation to achieve clean air as rational and consistent with statute in upholding EPA's new “bubble” approach); Ronald M. Levin, The Anatomy of Chevron: Step Two Reconsidered, 72 CHI.-KenT L. REV. 1253, 1268-69 (1997) (noting that although Chevron's influential opinion alludes to task of “interpretation,” actual opinion involved assessment of how record supported agency's reasoning).

27 See, e.g., Pub. Citizen Health Research Grp. v. Tyson, 796 F.2d 1479, 1505-07 (D.C. Cir. 1986) (reversing and remanding agency decision to carry out last-minute directive by White House Office of Management and Budget without any apparent justification in administrative record and requiring agency to utilize its expertise).

28 See infra notes 88-157 and accompanying text (reviewing presidential orders and memoranda directing agencies to revisit and sometimes rescind or reverse past actions and agency policy changes and deregulatory actions that followed). For discussions of President Trump's deregulatory attitude and initiatives, see Danielle Ivory \& Robert Faturechi, The Deep Industry Ties of Trump's Deregulation Teams, N.Y. Times, July 12, 2017, at A1 
consistency doctrines and regulatory contingency analysis are of critical importance. If legal norms hold, these presidential requests should lead to far less radical agency actions than sought due to the constraints of statutory language and contingencies that must be engaged. Or, if agencies just acquiesce or follow presidential directions, such agency actions should provoke skeptical judicial review, as has been apparent in initial judicial opinions addressing deregulatory policy shifts. ${ }^{29}$ Due to the uniformity of recent policy change power claims and strategies by President Trump and agencies under his leadership, they likely reveal an intentional effort to recast this body of doctrine to increase room for politicized efforts to revise policy. Or they might reflect a political strategy to push for deregulation that is justified by political gains even if ultimately destined for legal rejection.

Part I introduces standard views about agency policy change authority, reviews recent strong claims about such power made by Justice Gorsuch when he was a circuit court judge, and presents prevalent contrary observations about agency tendencies and expectations of the administrative state. Part I also introduces a substantial sampling of deregulatory actions taken by President Trump and agencies under his supervision, and the claims regarding the policy change authority they reveal. Part II then turns to the web of law governing how and when presidents and agencies can seek policy change. Part III assesses the legality of recent major policy shift proposals and actions, distills through a simplified schematic what agencies seeking to change policy must do, and offers a normative assessment of consistency doctrine. Part IV then reviews categories of agency actions, how consistency doctrine's constraints apply, and why apparent efforts to change this body of doctrine should be met with opposition from both those generally concerned with agency overreach and those worried about imprudent deregulation.

\section{The Regulatory Whim and Policy Change Power Claims}

Claims of agency power to change policy range from matter-of-fact descriptions of agency policy flexibility and responsiveness as the norm, to condemnations of such change as evidence of agency arbitrariness and excessive and unaccountable agency authority. Proposals and orders for agencies to make policy changes also reveal change proponents' claims about such power. This Part introduces such normative and manifested claims about room for agency

(discussing industry ties of teams making deregulatory proposals and potential for conflicts of interest); Eric Lipton \& Danielle Ivory, Trump Says His Regulatory Rollback Already Is the 'Most Far Reaching,' N.Y. TimEs, Dec. 15, 2017, at A16 (summarizing President Trump's goals and deregulatory statements and agencies' many deregulatory actions).

29 See, e.g., Percival, supra note 3, at 2534-35 (discussing New York v. Reilly, 969 F.2d 1147, 1149 (D.C. Cir. 1992), and underlying regulatory history where political pressure for deregulation likely contributed to insufficiently justified regulatory action); see also infra Section II.H (discussing judicial responses to, and frequent rejection of, Trump Administration agency deregulatory policy shifts). 
policy change, with special emphasis on broad recent claims. The Parts that follow question the accuracy of these broad claims of agency power to change policy, explaining how a focus on the contingencies underpinning agency actions melds the cross-cutting requirements and interests held in equipoise by consistency doctrine.

\section{A. The Congressional Expectation of Agency Policy Adjustment}

In most writing about rationales for the modern administrative state, room for policy change and reliance on agencies go hand in hand. Policy change is expected. ${ }^{30}$ Reliance on agencies rather than legislatures or courts to flesh out a body of law is linked to agency expertise and the related need for regulatory learning and adjustment in the development of sound policy. ${ }^{31}$

Legislatures, in contrast, generally lack particular subject matter expertise and cannot enact laws with details sufficient to anticipate complexities and changing circumstances. ${ }^{32}$ Courts are even more generalist in focus and poorly suited to develop policy due to lack of knowledge of broader legal and societal context. ${ }^{33}$ Courts are also often unfamiliar with affected constituencies' practices and concerns, and lack institutional means to gather and assess data and science relevant to a regulatory goal. ${ }^{34}$ In addition, the ways in which webs of law and regulation work together will be known to agencies but seldom understood by legislators or judges. ${ }^{35}$

Agencies are not directly subject to electoral accountability, but they answer to the President and are often held to account by congressional committees. Agencies are also subject to participatory and reason-giving modes of

\footnotetext{
30 See Dotan, supra note 7, at 1031-32 (discussing this expectation).

31 See Peter L. Strauss et al., Gellhorn \& Byse’s Administrative Law: Cases \& COMmENTs 1-50 (9th ed. 2011) (presenting rationales for reliance on agencies).

32 The Third Circuit Court of Appeals explored agency power in the context of an agency adjusting its policies. See FTC v. Wyndham Worldwide Corp., 799 F.3d 236, 243-44, 252 (3d Cir. 2015) (upholding most of FTC's action alleging unfair and deceptive trade practice in setting of lax cybersecurity and discussing agency's subject expertise and policy evolution).

33 See Gillian E. Metzger, Embracing Administrative Common Law, 80 GEO. WASH. L. REV. 1293, 1359-70 (2012) (discussing agencies' expertise and institutional competence in comparison to courts in discussing administrative law's development in common law-like manner).

${ }^{34}$ For a discussion of the relative roles of presidents and agencies in developing policy, but emphasizing congressional delegations to particular agency actors and the expertise-based underpinning of such delegations, see Peter L. Strauss, Overseer or "The Decider"? The President in Administrative Law, 75 GEO. WASH. L. REV. 696, 750-53 (2007).

${ }^{35}$ Id. at 750-52; see also Sidney A. Shapiro, The Failure to Understand Expertise in Administrative Law: The Problem and the Consequences, 50 WAKE ForEST L. REv. 1097, 1099 (2015) (exploring nature of expertise and its underpinning of deference rationales, especially due to pragmatically developed “craft” expertise).
} 
democratic accountability. ${ }^{36}$ Furthermore, neither courts nor legislatures are institutionally capable of implementing and enforcing laws; these two agency tasks result in at least tacit development and revelation of policy. ${ }^{37}$

As a result, agencies will become experts in a delegated field. ${ }^{38}$ They will come to know deeply the web of laws that they are delegated to administer or those that intersect with their turf, plus subsequent implementing regulations, guidance documents, and court decisions. ${ }^{39}$ As repeat players in frequent political contact with congressional committees, the public, and more directly implicated stakeholders, agencies will come to know how various regulatory choices work or could be improved. ${ }^{40}$ In this polycentric and dynamic setting, they will develop a sensitivity to practical complexities and tradeoffs, the interacting players, and regulatory dynamics. ${ }^{41}$ Agencies over time will see how policy choices ripple through the law, linked markets, and underlying protected amenities, such as workplaces, markets, the environment, or educational

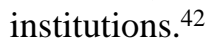

Due to this experience and these interactions, agencies will regularly adjust policy choices based on gained experience or new science or data, even though underlying statutes often remain unchanged. Regulating, under these views, should and ordinarily does involve sequential policy adjustments in light of

${ }^{36}$ See Jerry L. Mashaw, Prodelegation: Why Administrators Should Make Political Decisions, 1 J.L. ECON. \& ORG. 81, 96-99 (1985) (identifying ways agencies are more "responsive" and subject to more accountability and obligations to provide reasons than are legislatures).

${ }^{37}$ Here, the reference to "enforcing" is referring to monitoring and policing compliance with the law, not judicial enforcement of the law through a court decision.

38 See generally Shapiro, supra note 35 (discussing functioning and creation of agency expertise).

39 Gillian E. Metzger, The Constitutional Duty to Supervise, 124 YALE L.J. 1836, 1843 (2015) (analyzing constitutional duty to supervise and discussing courts' lack of accountability and expertise compared to agencies).

40 See Wendy E. Wagner, A Place for Agency Expertise: Reconciling Agency Expertise with Presidential Power, 115 Colum. L. REV. 2019, 2026-27 (2015) (observing that “multiple, overlapping public and scientific processes constrain the agencies' discretion and improve the rigor and transparency of their decisions" and seeing benefits in this " deliberative approach" and how it subjects regulatory science claims to "rigorous questioning and constant, skeptical double-checking”).

41 Jeffery A. Pojanowski, Reason and Reasonableness in Review of Agency Decisions, 104 NW. U. L. REV. 799, 849 (2010) (discussing polycentric policymaking and link to deference regimes).

42 See Shapiro, supra note 35, at 1140 (stating that due to "cacophony of inputs," "regulatory governance" by agencies requires them to "rely on craft expertise to arrive at satisfactory solutions to the regulatory problems that [they are] addressing”). 
pragmatic learning and efforts to better achieve statutory goals. ${ }^{43}$ Political leanings and changing attitudes about regulations, often due to changes in presidential administrations, will further influence what political appointees heading agencies view as "better" or in need of change. ${ }^{44}$ What must accompany such attempted changes, however, is a separate issue discussed below.

Analysts of the modern administrative state often divide into two opposed camps that clash in their sentiments about agency policy change authority. Regulatory skeptics often characterize agencies as tending to engage in overreach and excess in the form of expansive claims of power or too-frequent policy shifts. ${ }^{45}$ At the other end of the spectrum, many students of regulation highlight a near opposite set of problems, instead seeing agencies as tending more to inertia, neglect of newly emergent risks and areas of shared or uncertain regulatory turf, inaction in assessing the efficacy of old regulations, or craven deregulation due to capture or political pressure. ${ }^{46}$ These fundamental disagreements about regulatory proclivities lead to clashing policy prescriptions about the need to chill or encourage agency activity.

Thus, despite disagreements about the value of regulation and the administrative state, the reality of at least some agency power to make policy changes should be a source of little consternation. Recent claims and actions, however, reveal dramatically different and changing views about agency power to change policy.

\section{B. The Justice Neil Gorsuch Regulatory “Whim” Theory}

Justice Neil Gorsuch, while on the Tenth Circuit, was far from sanguine about agency power to change policy. As a circuit court judge, he wrote several opinions that, in no uncertain terms, saw agency policy change as an extreme and constitutionally problematic power, especially if that agency shift followed some earlier judicial policy exegesis. ${ }^{47}$ And, in his rhetoric, his condemnation of agency power to change policies closely echoed broader condemnations of the

43 See Sidney A. Shapiro \& Robert L. Glicksman, Risk Regulation at RisK: Restoring A Pragmatic Approach 14-30 (2003) (exploring prevalence and benefits of pragmatic learning in regulation).

${ }^{44}$ The persistent question of limitations or constraints on such politicized oversight and control is a strain analyzed throughout this Article. See infra Section II.C, Part IV (describing such constraints).

45 See Daryl J. Levinson, Empire-Building Government in Constitutional Law, 118 HARV. L. REV. 915, 923-37 (2005) (questioning agencies' desire and ability to engage in overreach).

46 See infra Section I.C (discussing problem of regulatory “inertia”).

${ }^{47}$ See, e.g., Gutierrez-Brizuela v. Lynch, 834 F.3d 1142, 1149-58 (10th Cir. 2016)

(Gorsuch, J., concurring); De Niz Robles v. Lynch, 803 F.3d 1165, 1172 (10th Cir. 2015) (rejecting retroactive application of agency interpretation because it represented executive attempt to wield legislative power without traditional limitations on scope of legislative action); United States v. Nichols, 784 F.3d 666, 667-77 (10th Cir. 2015) (Gorsuch, J., dissenting from the denial of rehearing en banc) (arguing for reinvigoration of nondelegation doctrine). 
administrative state and regulation heard from anti-regulatory think-tanks and others calling for reform of the world of regulation. ${ }^{48}$

Then-Court of Appeals Judge Gorsuch condemned an order of the Board of Immigration Appeals and the underlying policy shift regarding the immigrant status it reflected. ${ }^{49}$ But he also used the case as a vehicle to condemn more broadly agency policy inconsistency. In his majority opinion, he wrote that an agency can "exploit a gap in the statute to implement its own (continuously revisable) policy-influenced vision of what the law should be." 50 He alludes to the risk that an agency will retroactively shift policy based on "shifting political winds." ${ }^{11}$ Further, he sees a broad risk that agency latitude to shift policies, even when earlier court precedents exist, means that agencies can "impos[e] ... uncertainty on an entire class of persons with significant interests at stake." 52

In an unusual concurrence to his own majority opinion, now-Justice Gorsuch writes in even broader strokes, characterizing the leading deference and consistency cases as permitting agencies to "swallow huge amounts of core judicial and legislative power and concentrate federal power in a way that seems [hard] to square with the Constitution of the framers' design." 53 He suggests it may be time to "face the behemoth." 54

48 See, e.g., Raymond M. Kethledge, Ambiguities and Agency Cases: Reflections After (Almost) Ten Years on the Bench, 70 VAND. L. REV. En BANC 315, 323-24 (2017) (reviewing reasons why the federal judge-author finds Chevron deference problematic, especially ambiguity claims by agencies to "support the policy result that the agency wants to reach" that are akin to "judicial activism" and "arrogation" of power by agencies and agencies' "palpable sense of entitlement" due to deferential review); Christopher J. Walker, Attacking Auer and Chevron Deference: A Literature Review, 16 Geo. J.L. \& PuB. PoL'Y 103, 104 (2018) (reviewing jurisprudence and scholarship criticizing deference regimes). Some offer a more journalistic and overtly anti-regulatory critique. See, e.g., Iain Murray, Stopping the Bureaucrats Requires an End to Chevron Deference, NAT’L REV. (May 11, 2016, 6:53 PM), https://www.nationalreview.com/corner/stop-bureaucrats-ending-chevron-deferencethrough-sopra/ [https://perma.cc/FH6V-4X6Y]; see also infra Section I.C (further citing and discussing such concerns). For a critique focused on the applied indeterminacy and manipulability of Chevron deference, and suggesting a return to pre-Chevron deference regimes, see Jack M. Beermann, End the Failed Chevron Experiment Now: How Chevron Has Failed and Why it Can and Should be Overruled, 42 ConN. L. Rev. 779 (2010).

${ }^{49}$ Gutierrez-Brizuela, 834 F.3d at 1150 ("If [the order] doesn't qualify as an unconstitutional revision of a judicial declaration of the law by a political branch, I confess I begin to wonder whether we've forgotten what might.”).

${ }^{50}$ Id. at 1146 n.1 (majority opinion).

51 Id. at 1146.

52 Id. at 1147. The Tenth Circuit here is parsing the logic and consequences of the intersection of several major cases that together generally give agencies room to choose procedural modes and adjust policy. See id. Those cases are introduced and analyzed later is this Article. See infra Section II.B.

53 Gutierrez-Brizuela, 834 F.3d at 1149 (Gorsuch, J., concurring).

${ }^{54}$ Id. 
After parsing deference doctrine, he makes his strongest assertions about agency power to vacillate, linking policy change power to the risk of agencies "exploit[ing] ambiguous laws...f for their own prerogative." 55 He says regulatory stakeholders "must always remain alert to the possibility that the agency will reverse its current view 180 degrees anytime based merely on the shift of political winds and still prevail." ${ }^{56} \mathrm{He}$ says that agencies may do so based on "their own preferences about optimal public policy when a statute is ambiguous." ${ }^{77}$ Or, even more strongly, he says an agency can seek "to pursue whatever policy whim may rule the day."58

The claimed risk of day-to-day vacillation is a repeated theme, with Justice Gorsuch stating that "an agency can enact a new rule of general applicability affecting huge swaths of the national economy one day and reverse itself the next" and a few lines later repeats the "reverse itself the next day" claim. ${ }^{59}$ Later, he returns to the "whim" theme, reading the Chevron case as permitting "agencies to upset the settled expectation of the people by changing policy direction depending on the agency's mood at the moment." 60 He suggests de novo judicial review of a law's meaning as a way to provide assurance to the public or those regulated that "the rug will not be pulled from under them tomorrow, the next day, or after the next election."61

In this discussion, Justice Gorsuch relies on cases and case language with little attention to the underlying agency procedural mode or which framework and presumptions apply in which settings. ${ }^{62}$ Most of his cases and framework discussion err if they reflect an assumption that an agency policy generated via informal adjudication is governed by Chevron. This isn't impossible, but after United States v. Mead Corp., ${ }^{63}$ quasi-democratic participatory methods are

${ }^{55}$ Id. at 1152.

${ }^{56} I d$.

${ }^{57} \mathrm{Id}$.

${ }^{58}$ Id. at 1153. Four Supreme Court dissenters articulated a somewhat similar concern with policy change based on "regulatory whim," but argued that it is not permissible and advocated for a narrow reading of new Court language about such power. See FCC v. Fox Television Stations, Inc., 556 U.S. 502, 552 (2009) (Breyer, J., dissenting) ("Where does, and why would, the APA grant agencies the freedom to change major policies on the basis of nothing more than political considerations or even personal whim?”).

${ }^{59}$ Gutierrez-Brizuela, 834 F.3d at 1154.

60 Id. at 1158.

61 Id.

62 Professor Dotan correctly suggests that procedural modes do and must shape judicial review of agency policy changes. See Dotan, supra note 7, at 1062 ("The procedural approach acknowledges the relative advantage that agencies have over courts in terms of professionalism and democratic accountability.”).

63533 U.S. 218 (2001). 
generally the antecedent to agency ability to rely on the Chevron deference framework. ${ }^{64}$

Still, now-Justice Gorsuch seems to read doctrine to at least tempt agencies to make abrupt, whim-based policy changes and sees agencies as likely to abuse such power. He makes virtually no mention of how statutory choices, facts, agency reasoning, or current doctrine might already check such claimed agency power. ${ }^{65}$ As explained below, this is a major omission that perhaps explains these overly broad claims. ${ }^{66}$

\section{The Ossification and Agency Inertia Theories}

It is hard to reconcile these views about agency power, especially their alleged tendency to act on a "whim" and create uncertainty by changing policy day-today, with the realities of onerous modern notice-and-comment rulemaking. They also run counter to most studies of actual agency behavior and agency proclivities. A prominent opposing normative and empirical claim is that agencies change policy too infrequently. Federal Register notices, especially final rules, are often lengthy and engage with massive rulemaking records. Major regulations typically follow years of work and include dozens or hundreds of pages of "preamble" explanation plus often additional referenced analysis and comment responses. ${ }^{67}$ And because promulgated regulations announcing a policy shift require notice, receive a wave of comments, and end with lengthy

\footnotetext{
${ }^{64}$ Mead itself calls for courts to analyze if Congress has given the agency power to act with the "force of law" and identifies legislative requirements of procedural formality and use of procedures like notice-and-comment rulemaking or formal agency adjudication as ordinarily a prerequisite for Chevron deference. Id. at 229-31; see also Daniel A. Farber \& Anne Joseph O’Connell, The Lost World of Administrative Law, 92 TEX. L. REV. 1137, 117172 (2014) (discussing usual procedural prerequisites for agency claims of deference after Mead).

65 Some of then-Judge Gorsuch's rhetoric seems focused upon National Cable \& Telecommunications Association v. Brand X Internet Services, 545 U.S. 967 (2005), and how it allows an agency to interpret a statute differently than an earlier judicial construction. That case, however, is more about the contours and logic of Chevron deference following an earlier judicial interpretation of a statutory provision than an important precedent about conditions shaping and constraining an agency's ability to make a shift in its own policies.

66 Then-Judge Gorsuch's powerful anti-regulatory and anti-Chevron deference language did garner notice and support among anti-regulatory scholars. See, e.g., Ilya Somin, Gorsuch Is Right About Chevron Deference, WASH. Post (Mar. 25, 2017), https://www.washington post.com/news/volokh-conspiracy/wp/2017/03/25/gorsuch-is-right-about-chevrondeference/?noredirect=on\&utm_term=.12429b0ec632 (noting Justice Gorsuch’s opinion and agreeing with its anti-regulatory underpinnings).

${ }^{67}$ For example, the EPA's Clean Power Plan (“CPP”) rule was issued with a Federal Register preamble of 459 pages, plus accompanying memoranda on legal issues, empirical studies, and responses to particular comments. Carbon Pollution Emission Guidelines for Existing Stationary Sources: Electric Utility Generating Units, 80 Fed. Reg. 64,662 (Oct. 23, 2015) (to be codified at 40 C.F.R. pt. 60).
} 
agency responses and explanations for their choices, regulations (whether new or policy shifts) neither come as surprise to anyone, nor emerge in anything remotely resembling a "day" or as a result of "whim."68 As noted in recent scholarship, when agencies have failed to utilize participatory deliberative procedures, they have triggered significant Supreme Court rejections even when the actions were linked to presidents' preferences. ${ }^{69}$

Relatedly, the literature on the nature and roots of regulatory "ossification" clashes with Justice Gorsuch's claims. ${ }^{70}$ Due to rigorous procedural and explanation requirements imposed by courts, presidents, and Congress, especially under modern "hard look review," rulemaking tends to be a slow process involving massive documentation and written justification. ${ }^{71}$

And if one digs deeper, especially into "new governance" and democratic experimentalism literature, but also into literature on regulatory slippage, the regulatory commons, and rulemaking "ruts," one finds yet more contradiction of the abrupt whim-based change claim. ${ }^{72}$ Likewise, calls for agencies to

68 For Justice Gorsuch’s “whim” and day-to-day change claims, see supra Part I.B.

69 Lisa Schultz Bressman, Deference and Democracy, 75 Geo. WASH. L. REV. 761, 78990 (2007) (arguing that despite Chevron's discussion linking deference to agency political accountability through Presidents' electoral accountability, more recent cases reject actions where agencies "acted undemocratically" without opportunities for public input and where statutory cues raised authority questions).

${ }^{70}$ Ossification theory posits that demanding judicial review of agency action and other analytical hurdles imposed by statutes and executive orders lead agencies to engage in slow work, produce massive, detailed explanations, and even dissuades agencies from beginning rulemakings. See, e.g., Thomas O. McGarity, Some Thoughts on Deossifying the Rulemaking Process, 41 DuKE L.J. 1385, 1462 (1992) (blaming judicial and political reversals for ossification); Richard J. Pierce, Jr., Two Problems in Administrative Law: Political Polarity on the District of Columbia Circuit and Judicial Deterrence of Agency Rulemaking, 1988 DuKE L.J. 300, 300-02 (explaining causes and effects of agency ossification). Compare Jacob Gersen \& Adrian Vermeule, Thin Rationality Review, 114 Mich. L. REV. 1355, 1357-59, 1369 (2016) (questioning ossification thesis and arguing for less rigorous judicial review of agency reasoning), and Jason Webb Yackee \& Susan Webb Yackee, Testing the Ossification Thesis: An Empirical Examination of Federal Regulatory Volume and Speed, 1950-1990, 80 GEO. WASH. L. REV. 1414, 1481-82 (2012) (questioning ossification thesis), with Richard J. Pierce, Jr., Rulemaking Ossification Is Real: A Response to Testing the Ossification Thesis, 80 GEO. WASH. L. REV. 1493, 1503 (2012) (arguing despite Professors Yackees' research that ossification remains pervasive phenomenon), and Catherine M. Sharkey, Cutting in on the Chevron Two-Step, 86 FordHAM L. Rev. 2359, 2420-21 (2018) (reading recent Supreme Court cases as invigorating judicial scrutiny and questioning claims of Gersen and Vermeule).

${ }^{71}$ See McGarity, supra note 70, at 1419-20 (stating that because "reviewing courts are inconsistent in the degree to which they are deferential, [agencies] are constrained to prepare for the worst-case scenario on judicial review," leading to "resource-intensive and timeconsuming” work).

72 See, e.g., Lynn E. Blais \& Wendy E. Wagner, Emerging Science, Adaptive Regulation, and the Problem of Rulemaking Ruts, 86 TEX. L. REV. 1701, 1711-15 (2008) (discussing problem of long-unamended regulations); William W. Buzbee, Recognizing the Regulatory 
undertake "regulatory lookback" are rooted in concerns, often by anti-regulatory advocates, that old policies live on and on, causing confusion and hindering beneficial societal or market change. ${ }^{73}$

These somewhat overlapping bodies of scholarship document problems of agency inaction, failure to update and improve policy, and agency reluctance to act. Instead of "empire" building, turf expansion, or overly frequent policy shifts, these empirical, historical, and sometimes theoretical explorations end up identifying the opposite problem. ${ }^{74}$ They identify such problems, then suggest means to overcome pervasive problems of agency inertia, inaction, and frozen law. ${ }^{75}$

\section{Agency Overreach Concerns and the "Major Questions" Canon}

Nonetheless, in calls for regulatory reform, critics of the administrative state often assert a similar mixed claim of agency overreach, concern with agency actions based on whim or mere political preferences, and regret that deregulatory policy change is not easier. ${ }^{76}$ Senator Orrin Hatch, for example, supported a regulatory reform bill with claims of regulatory excess and by characterizing

Commons: A Theory of Regulatory Gaps, 89 IowA L. REV. 1, 5-6 (2003) (identifying as "regulatory commons" challenges settings where multiple jurisdictions or entities have potential regulation over one issue, identifying areas of missing regulation, and analyzing incentives for potential regulators to leave social ills unaddressed); Michael C. Dorf \& Charles F. Sabel, A Constitution of Democratic Experimentalism, 98 CoLuM. L. REV. 267, 297-98 (1998) (identifying problems of rigidified law and regulation, and arguing for benefits of continuous generation of new information and adjustment and improvement in array of legal areas); Daniel A. Farber, Taking Slippage Seriously: Noncompliance and Creative Compliance in Environmental Law, 23 HARV. EnvTL. L. ReV. 297, 304 (1999) (discussing delay among other forms of agency "slippage”); Levinson, supra note 45, at 956-57 (challenging theory anticipating agency empire building and explaining why contrary proclivities are more likely).

73 See Cass R. Sunstein, The Regulatory Lookback, 94 B.U. L. REV. 579, 588-96 (2014) (describing arguments for regulatory lookback and extent to which it already occurs).

74 See Levinson, supra note 45 (discussing and criticizing "empire building” thesis); see also Marissa Martino Golden, What Motivates Bureaucrats? Politics and AdMinistration DuRing the REAGAN YEARs 151-72 (2000) (questioning "rational actor" theory expectations of self-interested agency official behavior resulting in shirking and budget maximization, and observing "hunkering down," "compliant," and "cooperative” interactions between anti-regulatory political appointees and agencies’ top career officials).

75 See, e.g., Michael A. Livermore \& Richard L. Revesz, Regulatory Review, Capture, and Agency Inaction, 101 GEO. L.J. 1337, 1337 (2013) (identifying agency inaction as consequence of capture and suggesting solutions for limiting instances of such inaction).

${ }^{76}$ Some scholars suggest that greater presidential and political involvement could rectify several of these problems. See Levin, supra note 16, at 555 (reading FCC v. Fox Television Stations, Inc. as allowing for greater agency policy latitude after elections and calling this "salutary" development); Watts, supra note 17, at 7-9 (supporting greater acceptance of politics' place in regulatory decisionmaking, subject to respect for statutory constraints and facts). 
Chevron deference as a disappointingly failed strategy to shield deregulatory efforts from judicial rejection. ${ }^{77} \mathrm{He}$ stated that "experience has ... seriously undermined the conservative case for Chevron deference," especially past hopes that through Chevron, a "conservative administration would be able to administratively roll back the federal regulatory burden." 78

Similarly, defenders of the Office of Information and Regulatory Affairs ("OIRA"), which supervises regulatory cost-benefit analyses pursuant to executive orders, see OIRA and such analyses as a valuable check on regulatory excess. ${ }^{79}$ But regulatory power, rationality, stringency, and policy shifts or vacillations are distinct phenomena. They raise different concerns and are subject to somewhat different doctrinal and political constraints.

Still, one doctrinal strain regarding agency change includes rhetoric and underlying concerns that, in their normative leaning, are fairly consistent with Justice Gorsuch's indictment of agencies and regulation. This discussion is in the line of Supreme Court cases setting forth the "major question" and "power" canons. ${ }^{80}$ These deference-neutralizing canons of interpretation so far have been triggered by agency actions involving the confluence of a changed or new assertion of regulatory power, major economic impacts, and other statutory signals casting doubt on the logic and legality of a power claim which is usually also a policy shift. ${ }^{81}$ Justice Scalia's majority opinion in Utility Air Regulatory

77 The Second Hoover Commission's 60th Anniversary, Hoover Inst. (Mar. 16, 2016), https://www.hoover.org/events/second-hoover-commissions-60th-anniversary

[https://perma.cc/6TNM-V3SS] (containing comments of Sen. Orin Hatch at around 3:40:30).

${ }^{78} \mathrm{Id}$.

79 The literature on OIRA and cost-benefit analyses is now massive. For two recent countervailing perspectives, compare Cass R. Sunstein, The Office of Information and Regulatory Affairs: Myths and Realities, 126 HARV. L. REV. 1838, 1840-41 (2013), in which a former head of OIRA explains and defends OIRA's role and importance of cost-benefit analysis, with Frank Ackerman \& Lisa Heinzerling, Priceless: On KNowing the Price OF EVERYthing AND the VAlue OF Nothing 91-122 (2004), which highlights the manipulability of cost-benefit analysis and questions its legality and morality.

80 See Lisa Heinzerling, The Power Canons, 58 WM. \& MARY L. REv. 1933, 1933 (2017) (arguing that Supreme Court's decisions in Utility Air Regulatory Group v. EPA, King v. Burwell, and Michigan $v$. EPA created new trio of canons of statutory interpretation which together "not only rearrange the Chevron-dominated relationship between the courts and administrative agencies; [but they] also realign the relationship between the courts and Congress").

81 See, e.g., Nat'l Fed'n of Indep. Bus. v. Sebelius, 567 U.S. 519, 543-46 (2012) (declining to defer to Internal Revenue Service regulation and judicially resolving question of statutory power due to contextual indications that there was no intent to grant such extensive power to agency); FDA v. Brown \& Williamson Tobacco Corp., 529 U.S. 120, 160 (2000) (declining to afford usual Chevron deference to FDA regulation categorizing tobacco as drug due to conclusion that "Congress could not have intended to delegate a decision of such economic and political significance to an agency in so cryptic a fashion”); MCI Telecomm. Corp. v. Am. Tel. \& Tel. Co., 512 U.S. 218, 231 (1994) (discussing Chevron and finding it "highly 
Group v. EPA 82 (“UARG”) reads most like Justice Gorsuch's concurrence, especially in its blistering language criticizing the EPA as unlawfully "seizing expansive power" by claiming new authority to regulate thousands of air pollution sources. ${ }^{83}$ And UARG was itself substantially based on language in FDA v. Brown \& Williamson Tobacco Corp. ${ }^{84}$ which rejected the FDA's new foray into regulation of tobacco products. 85

However, while these cases often condemn particular agency claims of power to change policy or reach new targets of regulation, these Supreme Court opinions do so en route to rejecting the agency power claims. ${ }^{86}$ Thus, while Justice Gorsuch as a judge assumed agencies under existing doctrine could get away with major self-serving policy shifts or actions based on a "whim," the Supreme Court in the "major questions" cases has rejected such shifting agency claims of power and also reduced or eliminated deferential reviewing frames in such settings. Litigants opposed to regulation rely heavily on this line of cases. ${ }^{87}$

unlikely" that Congress would entrust "essential characteristic" of statutory scheme to agency discretion).

82134 S. Ct. 2427 (2014).

${ }^{83}$ Id. at 2444.

84529 U.S. 120 (2000).

${ }^{85}$ Id. at 160-61; see Util. Air Regulatory Grp., 134 S. Ct. at 2444 (quoting Brown \& Williamson, 529 U.S. at 159). Professor Sharkey reads these cases, as well as Michigan v. EPA and Encino Motorcars, as revealing an appropriate Supreme Court move towards a form of Chevron Step Two review that incorporates the rigorous factual, responsiveness, and reasoning scrutiny required by State Farm and other cases articulating the requirements of "hard look review" and "reasoned decisionmaking." Sharkey, supra note 70, passim; see also William W. Buzbee, Preemption Hard Look Review, Regulatory Interaction, and the Quest for Stewardship and Intergenerational Equity, 77 GEO. WASH. L. REV. 1521, 1547-80 (2009) (finding Supreme Court review of agency claims of preemptive impact to resemble closely hard look review, especially in seeking agency engagement with and justification grounded in facts); infra Sections II.B, II.C, II.E (discussing these cases, their doctrinal overlap, and rigorous engagement they require of agencies making policy change).

86 The Court in UARG stated that the "EPA's interpretation is also unreasonable because it would bring about an enormous and transformative expansion in EPA's regulatory authority without clear congressional authorization. When an agency claims to discover in a long-extant statute an unheralded power to regulate 'a significant portion of the American economy,' ... we typically greet its announcement with a measure of skepticism.” Util. Air Regulatory Grp., 134 S. Ct. at 2444 (quoting Brown \& Williamson, 529 U.S. at 159).

${ }^{87}$ For example, in litigation opposing Obama Administration regulation of greenhouse gas emissions, challengers relied heavily on this same blend of the "major questions" canon, claims of abrupt agency changes in statutory interpretation that also resulted in expanded agency power, and claims of massive economic impacts. See generally LINDA TSANG \& Alexandra M. Wyatt, Cong. Research Serv., R44480, Clean Power Plan: Legal Background and Pending Litigation in West Virginia V. EPA (2017) (describing underlying regulation and court challenges). 


\section{E. The Trump Administration and Embrace of Change Power}

Early proposals and actions by the Trump Administration, especially in the environmental law arena, reflect a broad claim of presidential and agency power to reverse course with little constraint. As of mid-2018, policy change orders, directives, proposals, or actions have overwhelmingly been in a deregulatory direction. Few have completed the regulatory process or been reviewed in the courts, but the proposals reveal the Administration's view of policy change power.

Under the Trump Administration, most agencies announcing policy change proposals or actions have offered little legal analysis, usually just referring to the result sought or quoting language acknowledging the role of politics in regulation and room for policy change. ${ }^{88}$ Presidential and executive policy shift proposals, as initiated by agencies, have reflected little effort to satisfy the conditions constraining such change. ${ }^{89}$ Most of these policy change actions or proposals have included minimal engagement with what this Article collectively labels "contingencies," namely facts underlying earlier regulatory policies and the accompanying reasoning of earlier actions. This Part reviews such power claims. Later Parts critique their legal validity under governing doctrine and illuminate the legal importance of contingencies shaping past actions and proposed changes. ${ }^{90}$

\section{The Two-for-One Executive Order}

The largest scale action by the Trump Administration calling for agency policy changes is the "two-for-one" executive order. In Executive Order 13,771, President Trump "ordered" agencies, as a "policy of the executive branch," to accompany any new regulation with identification of "two prior regulations ... for elimination."91 The only exception provided was if such

88 See infra Section II.C.

89 See infra notes 102-111 and accompanying text (discussing recent policy shift proposals justified on grounds that agencies lack power previously asserted, and noting how FCC has been more thorough on issues of law and fact than other executive agencies during the Trump Administration).

90 With both chambers of Congress and the presidency in the same party's hands, Congress passed, and President Trump signed, fifteen Congressional Review Act resolutions invalidating late Obama Administration regulations. See Thomas O. McGarity, The Congressional Review Act: A Damage Assessment, Am. РRospect (Feb. 6, 2018), http://prospect.org/article/congressional-review-act-damage-assessment [https://perma.cc/G6K2-JKQF] (reviewing invalidations and their impacts). Because these involved a form of legislative action, they are not discussed here despite their major deregulatory impact.

91 Exec. Order No. 13,771, 82 Fed. Reg. 9339, 9339 (Feb. 3, 2017). 
elimination is "prohibited by law."92 In addition, agency actions are to result in no increased regulatory costs and new regulations must to be "offset by the elimination of existing costs associated with at least two prior regulations." 93 Thus, the President directed all agencies to make deregulatory policy shifts, but without regard to the net benefits, legislative edicts, and societal conditions that led to the earlier regulatory actions. Nothing in the Order's text, apart from typical executive order boilerplate language about respect for other legal requirements and prohibitions, called for rigorous engagement with relevant law, facts, and earlier reasoning.

Due to the Order's asymmetry and lack of attention to the benefits of earlier regulation, let alone analysis of net regulatory costs or benefits, a broad coalition filed suit alleging that Executive Order 13,771 could never be followed in compliance with the law and would unavoidably taint all agencies' actions. ${ }^{94}$ That initial challenge, made before any agency had completed actions in compliance with the Order's edicts that could be traced to particularized palpable effects, was dismissed on standing grounds despite the deciding judge's critical comments and observations about the Order's effects, legality, and logic. ${ }^{95}$ OIRA refined the Order's skewed requirements, but still largely followed the President's mandates. ${ }^{96}$

92 Id. Section 5 of the order adds that it should not "be construed to impair or otherwise affect: (i) the authority granted by law to an executive department or agency" and notes that it "shall be implemented consistent with applicable law.” Id. at 9340.

93 Id. at 9339 .

94 Complaint for Declaratory and Injunctive Relief at 5, Public Citizen, Inc. v. Trump, 297 F. Supp. 3d 6 (D.D.C. 2018) (No. 17-cv-00253) ("Rulemaking in compliance with the Executive Order's '1-in, 2-out' requirement cannot be undertaken without violating the statutes from which the agencies derive their rulemaking authority and the Administrative Procedure Act ([“]APA[”]).”). The plaintiffs detail their theory regarding the order's illegality in their Motion for Summary Judgment. Plaintiffs' Motion for Summary Judgment at 2, Pub. Citizen, Inc., 297 F. Supp. 3d 6 (No. 17-cv-00253).

${ }^{9}$ Pub. Citizen, Inc., 297 F. Supp. 3d at 20-22, 27 (dismissing for lack of standing mostly due to inability to trace particular harms to any potential future resulting actions or foregone actions, but also noting delay that will result and pointing out puzzling logic of assessing costs without regard to benefits).

${ }^{96}$ Memorandum from Dominic J. Mancini, Acting Adm’r, Office of Info. \& Regulatory Affairs, Interim Guidance Implementing Section 2 of the Executive Order of January 30, 2017, Titled "Reducing Regulation and Controlling Regulatory Costs" (Feb. 2, 2017), https://www.whitehouse.gov/the-press-office/2017/02/02/interim-guidance-implementingsection-2-executive-order-january-30-2017 [https://perma.cc/DS7K-URS3] (reviewing order and providing guidance on agency compliance, but repeatedly mentioning only "costs" without reference to "benefits" or "net benefits"). An OIRA memorandum setting forth agency obligations to prepare their regulatory agenda for the coming year alluded to the order, but in a few places also mentioned costs and benefits, although not in direct reference to that order's instructions. See Memorandum from Neomi Rao, Adm'r, Office of Info. \& Regulatory Affairs, Data Call for the Fall 2017 Regulatory Plan and Unified Agenda of Federal Regulatory and Deregulatory Actions 1, 8 (Aug. 18, 2017) (quoting “cost” language of order 


\section{The Agency Stay and Delay Two-Step}

Numerous agencies pursued a two-step process to render inoperative existing regulations, often with a promise of some future replacement. ${ }^{97}$ In Federal Register notices and briefs, agencies referenced some future anticipated or possible policy change, but, in the meantime, sought to stay, suspend, and not implement pending regulations, or through similar language or strategies proposed to render an already finalized regulation a nullity. Here too, agencies or their attorneys cited cases mentioning presidential powers and acknowledging that agencies can seek policy change, but without attention to other requirements. ${ }^{98}$ As detailed and analyzed below, because these agencies did not yet seek to replace or justify the abandonment of the earlier regulation, but were effectively rendering it a nullity, reviewing courts during 2017 and 2018 overwhelmingly rejected such a strategy. ${ }^{99}$

\section{Splintering Deregulatory Steps}

In other settings, Trump Administration agencies took initial steps to undo a regulation, but divided up the steps to getting there and, because of this division, sought to limit comments on the legality or overall wisdom of the earlier regulations' choices or some future change. ${ }^{100}$ It is not yet clear if agencies in future finalized policy shifts will be attentive to the contingencies and antecedent regulatory actions in justifying some new policy. ${ }^{101}$

\section{Agency Statutory Abnegation Claims}

Numerous agencies' policy reversals were quite summary, relying on what this Article calls "agency statutory abnegation" claims: the agencies newly claim

and mentioning agency assessment of both "costs and benefits," but in connection with another applicable order, Executive Order 12,866).

97 See Lisa Heinzerling, Unreasonable Delays: The Legal Problems (So Far) of Trump's Deregulatory Binge, 12 HARV. L. \& POL'Y REV. 13, 16-47 (2018) (describing array of stay and delay type of actions, judicial rejections, and analyzing such actions' legality); Jennifer Dlouhy \& Alan Levin, Trump Tests Legal Limits by Delaying Dozens of Obama's Rules, BLOOMBERG (July 13, 2017 4:00 AM), https://www.bloomberg.com/news/articles/2017-0713/trump-tests-legal-limits-by-delaying-dozens-of-obama-s-rules (identifying rules proposed for delay, stay, or non-enforcement); infra Section II.H (introducing and analyzing several of these actions).

98 See generally Heinzerling, supra note 97 (discussing and analyzing such actions' legality); infra Section II.H (discussing further such postponement, delay actions, and judicial rejections).

99 See infra Section II.H (analyzing recent decisions).

100 See infra Sections II.H, III.B (assessing some of Trump Administration's deregulatory efforts).

101 One finalized action delaying the "applicability date” of the Clean Water Rule still omits such analysis. See infra Section III.B (discussing Clean Water Rule and related divided deregulatory steps). 
that they lack power previously asserted, and state that this new reading of the law requires a policy reversal. Agencies have occasionally used such a strategy in the past, most famously in the EPA actions during the George W. Bush Administration leading to Massachusetts v. EPA, but it also appears in other decisions. ${ }^{102}$ Its use exploded during 2017 and 2018. ${ }^{103}$ A few examples are reviewed here.

102 See Mineral Policy Ctr. v. Norton, 292 F. Supp. 2d 30, 35, 41-43, 45 \& n.18, 50-51 (D.D.C. 2003) (noting agency disclaiming power previously asserted, concluding one such view by Interior Department Solicitor was in error, though it was not adopted in final agency action, while another claim of no legal power over "unclaimed lands" was in error and required judicial rejection); supra note 8 and infra notes 215-224 and accompanying text (discussing Massachusetts v. EPA).

103 During 2017 and 2018, many agency proposals and actions relied in whole or in part on claims of statutory abnegation. See, e.g., Repeal of Carbon Pollution Emission Guidelines for Existing Stationary Sources: Electric Utility Generating Units, 82 Fed. Reg. 48,035, 48,037 (proposed Oct. 16, 2017) (to be codified at 40 C.F.R. pt. 60) (proposing to repeal Clean Power Plan); infra notes 133-146 and accompanying text (discussing Clean Power Plan and actions taken to repeal it, including new interpretation of statute and claim of lack of power to regulate as claimed in 2015); infra notes 113-132 and accompanying text (discussing several divided steps taken to delay or abandon Clean Water Rule and proposing to adopt plurality opinion view of Justice Scalia that would substantially change and limit federal authority). Statutory abnegation was also a substantial element of many other policy change actions. Take, for example, the Deferred Action for Childhood Arrivals ("DACA") Program. See Regents of the Univ. of Cal. v. U.S. Dep’t of Homeland Sec., 279 F. Supp. 3d 1011, 102223 (N.D. Cal. 2018) (reviewing history of DACA); infra notes 353-365 and accompanying text. There are yet more examples in the EPA context. See Memorandum from William L. Wehrum, Assistant Adm'r, Envtl. Prot. Agency on Reclassification of Major Sources as Area Sources Under Section 112 of the Clean Air Act to Reg'l Air Div. Dir. 2-3 (Jan. 25, 2018), available at https://www.epa.gov/stationary-sources-air-pollution/reclassification-majorsources-area-sources-under-section-112-clean [https://perma.cc/BYP4-ST7Q] (abandoning twenty-two year old EPA view of when sources are subject to hazardous air pollutant regulation and calling previous policy "contrary to the plain language" of statute in using temporal variable that made old policy "once in, always in”). For analysis of the shift described in the Wehrum memorandum, see Michelle West, “Once In, Always In" Now Out: How the EPA Is Reducing Regulations on Hazardous Air Pollutant Emitters, GeO. ENVTL. L. REV. (Mar. 3, 2018), https://gelr.org/2018/03/03/once-in-always-in-now-out-how-the-epa-isreducing-regulations-on-hazardous-air-pollutant-emitters/ [https://perma.cc/E98G-33WK], which notes that the EPA's new take on the "once in, always in" policy "will likely result in a remand, if and when it is challenged."

There are still more EPA examples. See, e.g., Repeal of Emission Requirements for Glider Vehicles, Glider Engines, and Glider Kits, 82 Fed. Reg. 53,442, 53,443 (proposed Nov. 16, 2017) (to be codified at 40 C.F.R. pts. 1037, 1068) (proposing to reverse earlier policy that regulated air emissions from refurbished trucks and engines known as "gliders" and claiming that EPA had no such authority under language in Clean Air Act). The Department of Labor has also engaged in this practice. Tip Regulations Under the Fair Labor Standards Act (“FLSA”), 82 Fed. Reg. 57,395, 57,399 (Dec. 5, 2017) (proposing to abandon previous regulation regarding tips policy, claiming that agency had earlier misinterpreted extent of its 
In the immigration arena, the Department of Homeland Security ended the Temporary Protected Status ("TPS") of citizens of two foreign nations. ${ }^{104}$ In those actions, however, the Department of Homeland Security not only changed

statutory authority). The Department of Agriculture has engaged in this practice as well. National Organic Program ("NOP”); Organic Livestock and Poultry Practices-Withdrawal, 82 Fed. Reg. 59,988, 59,988-90 (proposed Dec. 18, 2017) (to be codified at 7 C.F.R. pt. 205) (proposing to repeal regulation governing animal care practices and claiming agency lacked authority to issue regulation).

The FCC's repeal of net neutrality also claimed the earlier policy exceeded the agency's power under the governing statute. Restoring Internet Freedom, 82 Fed. Reg. 25,568, 25,573 (proposed June 2, 2017) (to be codified at 47 C.F.R. pts. 8, 20) (concluding that there is "nothing in the [Telecommunications] Act that would extend [the FCC's] jurisdiction" such that it could exercise utility-style regulation to Internet as it did in 2015 rule). The FCC revealed its likely policy change choice and rationale in a declaratory ruling. Declaratory Ruling, Report and Order, and Order on Restoring Internet Freedom, FCC Rcd. CIRC171204. But the declaratory ruling document does not preclude further comment and FCC adjustment. Id. at 1. The Bureau of Land Management's ("BLM") rescission and suspension of a rule about waste and royalties from oil and gas extraction was similarly based on a claim of illegal overreach of statutory authority, although included a fallback claim of discretionary authority to adjust the policy even if the earlier policy did not violate the statute. See Waste Prevention, Production Subject to Royalties, and Resource Conservation; Delay and Suspension of Certain Requirements, 82 Fed. Reg. 58,050, 58,050 (Dec. 8, 2017) (to be codified at 43 C.F.R. pts. 3160, 3170) (pointing out challenge of prior rule surviving judicial review); Waste Prevention, Production Subject to Royalties, and Resource Conservation; Rescission or Revision of Certain Requirements, 83 Fed. Reg. 7924, 7927 (proposed Feb. 22, 2018) (to be codified at 43 C.F.R. pts. 3160, 3170) (stating that "BLM is not confident that all provisions of the 2016 final rule [the previous rule] would survive judicial review” and highlighting critical comments arguing that "BLM's proposed rule exceeded the BLM's statutory authority”).

104 Compare Extension of the Designation of Haiti for Temporary Protected Status, 82 Fed. Reg. 23,830, 23,831-32 (May 24, 2017) (extending TPS due to lingering earthquake effects but also other risks to safety, such as compounding storm events, agricultural harvest problems, weak public health system, cholera epidemic, lack of safe water, extreme poverty, corruption, and government instability), and Extension of the Designation of El Salvador for Temporary Protected Status, 81 Fed. Reg. 44,645, 44,647 (July 8, 2016) (extending TPS status due to safety risks from initial TPS-triggering earthquake but noting other statutorily specified sources of risks to safety to explain extending TPS status), with Termination of the Designation of Haiti for Temporary Protected Status, 83 Fed. Reg. 2648, 2650 (Jan. 18, 2018) (terminating status because "conditions for Haiti's designation ... relating to the 2010 earthquake ... are no longer met" and limiting analysis to effects of that one event), and Press Release, Kirstjen M. Nielsen, Sec'y of Homeland Sec., Dept. of Homeland Sec., Announcement on Temporary Protected Status for El Salvador (Jan. 8, 2018), available at https://www.dhs.gov/news/2018/01/08/secretary-homeland-security-kirstjen-m-nielsenannouncement-temporary-protected [https://perma.cc/ZS8X-H34Z] (announcing termination of TPS status because "original conditions caused by the 2001 earthquakes no longer exist" and stating that therefore, "under the applicable statute, the current TPS designation must be terminated”). 
its longstanding interpretation of the underlying statute to justify the actions, but it failed to acknowledge that shift or to address additional risks to immigrant safety that it had earlier viewed as legally relevant to determining TPS status. ${ }^{105}$ It now states that it "must" terminate the TPS designation when the conditions for it no longer apply. ${ }^{106}$ Under previous administrations and even in an early Trump Administration action, the agency considered all of the criteria that can justify TPS designations for a nation and ongoing risks to safety, not just the initial triggering event. ${ }^{107}$

In 2017, the FCC, an independent agency, took substantial steps toward abandoning the net neutrality regulation it promulgated in $2015 .{ }^{108}$ This proposal and the later tentative final order engaged more than most of the other Trump Administration agencies with the earlier action's content and rationales and relied heavily on "predictive judgment" about "increase[d] investment." 109 In the proposal and nominally final order, the FCC also stated that the earlier action was founded on unsound "statutory construction" and claimed the new action is based on a "better reading of the statute." 110 This order, in contrast to other actions of Trump Administration executive agencies, devoted substantial attention to the underlying regulatory history, identified relevant case law about the contours of agency authority, and devoted pages to satisfying the cases setting forth both the FCC's power and the constraints of consistency doctrine. ${ }^{111}$ While the substantive policy reversal is major and its ultimate fate uncertain, its approach to the law regarding policy change is much more consistent with the norm established over multiple administrations.

\section{Environmental Deregulating with Inattention to Science and Past Reasoning}

The Trump Administration's efforts to reverse several high conflict environmental actions by the Obama Administration further reveal aggressive

105 See Termination of the Designation of Haiti for Temporary Protected Status, 83 Fed. Reg. at 2650; Press Release, Dep’t of Homeland Sec., supra note 104.

106 See Termination of the Designation of Haiti for Temporary Protected Status, 83 Fed. Reg. at 2649-50 ("If the Secretary determines that the foreign state no longer meets the conditions for TPS designation, the Secretary must terminate the designation . . ..”).

107 See Extension of the Designation of Haiti for Temporary Protected Status, 82 Fed. Reg. at 23,832 (extending TPS due to lingering earthquake effects but also other risks, including "Haiti's weak sanitation infrastructure”).

108 See Restoring Internet Freedom, 82 Fed. Reg. 25,568, 25,573 (proposed June 2, 2017) (to be codified at 47 C.F.R. pts. 8, 20).

${ }^{109}$ Id.; see also Declaratory Ruling, Report and Order, and Order on Restoring Internet Freedom, FCC Rcd. CIRC1712-04, ๆף 155-200 (reviewing both administrative law constraints and communications law provisions to justify policy change).

110 Restoring Internet Freedom, 82 Fed. Reg. at 25,575.

111 See id. at 25,570-72 (tracing history and rationales behind past policies and new policy); id. at 25,580-82 (reviewing consistency doctrine case law and explaining basis for its policy change). 
views about broad presidential and agency power to change policy. These actions simultaneously use several of the change strategies just discussed, but most are especially notable in their minimal engagement with underlying science, past findings, and past agency reasoning. Here, they are reviewed for the power claims they manifest. ${ }^{112}$

For example, in 2015 during the Obama Administration, the EPA and the Army Corps of Engineers (“Corps") finalized the Clean Water Rule, which sets forth definitions and tests for determining if a particular "water" is subject to federal jurisdiction as a "water[] of the United States." 113 This status is of huge economic and environmental significance: it determines if industrial discharge permits are required for pollution (under Section 402 of the Clean Water Act) and if dredging and filling of such waters is subject to a strong prohibitory presumption (under Section 404 of the Clean Water Act). ${ }^{114}$ As part of generating this 2015 rule, the EPA and the Corps simultaneously sought comment on and finalized a massive document - the Connectivity Report-that summarized all peer-reviewed science regarding the functions of various sorts of waters. ${ }^{115}$ The Clean Water Rule itself followed the Supreme Court's creation of an increasingly unsettled body of law due to three related decisions, one of which resulted in splintered opinions and questions about what constituted the majority view. ${ }^{116}$ The rule was finalized, but it engendered fierce attacks, including an expansive "Ditch the Rule" public relations campaign, and was subsequently stayed by a federal appeals court late in the Obama

112 Analysis of their legal adequacy is provided later in this Article to apply and illuminate this body of doctrine and the contingencies they frame. See infra Part III.

113 Clean Water Rule: Definition of "Waters of the United States," 80 Fed. Reg. 37,054, 37,054 (June 29, 2015).

114 See 33 U.S.C. §§ 1342, 1344 (2012).

115 U.S. Envtl. Prot. Agency, Connectivity of Streams \& Wetlands to DOWNSTREAM WATERS: A REVIEW \& SYNTHESIS OF THE SCIENTIFIC EVIDENCE ES-1 (2015).

116 See Rapanos v. United States, 547 U.S. 715, 732 (2006) (stating, in plurality opinion announcing the Court's judgment, that definition of “ "waters of the United States' includes only relatively permanent, standing or flowing bodies of water” but with concurring opinion by Justice Kennedy and opinion of four dissenters finding broader federal authority and explicitly sharing common views on most rationales and waters that would be protected); Solid Waste Agency of N. Cook Cty. v. U.S. Army Corps of Eng’rs, 531 U.S. 159, 171-72 (2001) (rejecting claim of federal jurisdiction under Clean Water Act (“CWA”) over wholly intrastate, isolated waters such as ponds, gravel pits, and seasonal waters due to their use as migratory bird habitats); United States v. Riverside Bayview Homes, Inc., 474 U.S. 121, 13435 (1985) (upholding broad definition of navigable waters with focus on unavoidable judgment calls in resolving border of land and water in complex hydrological system and due to Act's integrity goals). 
Administration. ${ }^{117}$ In early 2018, the Supreme Court entered the fray, ruling that challenges to this rule had to be filed in district court, not a court of appeals. ${ }^{118}$

The Trump Administration targeted the Clean Water Rule shortly after the President's inauguration. President Trump specifically referenced the rule in an Executive Order, asking the agencies to "review" the rule to "rescind[]" or "revis[e]" it "as appropriate and consistent with law."119 But the President's Order went further than just to tilt the agencies in a deregulatory direction. He asked the agencies to "consider interpreting the" underlying statutory language "in a manner consistent with the opinion of Justice Antonin Scalia" in Rapanos v. United States. ${ }^{120}$

It is the next steps that reveal how consistency doctrine can be embracedeven if distorted-by a President and agencies seeking a major deregulatory shift. In March 2017, the EPA—under the leadership of President Trump's initial appointee as Administrator, Scott Pruitt—and the Corps published a Notice of Intent to reconsider the Clean Water Rule, referencing President Trump's “directive," and also stating that they would consider adopting Justice Scalia's opinion rationales. ${ }^{121}$ The agencies cited FCC v. Fox Television Stations, Inc. ${ }^{122}$ ("Fox") and Motor Vehicles Manufacturers Association v. State Farm Mutual Automobile Insurance Co. ${ }^{123}$ as confirming the agency's power to reconsider a past "decision," then went on to embrace the untethered view of

117 Murray Energy Corp. v. U.S. Dep’t of Def., 817 F.3d 261, 274 (6th Cir. 2016) (denying defendants' motion to dismiss on procedural grounds by determining challenges to rule are subject to direct circuit court review), rev'd sub nom. Nat'l Ass'n of Mfrs. v. Dep't of Def., 138 S. Ct. 617 (2018). There have been public relations efforts to influence this and other regulatory actions. See, e.g., Rachel Augustine Potter, More Than Spam? Lobbying the EPA Through Public Comment Campaigns, Brookings (Nov. 29, 2017), https://www.broo kings.edu/research/more-than-spam-lobbying-the-epa-through-public-comment-campaigns/ [https://perma.cc/8KE2-FELE] (discussing interest groups eliciting massive numbers of comments and attributing "Ditch the Rule" campaign to American Farm Bureau Federation).

${ }^{118}$ Nat'l Ass'n of Mfrs., 138 S. Ct. at 624.

119 Exec. Order No. 13,778, 82 Fed. Reg. 12,497 (Mar. 3, 2017). The Order is titled "Restoring the Rule of Law, Federalism, and Economic Growth by Reviewing the 'Waters of the United States’ Rule.” Id. at 12,497.

120547 U.S. 715 (2006) (plurality opinion); Exec. Order No. 13,778, 82 Fed. Reg. at 12,497. Because Justice Scalia's opinion represented a plurality of the Court, and two different majorities read the statute and regulatory power differently, it is questionable if the agency could adopt Justice Scalia's approach. Moreover, unlike the agencies that issued the Clean Water Rule, Justice Scalia's opinion was not grounded in science, hydrology, or the agencies' expertise, but instead derived from his parsing of statutory and dictionary language. See Rapanos, 547 U.S. at 731-32.

121 Intention to Review and Rescind or Revise the Clean Water Rule, 82 Fed. Reg. 12,532, 12,532 (Mar. 6, 2017).

122556 U.S. 502 (2009).

123463 U.S. 29 (1983). 
agency policy change power. ${ }^{124}$ This is apparent in both what the agencies said and what they omitted.

Quoting portions of these cases, the agencies stated that "such a revised decision need not be based upon a change of facts or circumstances," but can be based "on a revaluation of which policy would be better in light of the facts" and a "change in administration brought about by the people casting their votes."125 But the notice grappled with no past science, did not mention the Connectivity Report, did not proffer any analysis of the environmental impacts of dropping the Clean Water Rule, and did not include any legal analysis of the contours of what the agency thought in the past and at the time of the new proposal as to what it is permissible under the law. In proposing to adopt Justice Scalia's view of what waters are protected, the agencies were engaging in another variant of statutory abnegation, substantially shrinking their claimed regulatory power from that asserted in 2015. ${ }^{126}$

And in a related solicitation of public comments about pursuing this policy change in two steps, with the first characterized as restoring the law to where it stood before the 2015 Clean Water Rule, the agencies even sought to limit public comments such that they would not address underlying science or policy impacts or the overall repercussions of the regulatory shift. ${ }^{127}$ It, too, ignored science and environmental impacts. Yet a third notice and then finalized rule added an "applicability date" delaying any implementation of the Clean Water Rule for two years. ${ }^{128}$ That action also provided no engagement with science, facts, or

${ }^{124}$ Intention to Review and Rescind or Revise the Clean Water Rule, 82 Fed. Reg. at 12,532. These are two of the three recent major cases regarding policy consistency doctrine. Fox, 556 U.S. at 515 (finding FCC's policy on censuring language is acceptable on grounds that "it suffices that the new policy is permissible under the statute"); State Farm, 463 U.S. at 42 (holding that "agency changing its course by rescinding a rule is obligated to supply a reasoned analysis for the change beyond that which may be required when an agency does not act in the first instance”). See Section II.C for further analysis of these cases.

125 Intention to Review and Rescind or Revise the Clean Water Rule, 82 Fed. Reg. at 12,532 (quoting Nat'l Ass'n of Homebuilders v. EPA, 682 F.3d 1032, 1038, 1043 (D.C. Cir. 2012)).

126 Justice Scalia’s opinion did not garner a Court majority. See supra notes 115-120 and accompanying text. Moreover, in counting votes and positions, this quite clearly was a minority view on the extent of government power to protect waters. If adopted as the final view of agency power, it would also disclaim a substantial portion of federal authority earlier stated under the Clean Water Rule, federal briefing, and in light of relevant science and the Connectivity Report.

127 Definition of "Waters of the United States"-Recodification of Pre-Existing Rules, 82 Fed. Reg. 34,899, 34,903 (proposed July 27, 2017) (stating that agencies were not seeking comment on pre-2015 rules or "scope of the definition of 'waters of the United States"” until second step of two-step process).

128 See Definition of "Waters of the United States"-Addition of an Applicability Date to 2015 Clean Water Rule, 82 Fed. Reg. 55,542, 55,544-45 (proposed Nov. 22, 2017) (proposing applicability date and reiterating that agencies were not soliciting comment on scope of definition of "waters of the United States" "[b]ecause the agencies propose to simply add the 
past reasoning, let alone law regarding agency policy change or judicial rejections of similar stay or postponement strategies. ${ }^{129}$

Then, in June of 2018, EPA and the Corps published yet another watersrelated notice, this time a new "Supplemental Notice of Proposed Rulemaking" that provided additional questions and proposals linked back to the July 2017 repeal proposal, which remained pending a year after its proposal. ${ }^{130}$ This Supplemental Notice, for the first time in deregulatory actions related to the Clean Waters Rule, delved in more than a cursory manner into issues of science and also discussed the Connectivity Report. ${ }^{131}$ Similar language and advocacy relying on language snippets from Fox and State Farm appeared in several other EPA policy change notices. ${ }^{132}$

A similar combination of citation, justification, limiting of comment, splintering of regulatory actions, and lack of engagement with materials previously viewed as central was evident in the late 2017 and 2018 EPA proposals to repeal the Obama Administration's Clean Power Plan (“CPP”). The CPP regulation was finalized in 2015. It was designed to limit greenhouse gas ("GHG") emissions from power plants due to their climate impacts. ${ }^{133}$ The CPP was issued following three Supreme Court decisions that affirmed EPA authority to regulate GHGs, one of which specifically referenced Section 111(d) of the Clean Air Act as providing EPA authority to regulate existing power plant

applicability date and ensure continuance of the legal status quo and because it is a temporary, interim measure pending substantive rulemaking"); see also Definition of "Waters of the United States"-Addition of an Applicability Date to 2015 Clean Water Rule, 83 Fed. Reg. 5200, 5202-03 (Feb. 6, 2018) (emphasizing lack of associated costs and benefits due to claimed maintenance of legal status quo of Clean Water Rule finalized but not yet in effect due to judicial stays). For a discussion of the legal adequacy of this rule and its judicial rejection, see infra note 372 and accompanying text.

129 Definition of "Waters of the United States"-Addition of an Applicability Date to 2015 Clean Water Rule, 83 Fed. Reg. at 5205 (addressing public comments on delay and avoiding any discussion of substance of underlying rule by claiming that agencies satisfied their duty under APA by explaining their rationale as "provid[ing] for regulatory certainty and ... maintain[ing] the legal status quo" and seeking public comment).

130 Definition of "Waters of the United States-Recodification of Preexisting Rule, Supplemental Notice of Proposed Rulemaking, 83 Fed. Reg. 32,227, 32,231-50 (July 12, 2018).

${ }^{131} I d$. at 32,228-29, 32,240-42 (focusing on science issues, "significant nexus” analysis, and implications of Connectivity Report).

132 See infra note 368-369 and accompanying text (reporting on Federal Register notices relying on similar foundation).

133 Carbon Pollution Emission Guidelines for Existing Stationary Sources: Electric Utility Generating Units, 80 Fed. Reg. 64,662, 64,662 (Oct. 23, 2015) (“[T]his action ... establish[es] final emission guidelines for states to follow in developing plans to reduce greenhouse gas (GHG) emissions from existing fossil fuel-fired electric generating units ....). 
emissions. ${ }^{134}$ Furthermore, the EPA had, in a separate finalized and judicially upheld rulemaking, extensively documented climate science and associated health and environmental "endangerments" resulting from GHG emissions and climate change. ${ }^{135}$ That finding, plus the Court's precedents, had been viewed by EPA as triggering a mandatory duty to regulate due to the "shall" language in Section 111(d). ${ }^{136}$

In 2017, however, the EPA proposed to repeal the CPP. Its notice proffered a different read of the statute that focused on coal plant hardships and claimed consistency with an earlier "inside the fenceline" EPA approach to sources regulated under Section 111(d). ${ }^{137}$ The EPA proposed a complete repeal of the CPP, but without committing to any replacement rule. ${ }^{138}$ It too cited a few consistency doctrine precedents and, as with the Clean Water Rule repeal proposals, sought to limit public comment. ${ }^{139}$ It offered a new power-limiting interpretation of the statute similar to other agencies' statutory abnegation

134 See William W. Buzbee, Federalism Hedging, Entrenchment, and the Climate Challenge, 2017 WIS. L. REV. 1037, 1071-81 (reviewing cases and regulatory actions leading to creation of CPP).

${ }^{135}$ Id. at 1075 (reviewing risks of climate change and "the 'car deal' that was issued with industry, state, and federal agreement to future auto emissions reductions to comply with transportation and environmental laws”).

136 Carbon Pollution Emission Guidelines for Existing Stationary Sources, 80 Fed. Reg. at 64,707-25 (summarizing legal history and basis for design of CPP). In the CPP, the EPA explained its approach as consistent with past rulemakings that required pollution control in light of each industries' particular attributes. It emphasized that power plants were already adjusting pollution levels through use of the interconnected and integrated energy grid. Id. at 64,727-33 (reviewing “measures available because of the integrated electricity system”).

137 See Repeal of Carbon Pollution Emission Guidelines for Existing Stationary Sources: Electric Utility Generating Units, 82 Fed. Reg. 48,035, 48,038 (proposed Oct. 16, 2017) (explaining that EPA proposal to repeal CPP is based on its determination that "performance standards that the CPP established for existing sources" were based upon three inputs, two of which “exceed the EPA's authority under CAA section 111"). The CPP rejected an "inside the fenceline" approach, looking instead at pollution and energy use reductions achieved through trading and adjustments linked to the interconnected electrical grid. Carbon Pollution Emission Guidelines for Existing Stationary Sources, 80 Fed. Reg. at 64723-27, 64758-60, 64768-69. News releases accompanying the repeal proposal explicitly characterized the repeal as abandoning reliance on actions “outside the fence line.” Press Release, Envtl. Prot. Agency, U.S. EPA Takes Another Step to Advance President Trump’s America First Strategy, Proposes Repeal of “Clean Power Plan" (Oct. 10, 2017), available at https://www.epa.gov/newsreleases/epa-takes-another-step-advance-president-trumpsamerica-first-strategy-proposes-repeal [https://perma.cc/ZLM4-LWTM] (stating EPA would return to its "traditional[] . . . inside the fence line" approach).

138 See Repeal of Carbon Pollution Emission Guidelines for Existing Stationary Sources: Electric Utility Generating Units, 82 Fed. Reg. at 48,036.

139 E.g., id. ("EPA is not soliciting comments on such information with this proposal"); see also id. at 48,039 (citing change power cases). 
rationales referenced earlier. ${ }^{140}$ In the repeal proposal, the EPA did not cite other relevant statutory language, cases, and past rulemakings the EPA analyzed in 2015; ignored the EPA's detailed 2014, 2015, and 2017 studies of the electricity sector; ignored state regulatory trends and accomplishments; and nowhere engaged with the EPA's own earlier pro-CPP reasoning. ${ }^{141}$ The EPA did not compare or quantify environmental and health costs flowing from the repeal proposal. While an accompanying Regulatory Impact Analysis contained some relevant numbers and comparisons, the agency there also shifted its analytical framework. ${ }^{142}$ In 2017, the EPA also sidestepped discussion of predicted increases in particulate matter pollution accompanying GHG emissions and thousands of additional predicted deaths, though it had previously viewed such impacts as legally relevant to the CPP due to statutory language requiring agency consideration of the impacts on public health. ${ }^{143}$

Then, in August 2018, the EPA proposed a substantially weakened replacement rule for the CPP, labeling the new proposal the Affordable Clean Energy ("ACE") Rule. ${ }^{144}$ This proposal and accompanying documents again claimed that the CPP exceeded the EPA's statutory authority. ${ }^{145}$ In summary

${ }^{140}$ Id. at 48,035-39.
141 The proposed repeal ignored a 2017 action finding post-2015 to 2017 acceleration of clean energy trends and at decreased costs than predicted in 2015. See U.S. EnVTL. Prot. Agency, Basis for Denial of Petitions to Reconsider and Petitions to Stay the CAA

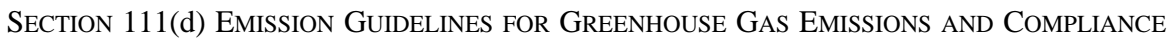
Times FOR ELECTRIC UTILITY GENERATING UNITS 22-30 (2017) (explaining how, in wake of $\mathrm{CPP}$, there was growing trend toward low- and zero-emitting energy).

142 See U.S. Envtl. Prot. Agency, Regulatory Impact Analysis for the Review of THE Clean Power Plan: Proposal 27 (2017) (“This [Regulatory Impact Analysis (“RIA”)] addresses the avoided regulatory compliance costs, forgone emission reduction benefits of the final emission guidelines that are the focus of this action. Additionally, this RIA includes information about potential impacts of the proposed rule on electricity markets, employment, and markets outside the electricity sector. The RIA also presents a discussion of uncertainties and limitations of the analysis.”).

143 The CPP discussed such impacts on health. Carbon Pollution Emission Guidelines for Existing Stationary Sources: Electric Utility Generating Units, 80 Fed. Reg. 64,662, 64,68283 (Oct. 23, 2015) (discussing how "climate change is expected to increase ozone pollution over broad areas of the U.S. ... with impacts on other areas of public health, such as the potential for increased deaths, injuries, infectious and waterborne diseases, and stress-related disorders"). The repeal proposal, however, does not discuss them despite CAA Section 111(a)'s mandate that the agency consider "health . . impact[s]." 42 U.S.C. § 7411(a)(1) (2012).

144 Emission Guidelines for Greenhouse Gas Emissions from Existing Electric Utility Generating Units; Revisions to Emissions Guidelines Implementing Regulations; Revisions to New Source Review Program, 83 Fed. Reg. 44,716 (proposed Aug. 31, 2018).

145 Id. at 44,748 (referring to CPP's "legal flaws”); id. at 44,752-53 (stating that CPP "generation shifting" strategy violated statute that EPA in new proposal views as "unambiguously intended to be source specific" (citation omitted)). In other discussion, it characterizes its new focus on "unit-specific" or "within-the-fenceline" improvements as 
form, EPA alluded to electricity sector trends and resulting lowered emissions, but did not cite or discuss in detail the EPA's own January 2017 petitions denial that discussed acceleration of clean energy trends and also lower than expected associated costs. ${ }^{146}$ The EPA seemed to assume that the CPP created no reliance interests or effects-none are discussed. Apples-to-apples comparisons of the CPP versus the ACE proposal and their benefits and costs, especially GHG reductions, were partly avoided because the EPA in the ACE proposal declined to set an emissions cap for the sector as it had in the CPP. Other comparisons of costs and benefits were analyzed under a different, solely domestic focus, but with changed and largely unexplained estimates of costs and lives lost under the CPP, earlier related proposals, and under the ACE proposal itself. ${ }^{147}$ Unlike in several of the other proposals discussed, the EPA did not in this proposal seek to limit the public's comment or overall arguments about the new proposal's comparative merits.

The Clean Water Rule, the CPP rollback, the replacement proposals, and the final waters "applicability date" rule as described here are only the beginning of lengthy legal battles. Nonetheless, they reveal broad change power claims. The initial wave of actions engaged minimally with previous agency reasoning justifying the preceding actions, limited comments, did not quantify the impacts of their actions, provided scant information on environmental effects, and divided their regulatory steps. They mentioned some relevant case law, but only to emphasize presidential change power. By the summer of 2018, EPA actions (under the leadership of a new administrator, Andrew Wheeler), provided greater justifications and more attention to the usual practices of agencies proposing a policy change. ${ }^{148}$ Most neglect the more recent Encino Motorcars case that spoke in a clear, singular majority opinion and required agencies proposing change to do far more than just point to votes or a view of "better" policy, but also provide "good reasons," 149 a "rational connection between the facts found and the choice made," 150 and leave no "[u]nexplained

within EPA’s power or reasonable and past CPP approach “unreasonable.” Id. at 44,753-54, 47,775.

146 See Basis for Denial of Petitions to Reconsider and Petitions to Stay the CAA SECTION 111(d) Emission Guidelines for Greenhouse Gas Emissions and Compliance Times FOR ElECtric Utility GENERATING Units, supra note 141.

147 Emission Guidelines for Greenhouse Gas Emissions from Existing Electric Utility Generating Units; Revisions to Emissions Guidelines Implementing Regulations; Revisions to New Source Review Program, 83 Fed. Reg. at 44,783-96 (discussing impacts); see also U.S. Envtl. Prot. Agency, Regulatory Impact Analysis for the Proposed Emission GUIDELINES FOR GREENHOUSE GAS EMISSIONS FROM EXISTING ELECTRIC UTILITY GENERATING Units; REVISIONS TO EMISSIONS GUIDELINES IMPLEMENTING REgULATIONS; REVISIONS TO New Source Review Program (2018).

148 For these more fleshed out change proposals, see supra notes 130, 144.

149 Encino Motorcars LLC v. Navarro, 136 S. Ct. 2117, 2125-26 (2016) (quoting FCC v. Fox Television Stations, Inc., 556 U.S. 502, 515 (2009)).

${ }^{150} I d$. 
inconsistency." 151 And by fragmenting the undoing of rules and often seeking to limit comments, most of these actions avoided the fundamental regulatory rescission question: should the agencies be abandoning a past finalized regulation and, if so, why and at what costs?

In a significantly different procedural setting that also involves the environment, President Trump ordered the Corps to reverse its previous commitment to undertake additional environmental review prior to deciding on an easement permit needed for the conflict-laden Dakota Access Pipeline. ${ }^{152}$ His memorandum directed the Corps to "approve in an expedited manner" the project. ${ }^{153}$ The memorandum contained language retaining some role for law and facts - " to the extent permitted by law and as warranted"-but clearly stated the outcome sought. ${ }^{154}$ A couple of weeks later, with a reference to President Trump's "direction," the Corps announced it would grant the easement, rely on earlier analyses, reverse itself, and not undertake any of the additional review it had earlier said was needed. ${ }^{155}$ Here, the President was directing an agency outcome in an adjudicatory setting - albeit an informal adjudication-where private stakeholders were in conflict over a wealth-generating, but also riskcreating, project. As explained below, this sort of explicit presidential direction in an adjudicatory setting is problematic and likely unprecedented. ${ }^{156}$ Legal skirmishing over this permit and pipeline continued, but one court ruling, in a mixed opinion, faulted the agency for bypassing analysis required by the National Environmental Policy Act (“NEPA”). ${ }^{157}$

${ }^{151}$ Id. (quoting Nat'l Cable \& Telecomms. Ass’n v. Brand X Internet Servs., 545 U.S. 967, 981 (2005)). For analysis of the key consistency precedents, see infra Section II.C.

152 Construction of the Dakota Access Pipeline, Memorandum for the Secretary of the Army, 82 Fed. Reg. 11,129 (Jan. 24, 2017).

153 Id.

${ }^{154} I d$.

155 Letter from Paul D. Cramer, Deputy Assistant Sec'y of the Army, to Representative Raul Grijalva, Ranking Member, U.S. House of Representatives Comm. on Nat. Res. (Feb. 7, 2017) (providing notice to Congress of Army's intent to grant Dakota Access easement).

156 Despite broad agreement that presidents cannot claim directive authority over —or have ex parte contacts in connection with-formal adjudicatory procedures, informal adjudicatory actions are generally viewed as providing more latitude for presidential directions and political nudges, but with risks remaining due to bias and prejudgment in settings of competing interests and fact and context-specific judgments. For further analysis see infra Section IV.D. See also Percival, supra note 3, at 2487-532 (tracing assertions of directive authority and regulatory review by presidential administrations from Nixon to Obama); Strauss, supra note 3, at 967-68 (questioning whether President's role in, and potential control over, rulemaking should be cause for concern).

157 Standing Rock Sioux Tribe v. U.S. Army Corps of Eng'rs, 255 F. Supp. 3d 101, 13643 (D.D.C. 2017) (finding several elements of Corps' analysis of its environmental risks arbitrary and capricious, but rejecting arguments of illegal failure to follow policy change precedents' requirements). 
This Article now turns to an analysis of the most relevant governing precedents and bodies of law making up consistency doctrine. It returns later to assess the legality and accuracy of these strong claims of largely unfettered agency change power.

\section{Agencies, Presidents, AND Policy Change Conditions}

It is indisputable that the baseline norm is that agencies can change their policies over time as they gain experience. ${ }^{158}$ Nonetheless, the power to adjust policy is separate from the conditions and requirements an agency must satisfy to justify such changes. ${ }^{159}$ This Article suggests that the conception of a tethered president, and tethered agencies as well, is an important frame to emphasize that while there is ordinarily room for some policy movement, that movement is always subject to constraints. And under an array of cases and linked doctrine, the obligation of agencies to engage with regulatory contingencies is at the heart of tethering constraints and analysis of the legality of agency policy shifts.

\section{A. Enabling Act Constraints}

The first and most important constraint is the statutory language that authorizes the disputed regulatory act. ${ }^{160}$ The most fundamental obligation of a President and executive branch agencies is to "take Care" that the thousands of laws they must implement and enforce "be faithfully executed." 161 Such faithful legal execution includes several necessary elements. ${ }^{162}$ First, statutes reflect a congressional choice of delegate. Sometimes they confer authority and obligations on a President, but, more often, such enabling acts confer authority on a particular department or regulator. ${ }^{163}$ The specificity or breadth of that delegation is itself an implicit constraint on the President. ${ }^{164}$

158 See supra Section I.A (discussing expectation and reasoning behind agencies creating and changing policy).

159 See infra Section II.C (reviewing major decisions regarding consistency doctrine and agency justification for change); Section II.G (discussing pitfalls of poorly explained policy).

160 See Massachusetts v. EPA, 549 U.S. 497, 532-33 (2007) (emphasizing centrality of statutory criteria in guiding agency action); La. Pub. Serv. Comm’n v. FCC, 476 U.S. 355, 374 (1986) (stating "an agency literally has no power to act . . . unless and until Congress confers power upon it”).

161 U.S. CONST. art. II, § 3.

162 Metzger, supra note 33, at 1332-42; Metzger, supra note 39, at 1875-78 (discussing President's role in supervision of agencies and parsing Take Care Clause).

163 See Stack, supra note 3, at 267 (documenting different congressional statutory choices to delegate power to President or to agencies and arguing that President only has statutory authority to act under statutes that directly grant such authority to him).

164 See Percival, supra note 3, at 2495 ("Traditional principles of statutory interpretation dictate that if Congress deems it necessary in some circumstances to specify when the President may exercise authority to override an agency decision, such authority should not be inferred when Congress has not so specified.”); Stack, supra note 3, at 267, 284 (arguing for 
Second, statutes will state their purposes and in operative provisions the particular tasks, means, and criteria shaping how the agency is to achieve statutory goals. ${ }^{165}$ And barring an enabling act offering some additional or contrary process, the Administrative Procedure Act's ("APA") notice-andcomment procedures must precede an agency promulgation of a rule that ends up being explained in the Federal Register and finally codified in the Code of Federal Regulations. ${ }^{166}$ Importantly, as reviewed below, these notice-andcomment obligations exist for brand new regulations, revisions to them, or deregulatory rulemakings. Hence, laws provide goals, criteria, and procedural choices. Any agency making new policy, whether a new initiative or a change to an existing one, will need to abide by this combination of substantive and procedural constraints. ${ }^{167}$

One caveat is necessary here. Barring statutory or regulatory language mandating action, a line of cases dating back to the 1970s gives the President and agencies presumptive control over when and how they will implement and enforce the law, especially where that choice involves resource allocation

enforcement of congressional choices despite President's role as head of executive branch, due to varying congressional choices regarding delegations to agencies or presidents); $c f$. Zarda v. Altitude Express, Inc., 883 F.3d 100, 115 (2d Cir. 2018) (en banc) (stating that broad statutory language provides room for statutory coverage beyond "principal evil to cover reasonably comparable evils" and is not limited by "the principal concerns of our legislators" (quoting Oncale v. Sundowner Offshore Servs., Inc., 523 U.S. 75, 79 (1998))). Both linguistic breadth and specificity can impose constraints since an agency might claim expansive or limited powers. In either setting, the delegation language would shape the reasonableness of those power claims. For a defense of delegations of broad authority to agencies due to their expertise, transparent process, and rigorous judicial review and the "public trust" thereby engendered, see Edward H. Stiglitz, Delegating for Trust, 166 U. PA. L. REV. 633, 637-40, 672 (2018).

165 Professor Metzger argues that congressional structural, procedural, and agency role allocations should be given more weight by reviewing courts. Metzger, supra note 33, at 1366-69. The Supreme Court in Massachusetts v. EPA did focus on such factors and rejected agency reliance on other considerations. See Massachusetts v. EPA, 549 U.S. 497, 526-28 (2007); supra note 8 (citing scholarship analyzing Massachusetts v. EPA and its statutory and expertise-based focus); see also Gonzales v. Oregon, 546 U.S. 243, 244 (2006) (rejecting authority of interpretive rule issued by Attorney General in light of specificity of allocated and preserved regulatory roles for several regulators, federalism concerns and divisions reflected in statute, and also rejecting claim of deference due to lack of process preceding rule's issuance).

166 See Metzger, supra note 33, at 1348-52 (discussing role of APA and how it sometimes constrains courts' ability to develop administrative law doctrine in common law-like manner).

167 See Bluewater Network v. Salazar, 721 F. Supp. 2d 7, 21-23, 30, 40 (D.D.C. 2010) (analyzing statutory goals guiding National Park Service agency power and discretion to revise policies, but stating "that discretion is 'bounded by the terms of the Organic Act itself'" and rejecting as inadequate agency's attention to facts behind old and new actions (citations omitted)). 
choices delegated by Congress to the agency. ${ }^{168}$ A degree of deregulatory impact can be achieved simply through non-enforcement, although citizen suit provisions and other private causes of action, plus enforcement by state and local governments, often ensure the law does not become a dead letter. ${ }^{169}$ Weak implementation and enforcement of laws and regulations that may remain unchanged is often difficult or even impossible to challenge in court. ${ }^{170}$ It might, however, be different if an agency overtly adopted a policy of legal "abdication," as noted in Heckler v. Chaney. ${ }^{171}$ Such agency and presidential choices about priorities and their regulatory agenda are likely at the apex of room for discretionary choice. ${ }^{172}$ Nonetheless, as strongly stated in Massachusetts v. EPA, when an agency does act, it must root its choices in what the underlying statute requires. ${ }^{173}$

\section{B. Policy Change Process, Deliberative Opportunities, and Integrity}

When agencies seek to change policy, they will ordinarily be subject to stakeholder input either because it is required or to strengthen the agency's position when reviewed in court. ${ }^{174}$ Agencies that short-circuit such processes and deliberative opportunities, as seen in major policy change actions just reviewed, make their actions vulnerable to judicial invalidation.

Agencies can change policies under an unchanged enabling act due either to intentional congressional conferral of power that mandates periodic reassessments, or statutory language that confers substantial discretion to agencies, or often by virtue of implicit delegations of authority. Long before

168 For an analysis of agencies' latitude to choose procedurally how to make policy, see M. Elizabeth Magill, Agency Choice of Policymaking Form, 71 U. CHI. L. REv. 1383 (2004). For an analysis of general unreviewability of agency choices not to enforce or how to allocate resources, see Ronald Levin, Understanding Unreviewability in Administrative Law, 74 Minn. L. REV. 689, 702-34 (1990).

169 See generally Eric Biber, Two Sides of the Same Coin: Judicial Review of Administrative Agency Action and Inaction, 26 VA. ENVTL. L.J. 461 (2008) (arguing that there is no real difference between decision to regulate or not to regulate under APA); Daniel T. Deacon, Note, Deregulation Through Nonenforcement, 85 N.Y.U. L. REV. 795, 797 (2010) (discussing issue and citing to Biber and other scholars analyzing inaction law).

170 See, e.g., Norton v. S. Utah Wilderness All., 542 U.S. 55, 55 (2004) (unanimously holding that APA only allows courts to examine government agencies' failures to act where action is required and discrete); Heckler v. Chaney, 470 U.S. 821, 821 (1985) (concluding that nonenforcement choices by agencies are presumptively unreviewable in federal courts); Levin, supra note 168, at 704-05 (discussing Supreme Court's decision in Citizens to Preserve Overton Park v. Volpe and its treatment of unreviewability under APA).

171470 U.S. 821, 833 (1985).

172 See Watts, supra note 17, at 2 (arguing for legitimacy of political involvement and considerations in setting priorities and allocating resources if not subject to countervailing or constraining congressional framework).

173 See supra note 8 and accompanying text.

174 See Bressman, supra note 69, at 776; Magill, supra note 168, at 1390. 
modern deference framework cases, courts deferred to agency interpretations of their enabling acts due to their expertise and congressional choice of the regulators, even without explicit delegation of agency power to act through rulemaking. ${ }^{175}$ Today, which deference framework shapes judicial review generally hinges on the procedural mode through which the agency acts. ${ }^{176}$

An agency's procedural choices about how to act and make policy, unless constrained by statute or an agency's own regulations or policy developed over time, have long been viewed as within the agency's discretion. ${ }^{177}$ Agencies can make policy through regulations, usually using a notice-and-comment process, but also can make policy on a case-by-case basis through adjudications or also through guidance and policy documents not vetted in a notice-and-comment process. ${ }^{178}$ The authoritativeness of the derived policy, its durability, and deference frames will vary depending on the policymaking mode. ${ }^{179}$

A meta-rule is critical to understanding consistency doctrine: an agency can only change policy through an equal or more formal procedural mode than initially utilized. ${ }^{180}$ And in the modern era, when formal agency actions are a rarity, this usually means that regulations generated through a notice-andcomment process stand at the top of the authority hierarchy. To state it more simply, to amend a fully effective rule promulgated through a notice-andcomment process requires another rulemaking-it takes a regulation to displace

175 There are two foundational pre-APA cases explaining rationales for judicial deference to agencies, but with analysis that blends review of legal and factual determinations. See Skidmore v. Swift \& Co., 323 U.S. 134, 139, 140 (1944) (explaining why agency views about law and facts deserve "respect," deference, and “in some cases decisive weight” since agency will have “more specialized experience”); NLRB v. Hearst Publ’ns, Inc., 322 U.S. 111, 130 (1944) (stating that "it is not the court's function to substitute its own inferences of fact for the [NLRB's]" because "Congress entrusted” to NLRB such determinations).

176 See infra notes 182-197 (discussing deference frameworks).

177 See Magill, supra note 168, at 1398 (acknowledging "ability of agencies to choose among a range of policymaking forms”).

178 See id. at 1386-97 (describing and evaluating process and effects of different modes of policymaking); see also, e.g., Perez v. Mortg. Bankers Ass’n, 135 S. Ct. 1199, 1206 (2015) (holding that federal agencies need only utilize notice-and-comment procedures when enacting or changing "force of law" legislative rules, not when altering interpretive rules); Vt. Yankee Nuclear Power Corp. v. Nat. Res. Def. Council, Inc., 435 U.S. 519, 520 (1978) (holding that APA imposes maximum procedural requirements that courts can impose on agencies unless more is required by enabling act or agency's own regulations); SEC v. Chenery Corp., 332 U.S. 194, 203 (1947) (stating that “choice made between proceeding by general rule or by individual, ad hoc litigation is one that lies primarily in the informed discretion of the administrative agency").

179 See generally Peter L. Strauss, The Rulemaking Continuum, 41 DuKE L.J. 1463 (1992).

180 Perez v. Mortgage Bankers Association confirms this basic proposition, although it does so in reversing a lower court decision calling for notice-and-comment rulemaking before abandoning a policy announced in a guidance interpretive document. See Perez, 135 S. Ct. at 1206. 
another regulation. ${ }^{181}$ And, as further analyzed below, that basic rule of law proposition involves a requirement that an agency fully engage with the issues, disputes, and past reasoning of the linked earlier agency action.

When an agency is construing substantive provisions of an enabling act, versus choosing procedurally how to act, it will receive deference too. After the Mead and State Farm decisions, agencies hoping to maximize judicial deference generally will act through a notice-and-comment process. ${ }^{182}$ Due to the prevalence of statutory gaps, silences, and ambiguities, most agency regulations involving interpretation of statutory language will trigger deference under Step Two of the Chevron framework. ${ }^{183}$ If the disputed policy and underlying interpretation is generated through some less formal mode, such as in a guidance document, in a brief, or through other modes lacking an advance participatory vetting process, then review will usually be under the Skidmore v. Swift \& Co. ${ }^{184}$ standard. ${ }^{185}$ Skidmore provides for a "sliding scale" review looking at numerous factors, especially the thoroughness of the agency's consideration and its persuasiveness. ${ }^{186}$ As further developed below, the more thorough the process and agency reasoning accompanying notice-and-comment rulemaking, the more the agency will be aided when subsequently faced with judicial "hard look review" and linked "reasoned decisionmaking" obligations that focus on disputed contentions and agency responsiveness. ${ }^{187}$ But the very thoroughness of resulting agency process and explanation erects hurdles for later proponents of policy change.

181 See Am. Mining Cong. v. Mine Safety \& Health Admin., 995 F.2d 1106, 1109 (D.C. Cir. 1993) (stating that "amendment to a legislative rule must itself be legislative" (quoting Nat'l Family Planning \& Reprod. Health Ass’n v. Sullivan, 979 F.2d 227, 235 (D.C. Cir. 1992)) (internal quotation marks omitted)); Envtl. Def. Fund v. Gorsuch, 713 F.2d 802, 815 (D.C. Cir. 1983) (highlighting APA Section 551(5)'s inclusion of “repeal of a rule” as among forms of rulemaking).

182 See Magill, supra note 168, at 1384-85 (describing shift from agencies mostly deciding individual cases to agencies promulgating more legislative rules).

183 Levin, supra note 26, at 1254 (explaining Chevron two-step framework and noting second step’s overlap with “arbitrary and capricious review”).

184323 U.S. 134 (1944).

${ }^{185} \mathrm{Id}$. at 140 . For non-notice-and-comment rules or other forms of agency action, the framework for judicial review is generally stated in Skidmore. Id. Perez affirmed this. See Perez, 135 S. Ct. at 1204 (noting that "interpretative rules do not have the force and effect of law” (quoting Shalala v. Guernsey Mem’l Hosp., 514 U.S. 87, 99 (1995)) (internal quotation marks omitted)). For an exploration of the differences between the logic and analyses required under Chevron and Skidmore, see Peter L. Strauss, "Deference is Too Confusing-Let's Call Them "Chevron Space" and "Skidmore Weight," 112 ColuM. L. REv. 1143, 1153-72 (2012).

186 Skidmore, 323 U.S. at 140 (noting factors for review are "thoroughness evident in [the rule's] consideration, the validity of its reasoning, its consistency with earlier and later pronouncements, and all those factors which give it power to persuade ....”).

187 See infra Section II.E (explaining “reasoned decisionmaking” requirement). 
When it comes to consistency and agency latitude for change, Chevron and Skidmore are in tension in their language. In Chevron, a notice-and-comment rulemaking resulted in a major change in policy that was upheld by the Supreme Court. ${ }^{188}$ The agency shifted from interpreting "stationary source" to create a stack-by-stack trigger for pollution control upgrade obligations to allowing states to utilize a "bubble" strategy. ${ }^{189}$ Under the bubble strategy, polluters could, through internal pollution trading, save money by not triggering heightened pollution control obligations. ${ }^{190}$ The agency explained how the stack-by-stack approach could chill new investments and raise costs, but at little or perhaps no environmental benefit since upgrades might not be made. ${ }^{191}$

Instead of viewing the policy change by the EPA as a problem, the Chevron Court actually saw policy reconsiderations, and especially the EPA shift under review, as laudable. To engage in "informed rulemaking," the Court declared, an agency "must consider varying interpretations and the wisdom of its policy on a continuing basis." 192 And this obligation, and accompanying judicial deference, was viewed as especially necessary "in the context of implementing policy decisions in a technical and complex arena." ${ }^{193}$ But, importantly, the Court also emphasized that, under the statute, the agency unavoidably had to reconcile competing policy goals of economic growth and clean air, and found that rulemaking comments, empirical observations, and economic theory supported the agency's policy shift. ${ }^{194}$

In contrast, the Skidmore case retains "consistency" as one of its sliding scale factors weighing in favor of the agency's policy, and, after Mead, the Skidmore framework applies to pretty much all modes of agency action other than formal action or notice-and-comment rulemaking. ${ }^{195}$ However, despite Chevron's language, judges often still consider consistency when assessing the reasonableness of an agency decision, even in settings that seem to fall into the

188 See Chevron U.S.A., Inc. v. Nat’l Res. Def. Council, Inc., 467 U.S. 837, 842 (1984) (upholding regulation and articulating deference framework now known as Chevron TwoStep).

${ }^{189}$ Id. at 840-42, 851-59, 863 (reviewing derivation of "bubble" strategy and reasons for its adoption).

190 See id. at 863 (noting economic growth as justification for agency’s rule).

191 Id. at 855-63 (emphasizing policy rationales for rule).

192 Id. at 863-64.

193 Id. at 863. For discussion of this Chevron language, see Kozel \& Pojanowski, supra note 7, at 125. This element of Chevron has spawned a massive body of scholarship. See, e.g., John F. MANNing \& MatThew C. StePHENSON, LEgislation AND REgulation 970-92 (3d ed. 2017) (reviewing leading scholarly analyses of Chevron).

194 See Chevron, 467 U.S. at 863-64.

195 Skidmore v. Swift \& Co., 323 U.S. 134, 140 (1944) (noting “consistency” as factor for review). Mead made clear that Skidmore provides the scope of review framework when the underlying law or agency's procedural choices render Chevron deference inapplicable. United States v. Mead Corp., 533 U.S. 218, 234-35 (2001). 
heart of Chevron deference. ${ }^{196}$ One recent study found that consistency was a still a prevalent, if not dominant, factor assessed by reviewing courts. ${ }^{197}$

\section{Inconsistency, Politics, and Facts}

Three major, modern Supreme Court decisions contain extended analyses of consistency doctrine and, in particular, the role that politics versus fact-linked contingencies can play when agencies seek to justify a policy shift. And a fourth, Massachusetts $v$. EPA, also involved a policy change and discussion of permissible grounds for such a shift, although with less of a focus on consistency doctrine. In ways that are either being overlooked or mischaracterized in the recent change power claims reviewed in Part I, these cases do not embrace politics as a sufficient rationale for a policy shift. They do not permit regulatory shifts based on regulatory whim. Instead, they note that politics can motivate a reexamination of policy, that policy shifts are possible, and say that close policy judgment calls go to the agency. But these decisions also emphasize the need for an agency to confront fully its earlier actions, its past explanations, and especially facts or circumstances relevant to the old and possible new policy. Agencies cannot ignore the contingencies-which are made relevant by the applicable statutes - that underlie initial actions proposed for later policy change.

The foundational modern case is the Supreme Court's decision in Motor Vehicle Manufacturers Association v. State Farm. The case is most known for its embrace of "hard look review" and its articulation of the key elements of "reasoned decisionmaking." 198 Nonetheless, in its rejection of a Reagan-era rescission of promulgated car safety standards, the Court set forth the key elements of consistency doctrine. ${ }^{199}$ The Court was confronted with the National

196 See, e.g., Util. Air Regulatory Grp. v. EPA, 134 S. Ct. 2427, 2449 (2014) (rejecting EPA's newly claimed authority due to several factors, among them its novelty under longstanding law); Gonzales v. Oregon, 546 U.S. 243, 255-75 (2006) (declining to uphold Attorney General's interpretive regulation in part due to inconsistency with past authority claims, lack of adequate notice and opportunity for comment, and statute's allocation of particular roles to particular actors); Smiley v. Citibank (S.D.), N.A., 517 U.S. 735, 747 (1996) (upholding bank regulation as reasonable under Chevron framework); Rust v. Sullivan, 500 U.S. 173, 186-87 (1991) (rejecting consistency-based challenge to deference and upholding new interpretation of Federal Housing Administration ("FHA") regulation); INS v. Cardoza-Fonseca, 480 U.S. 421, 423-24 (1987) (rejecting Chevron deference due to change in statutory construction that contradicted clear congressional intent and historically held agency interpretation).

197 See William N. Eskridge, Jr. \& Lauren E. Baer, The Continuum of Deference: Supreme Court Treatment of Agency Statutory Interpretations from Chevron to Hamdan, 96 GEO. L.J. 1083, 1150 (2008) (finding correlation between win-rate and use of consistency as factor, even in cases where Chevron is applied).

198 Id. at 42-52 (embracing and setting forth key elements of "hard look review" and “reasoned decisionmaking”).

199 Id. at 41-44. 
Highway Traffic and Safety Administration's rejection of Standard 208, a regulation that required cars to be equipped with either air bags or automatic seatbelts. ${ }^{200}$ The agency, however, only offered an explanation for one of the regulatory reversals and argued for minimal judicial scrutiny of its deregulatory action. ${ }^{201}$

The Court rejected this argument for minimal scrutiny, emphasizing the need for an agency to confront its old policy and offer explanation for the change. An agency, the Court stated, when "changing its course" is required to "supply a reasoned analysis for the change beyond that which may be required when an agency does not act in the first instance."202 Half of the agency's action was easy to find arbitrary and capricious because the agency "apparently gave no consideration whatever" to keeping one of the safety strategies. ${ }^{203}$ "Not one sentence of its rulemaking statement discusses the airbags-only option," the Court emphasized. 204

The State Farm Court explained why it declined to subject a deregulatory policy change to some less rigorous standard of review. First, the APA made no such distinction. ${ }^{205}$ Second, the enabling act language made no distinction between initial regulatory actions and rescissions of past actions. ${ }^{206}$ Third, the Court explained that the usually minimal review of agency declinations to act was "substantially different" from an agency's "revocation of an extant regulation." 207 Such revocation "constitutes a reversal of an agency's former views as to the proper course." 208 And, quoting an earlier precedent's language, the Court stated that a "settled course of behavior embodies the agency's informed judgment" that the earlier action "will carry out the policies committed to it by Congress." ${ }^{09}$ This creates "at least a presumption that those policies will be carried out best if the settled rule is adhered to.”210

200 Id. at 34.

201 Id. at 41.

202 Id. at 42. The tail clause, stating that more is required than "when an agency does not act in the first instance," is rejecting arguments that a deregulatory act is akin to an agency's choice not to act or regulate, a setting subject either to no judicial review or deferential review. Id.; see supra notes 168-172 and accompanying text (discussing literature and cases on unreviewability).

${ }^{203}$ State Farm, 463 U.S. at 46.

${ }^{204}$ Id. at 48; see also id. at 50 (stating that "agency submitted no reasons at all").

205 See id. at 41.

${ }^{206}$ Id. (noting that National Traffic and Motor Vehicle Safety Act "expressly equates orders 'revoking' and 'establishing' safety standards”).

${ }^{207} \mathrm{Id}$.

${ }^{208} \mathrm{Id}$.

${ }^{209}$ Id. at 41-42 (quoting Atchison, Topeka \& Santa Fe Ry. Co. v. Wichita Bd. of Trade, 412 U.S. 800, 807 (1973)) (internal quotation marks omitted).

${ }^{210} \mathrm{Id}$. For an analysis of statutory interpretation and judicial review standards for "longstanding” agency law interpretations, see Anita Krishnakumar, Longstanding Agency Interpretations, 83 FORDHAM L. REV. 1823 (2015). Professor Krishnakumar calls for more 
Of course, the Court continued, agencies can seek to change policy. ${ }^{211}$ But even with that language, the Court linked the possibility of change not to politics or just examination of statutory language, but to the need for "ample latitude to 'adopt their rules and policies to the demands of changing circumstances." "212 It reiterated the "changing circumstances" language and stated that the presumption is "against changes in current policy that are not justified by the rulemaking record." 213 Hence, the State Farm Court left room for agency policy change, but emphasized how past agency reasoning, the record, and underlying circumstances would need to be engaged and overcome to justify a change.

Chief Justice Rehnquist, in a partial dissent, suggested that a change of administration and policy priorities could be among the grounds for an agency policy shift, although his embrace of politics as a justification for change is actually quite modest. He only stated that they could be a "reasonable basis for an executive agency's reappraisal of the costs and benefits of its programs and regulations."214 This view did not gain majority support.

The Court's Massachusetts v. EPA decision did not focus on doctrine governing consistency and policy change, but it too involved a policy change grounded in both a new statutory interpretation, as well as presidential priorities and discretion. ${ }^{215}$ A petition sought EPA regulation under the Clean Air Act of GHG emissions from motor vehicles. ${ }^{216}$ The EPA had earlier claimed authority to regulate GHGs as an "air pollutant" in two agency general counsel memoranda and related affirmations to Congress. ${ }^{217}$ Under the new George W. Bush Administration, however, the EPA reversed itself, grounding this policy change in both a statutory abnegation strategy under which the EPA disavowed authority it had earlier claimed, as well as variables linked to presidential priorities. ${ }^{218}$

The Supreme Court rejected the EPA's interpretation of the statute as unsound. ${ }^{219}$ It also faulted the EPA for justifying that declination with reference

rigorous review of agency change if based on political factors, but deference if rooted in analysis of changing facts, expertise and "experience-based reasons," and workability. Id. at 1877-79.

211 See State Farm, 463 U.S. at 42.

${ }^{212}$ Id. (quoting Permian Basin Area Rate Cases, 390 U.S. 747, 784 (1968)).

213 Id. (emphasis omitted).

${ }^{214}$ Id. at 59 (Rehnquist, C.J., concurring in part and dissenting in part); see also id. ("As long as the agency remains within the bounds established by Congress, it is entitled to assess administrative records and evaluate priorities in light of the philosophy of the administration." (footnote omitted)).

215 See Massachusetts v. EPA, 549 U.S. 497, 510-14 (2007) (describing background of how EPA came to its decision not to regulate).

216 See id. at 505.

217 See id. at 510-14 (chronicling history of EPA’s interpretation of Clean Air Act).

218 Id. at 511-14 (describing EPA's change in policy).

${ }^{219}$ Id. at 528-35 (explaining why EPA's interpretation was untenable). 
to factors unrelated to the governing statute's criteria. ${ }^{220}$ The agency, the Court held, had to base its decision on the statutory criteria and relevant science, not extra-textual considerations and politics. It could not "rest[] on reasoning divorced from the statutory text." 221 The Court viewed the statute's broad reach and specificity regarding criteria for action as "constrain[ing]" the agency and the President-this was "the congressional design." 222 The agency had to make a "reasoned judgment" based on the science, "ground[ing] its reasons for action or inaction in the statute."223 The Court required the agency to base its choices on the contingencies made relevant by the Clean Air Act, namely whether the effects of GHGs and climate change caused "endangerment" within the meaning of the statute. 224

The more recent Fox decision and the 2016 Encino Motorcars case further flesh out the general framework for the permissible role of politics in agency policy change. ${ }^{225}$ In Fox, the agency had penalized a broadcaster based on a policy change regarding "fleeting use" of obscenities on television. ${ }^{226}$ The splintered opinions in Fox render difficult the determination of exactly what views regarding policy change garnered majority support. ${ }^{227}$ Change itself was stated not to trigger any significantly heightened standard of judicial scrutiny, but all agreed the agency would have to confront the old policy and explain the new policy.228 The Justices differed on what had to be weighed. Politics could play a part, and for Justice Scalia and an apparent majority aligned with him, agencies would have to "show that there are good reasons for the new policy."229 All Justices appeared to agree on this need for "good reasons."230

Justice Scalia's opinion, ostensibly for a majority but eliciting some pointed differences in the Justice Kennedy concurrence, also stated the following: the agency "need not demonstrate to a court's satisfaction that the reasons for the

${ }^{220}$ See id. at 532-35 ("The . . basis for EPA's decision ... rests on reasoning divorced from the statutory text.”).

${ }^{221} \mathrm{Id}$. at 532.

222 Id. at 533.

223 Id. at 534-35.

224 Id. at 534.

225 For a review of cases between State Farm and Fox discussing policy change and justification, see Kozel \& Pojanowski, supra note 7, at 129-32. Encino Motorcars post-dates that article's analysis, as do the recent policy change power claims reviewed here.

${ }^{226}$ See FCC v. Fox Television Stations, Inc., 556 U.S. 502, 505-10 (2009) (reviewing history of policy and agency action).

227 See Kozel \& Pojanowski, supra note 7, at 129 (highlighting reasons for splintered Fox opinion, especially differences between opinions of Justices Scalia and Kennedy, and characterizing result as "both thought provoking and deeply enigmatic").

${ }^{228}$ Fox, 556 U.S. at 514 (reaffirming holding in State Farm, which held that change in policy has to be explained by agency).

${ }^{229} \mathrm{Id}$. at 515.

230 The dissenters would have required more, but indicated no disagreement with the need for “good reasons.” See id. at 550 (Breyer, J., dissenting). 
new policy are better than the reasons for the old one; it suffices that the new policy is permissible under the statute, that there are good reasons for it, and that the agency believes it to be better ...."231 The opinions of Justice Scalia and Justice Kennedy both also acknowledged that because past policies will tend to change the status quo by engendering reliance interests and because prior agency actions often involve "factual findings," reviewing courts may have to look at a more developed record with a policy change than with a policy generated anew. ${ }^{232}$ The dissenters argued that agencies will always have to explain why the change was made, sharing the expectation that agencies must engage with prior facts and justifications. ${ }^{233}$

The Encino Motorcars decision, in a majority opinion by Justice Kennedy post-dating the death of Justice Scalia, linked this line of cases into one quite coherent exegesis that also lacked the uncertainty in Fox that was created by multiple opinions. Agencies making a policy change must, as always, "give adequate reasons" for their decisions. ${ }^{234}$ And that, as under typical "hard look review" articulated in State Farm, means an agency "must examine the relevant data and articulate a satisfactory explanation for its action including a rational connection between the facts found and the choices made."235 The Court again emphasized the need for assessment of any "reliance interests" and, quoting from Fox, stated that a " "reasoned explanation is needed for disregarding facts and circumstances that underlay or were engendered by the prior policy." "'236 An "[u]nexplained inconsistency" is a justification for holding a new agency action "arbitrary and capricious." 237 The Encino Motorcars Court notably did not quote or refine the Fox language about the agency change not needing to be "better" or that an agency's belief that the new policy was better would be enough, leaving its precedential weight and exact meaning still uncertain. ${ }^{238}$

${ }^{231}$ Id. at 515 (plurality opinion). This language appears to have garnered majority support, but Justice Kennedy's concurrence, which was needed to form a majority, more heavily emphasized the importance of factual justification and the need to check agencies from exercising "unbridled discretion" or ignoring contrary or "inconvenient” facts, especially since many agency actions are built on "factual findings.” Id. at 536-37 (Kennedy, J., concurring in part and concurring in the judgment). Encino Motorcars did so with even greater emphasis. See infra notes 234-241 and accompanying text.

232 See Fox, 556 U.S. at 515 (noting some cases in which change in policy will require more explanation than for initial rule).

${ }^{233}$ Id. at 551 (Breyer, J., dissenting).

234 Encino Motorcars, LLC v. Navarro, 136 S. Ct. 2117, 2125 (2016).

235 Id. at 2125 (quoting Motor Vehicle Mfrs. Ass'n of U.S., Inc. v. State Farm Mut. Auto. Ins. Co., 463 U.S. 29, 43 (1983)) (internal quotation marks omitted).

${ }^{236}$ Id. at 2126 (quoting Fox, 556 U.S. at 515-16 (plurality opinion)).

${ }^{237}$ Id. at 2125 (quoting Nat'l Cable \& Telecomms. Assn. v. Brand X Internet Servs., 545 U.S. 967, 981 (2005)) (alteration in original).

238 This language, however, is probably best read to embrace a deferential judicial attitude, not permission for unfounded agency action based merely on "belief." Combining the "good reasons" language and "believe it to be better" language is best read to require something akin 
Importantly, all of these cases share the requirement that agencies engage with the "facts and circumstances that underl[ay]" an earlier action. ${ }^{239}$ Such underlying facts and circumstances - which constitute a substantial part of what this Article collectively refers to as "contingencies"-will usually be repeatedly stated and linked to relevant law by agencies. These cases hence require substantial engagement with these contingencies by the later agency proposing the policy change. Such underlying facts, linked reasoning, and agency choices are virtually always discussed in referenced agency studies, the notice of proposed rulemaking, the preamble explaining the final agency rule choices, and agency responses to comments that must be provided to satisfy the requirements of reasoned decisionmaking. ${ }^{240}$ They are usually relevant to the assessment of the problem triggering agency regulation and also discussed in the agency's justification of the ultimate regulatory choice.

Hence, under the Court's express language, a subsequent agency effort to amend or roll back a previous regulatory policy will require engagement with these materials and related sources of contestation. "Unexplained inconsistency" is not permissible. ${ }^{241}$ As introduced above and analyzed in greater detail below, several major deregulatory proposals emphasize the possibility of policy change and a place for politics, but barely acknowledge the Supreme Court's persistent doctrinal emphasis over thirty years that an agency must address contingencies, namely underlying facts, science, circumstances, the record, and the agency's past reasoning.

\section{Additional Consistency Meta-Rules}

Several other administrative law meta-rules further constrain agencies, especially if they are tempted to deviate from past policy and practices but sidestep contrary evidence, arguments, or try to avoid direct declaration that they are doing so.

Perhaps most important is the agency's obligation to act consistently with its own commitments and practices. If an agency has, in a promulgated regulation, made a substantive or procedural choice, then it (along with affected stakeholders and courts as well) will, under the United States ex rel. Accardi $v$. Shaughnessy ${ }^{242}$ doctrine, have to abide by that commitment. ${ }^{243}$ Change, if it is

to "reasonable belief" in the proffered good reasons for the policy change, not proof that it is "better" than the initial policy. This makes it like most deference regimes, leaving agencies a space within which they can make and remake policy, if they provide adequate justifications. See Levin, supra note 16, at 573 (interpreting this language as consistent with Chevron, Brand $X$, and basic requirements of explanation under arbitrary and capricious review standards).

${ }^{239}$ Fox, 556 U.S. at 516.

${ }^{240}$ In fact, as explained below, during litigation, those justifications will be reiterated and likely sharpened. See infra notes 275-280 and accompanying text.

241 Encino Motorcars, 136 S. Ct. at 2126 (quoting Brand X, 545 U.S. at 981).

242347 U.S. 260 (1954).

${ }^{243}$ Id. at $265-68$. 
to be made, will need to be done at the same level of procedural formality. ${ }^{244}$ Until changed, the agency and all others will need to follow that rule-the promulgated regulation remains governing law until validly changed. ${ }^{245}$

Even without a promulgated regulatory commitment, agency practices and policies revealed or declared over time through other modes, especially adjudications, create the agency's working law and will also constrain an agency and require ongoing consistency or rational explanation for change. ${ }^{246}$ Only by confronting and, in a reasoned explanation, justifying some change can an agency deviate. ${ }^{247}$ Agencies cannot vacillate all over the map. ${ }^{248}$ They must treat similarly situated people alike. Should agencies be erratic, they will usually be held arbitrary in their policies. ${ }^{249}$ And, as clarified in the Allentown Mack Sales \& Service v. $N L R B^{250}$ decision, if an agency has declared one rule but perhaps deviated in practice, the Supreme Court has declared that the governing standard must be what is declared: "the rule announced [must be] the rule applied."251

As further revealed by Judulang $v$. Holder, 252 erratic agency actions in the form of overall inconsistency, or consistent inconsistency, will also lead to judicial rejection. ${ }^{253}$ Agency action cannot "hang[] on the fortuity of an

244 See Sierra Club v. EPA, 873 F.3d 946, 952 (D.C. Cir. 2017); Am. Mining Cong. v. Mine Safety \& Health Admin., 995 F.2d 1106, 1109 (D.C. Cir. 1993).

${ }^{245}$ Judicial rejection of postponement and stay strategies emphasize this point. See infra Section II.G.

246 Atchison, Topeka \& Santa Fe Ry. Co. v. Wichita Bd. of Trade, 412 U.S. 800, 807-08 (1973) (stating agency adjudications can "serve as vehicles for the formulation of agency policies" and that agency departing from established policy must "explain its departure from prior norms”); see also supra notes 11-12 and accompanying text (analyzing more modern cases involving court scrutiny of agencies changing policy over series of adjudicatory actions and related policy revelations).

247 See Atchison, 412 U.S. at 802, 807-08 (stating that there is "at least a presumption that those policies will be carried out best if the settled rule is adhered to" but then identifying permissible grounds for policy).

248 Todd D. Rakoff, Shaw's Supermarkets, Inc. v. NLRB-A First Circuit Opinion, 128 HARV. L. REV. 477, 478-79 (2014) (discussing then-Judge Breyer's opinion in Shaw's Supermarkets, Inc. v. NLRB, 884 F.2d 34, 37, 41 (1st Cir. 1989), and its call for agencies to "follow[] or consciously change[]" policy but not "have one rule for Monday, another for Tuesday” (citations omitted)).

249 See Encino Motorcars, LLC v. Navarro, 136 S. Ct. 2117, 2125 (2016) (“But where the agency has failed to provide even that minimal level of analysis, its action is arbitrary and capricious ....”).

250522 U.S. 359 (1998).

251 Id. at 375.

252565 U.S. 42 (2011).

253 See Id. at 61 (emphasizing that "longstanding capriciousness receives no special exemption from the APA" and finding that "BIA has repeatedly vacillated in its method for applying § 212(c) to deportable aliens”). 
individual official's decision.”254 The Court condemned the agency tribunal (the Board of Immigration Appeals) for lacking decisional criteria connected to "the goals of the deportation process or the rational operation of immigration laws," making it a "sport of chance." 255 Such agency policy, or really lack of a consistent policy, was hence illegal arbitrary and capricious action under the APA. ${ }^{256}$

In addition, a related meta-rule is evident in the practices of government rulemaking itself. Agency rulemakings must give all fair notice of what is proposed. ${ }^{257}$ A final rule that differs too much from a proposal can be rejected as not a "logical outgrowth" of the proposal and remanded for more adequate notice-and-comment opportunities. ${ }^{258}$ Courts will also decline to defer to an agency's newly declared policy if it goes beyond what the public would have expected and addressed in comments. This is especially evident in recent preemption case law. Agencies that claim preemptive impact of federal approvals or actions in litigation or possibly regulatory preambles will be ignored or reviewed with no deference if that preemption claim is inconsistent with the earlier noticed commitments. ${ }^{259}$ Hence, a vague or conclusory proposal to change policy, or major changes between a proposal and final rule, can also lead to rejection of a changed policy. Yet again, courts expect and police for agency consistency with procedural norms and with the agency's stated commitments or proposals.

\section{E. Reasoned Decisionmaking as a Constraint}

Perhaps most importantly, the long-established requirement that agencies engage in "reasoned decisionmaking" provides a brake on erratic or unexplained sudden change, or actions that disregard statutory criteria and process. The obligation of agencies to engage in reasoned decisionmaking is among the most

254 Id. at 58.

255 Id. (citing Di Pasquale v. Karnuth, 158 F.2d 878, 879 (2d Cir. 1947)) (internal quotation marks omitted).

256 See id. at 59.

257 See Chocolate Mfrs. Ass’n v. Block, 755 F.2d 1098, 1105 (4th Cir. 1985).

258 See id.; Jennifer Nou \& Edward H. Stiglitz, Strategic Rulemaking Disclosure, 89 S. CAL. L. REV. 733, 744-46 (2016) (characterizing modern "logical outgrowth" doctrine as requiring that proposals "be detailed and specific enough to alert potential commentators," including initial disclosure of "key data and studies they relied upon").

259 See Wyeth v. Levine, 555 U.S. 555, 581 (2009) (rejecting FDA claim that its less stringent FDA actions could preempt stricter state requirements, but in opinion focusing on lack of notice of such plan); Gonzales v. Oregon, 546 U.S. 243, 275 (2006) (rejecting Attorney General's claim of power without express statutory authority, specific statutory allocations of regulatory authority, and no preceding notice or deliberation over such power claim). Some have analyzed these rejections as partly attributable to lack of agency opportunities for political input. See Bressman, supra note 69, at 775-89. For a discussion of how courts reviewing agency claims of preemptive impact utilize a variant of "hard look review," see Buzbee, supra note 85, at 1547-80. 
durable of administrative law tenets due to its roots in several overlapping facets of the APA and the doctrine framing judicial review of agency action. ${ }^{260}$ This term and the obligations it imposes involve an overlapping amalgam of statutory interpretation frames, Chevron Step Two "reasonableness" review, the fleshing out of arbitrary and capricious review and, relatedly, what "hard look review" requires of courts and agencies subjected to judicial review, especially regarding a policy change. ${ }^{261}$

First, reasoned decisionmaking law establishes-as do virtually all administrative law doctrines - that all agency decisionmaking must be framed by what governing statutes identify as relevant goals, criteria, and process. ${ }^{262}$ Any failures to abide by those statutory mandates will flunk. Citizens to Preserve Overton Park, Inc. v. Volpe 263 ("Overton Park") and State Farm both require agencies to base their decisions on the "relevant factors."264 Likewise, in rejecting the agency's explanation for turning down a petition, the Supreme Court in Massachusetts v. EPA emphasized that the agency had to base its actions (or choices not to act) on assessments called for by statutory criteria. ${ }^{265}$ By so rejecting reliance on non-statutory political considerations, agency latitude to follow the political winds or expediency was constrained. As others have noted, the case called for a more expertise-based mode of decisionmaking that required attention to facts made relevant by the governing statute. ${ }^{266}$

Second, SEC v. Chenery Corp. (Chenery I) ${ }^{267}$ requires that agencies provide a reasoned contemporaneous explanation when they act and then consistently

${ }^{260}$ Much of this doctrine is rooted in judicial constructions of the APA's judicial review provisions. 5 U.S.C. $\S \S 701-706$ (2012).

${ }^{261}$ Motor Vehicles Mfrs. Ass'n v. State Farm Mut. Auto. Ins. Co., 463 U.S. 29, 41-44 (1983) (linking cases and explaining contours of required agency explanation and judicial review). For an analysis of, and argument in favor of, the overlap of Chevron Step Two reasonableness review, State Farm "hard look review," and the need for courts to distinguish language interpretation choices from factually-contingent and expertise-based derivation of policy governed by "reasoned decisionmaking" precedents, see Sharkey, supra note 70 at 2384, 2394-96.

262 Massachusetts v. EPA, 549 U.S. 497, 533 (2007), similarly confirms the importance of reasoned decisionmaking by emphasizing the agency obligation to ground its actions in assessment of factors in the statutory text. See supra note 8 and accompanying text.

263401 U.S. 402 (1971).

264 State Farm, 463 U.S. at 43 (linking Overton Park and other precedents and factors that are now referred to as heart of "hard look review").

${ }^{265}$ Massachusetts v. EPA, 549 U.S. at 532-33 (stating agency cannot rely on "reasoning divorced from the statutory text" and rejecting political "laundry list of reasons not to regulate”).

266 See Freeman \& Vermeule, supra note 8, at 54, 66, 99-101 (describing Massachusetts v. EPA as "expertise forcing" and constraining influence of politics); Watts, supra note 17, at 21-22 (same).

267318 U.S. 80 (1943). 
stick with that explanation. ${ }^{268}$ Agencies in any rulemaking thus cannot strategically adjust their rationales to fend off attacks, but will also have to amplify on the reasonableness of the initial explanation. ${ }^{269}$ Hence, an agency considering a policy change will not only confront an earlier initial agency choice that necessarily grapples with underlying contested issues and facts, but also later consistent, though likely more fulsome, explanation defending that policy in court. 270

Furthermore, Overton Park creates similar incentives. ${ }^{271}$ It authorizes more intrusive judicial review of agency actions, and possibly even court testimony and cross examination of regulators, when an agency does not adequately explain its choices initially or make clear reference to a supportive record. ${ }^{272}$ To avoid such judicial probing, agencies are usually careful to provide findings or explicitly stated rationales that engage relevant law, comments, and facts. ${ }^{273}$ Because stakeholders know the importance of an agency getting its initial choice right, all will make sure that studies, comments, data, and supporting submissions to the agency (and later, courts) weave an additional, but still consistent, supportive tapestry of rationales and evidence. ${ }^{274}$

${ }^{268}$ Id. at 90 .

269 See Atchison, Topeka \& Santa Fe Ry. Co. v. Wichita Bd. of Trade, 412 U.S. 800, 807 (1973) (stating that courts "must rely on the rationale adopted by the agency if we are to guarantee the integrity of the administrative process").

270 Justice Kennedy's Fox concurrence appears to be describing this sort of agency amplification of the factual grounds for an initial action. FCC v. Fox Television Stations, Inc., 556 U.S. 502, 537 (2009) (Kennedy, J., concurring in part and concurring in the judgment) (explaining why agency record "may be much more developed").

271 See Citizens to Preserve Overton Park, Inc. v. Volpe, 401 U.S. 402, 417-19 (1971).

272 See id. at 419-20.

273 See generally Peter L. Strauss, Revisiting Overton Park: Political and Judicial Controls Over Administrative Actions Affecting the Community, 39 UCLA L. REV. 1251 (1992) (discussing politics influencing Overton Park battle and incentives created by Court's decision).

274 Vermont Yankee Nuclear Power Corp. v. Natural Resources Defense Council goes further, in the NEPA context, by requiring commenters to make clear their views or later be foreclosed. See Vt. Yankee Nuclear Power Corp. v. Nat. Res. Def. Council, Inc., 435 U.S. 519, 554 (1978). NEPA-specific "hard look" obligations now overlap in logic and language with "reasoned decisionmaking" requirements and "hard look review" as embraced in State Farm. See, e.g., Marsh v. Or. Nat. Res. Council, 490 U.S. 360, 374-78 (1989) (stating that NEPA requires agencies to take "hard look" at environmental effects of planned action and citing APA precedents for roots of judicial review under NEPA); WildEarth Guardians v. Jewell, 738 F.3d 298, 302-03 (D.C. Cir. 2011) (describing NEPA as "essentially procedural” statute that obligates agency to consider every significant impact of proposed action and requires "informed decision making”); Powder River Basin Res. Council v. U.S. Bureau of Land Mgmt., 37 F. Supp. 3d 59, 71 (D.D.C. 2014) (stating that reviewing court must ensure that agency acting under NEPA has examined relevant data, articulated rational connection between facts found and choices made, and that agency made no “clear error of judgment”). 
Relatedly, reasoned decisionmaking scrutiny often focuses on how the agency responded not just to disputes over statutory interpretation, but disputes over onthe-ground realities such as relevant risks, business practices, science, costs, and the like. An agency that ignores salient issues or sweeps away cogent challenges and criticisms faces quick and easy rejection in the courts. ${ }^{275} \mathrm{~A}$ well-counseled agency, assuming the agency has a firm legal and factual basis for its regulatory choice, will therefore directly engage with its challengers' and supporters' key claims and issues in dispute and explain why the agency's action is well justified. ${ }^{276}$ This will occur both within a rulemaking procedure and again in the courts.

This process of contestation and cogent response results in a dialectical, iterative sort of tightening of explanations due to close engagement with contested claims and arguments. ${ }^{277}$ Much as reply briefs often provide the most incisive analysis, fiercely challenged regulations result in ever more cogent agency explanations that virtually always engage and reject the very facts and claims that later change advocates embrace.

This hybrid of substantive and process review of an agency's initial regulation results in a hefty body of reason-giving and related identification of which studies, facts and related policy predictions matter. When, at a later time, a president or agency seeks to reverse course and jettison the old rule, all of those contingent facts and reasoning will need to be engaged. It is a near certainty that the circumstances in Encino Motorcars will arise again, such that changes will require substantial agency explanation. Not only are reliance interests likely, but "facts and circumstances that underlay" the initial action will also be many and will have been repeatedly identified, articulated, and sharpened during the regulatory and later adversarial process. ${ }^{278}$

${ }^{275}$ For a discussion of lead cases on such rejections in the setting of policy changes, see infra Sections II.G, II.H. Judicial rejections of agency actions due to lack of adequate notice or agency failures to respond to salient comments and criticism are legion. See, e.g., Am. Radio Relay League, Inc. v. FCC, 524 F.3d 227, 236-41 (D.C. Cir. 2008) (rejecting agency action for failure to provide adequate notice regarding studies relied on and failure to respond to comments); Owner-Operator Indep. Drivers Ass'n v. Fed. Motor Carrier Safety Admin., 494 F.3d 188, 199-206 (D.C. Cir. 2007) (faulting agency for failing to provide adequate notice, especially for undisclosed change in methodology); Int'l Ladies' Garment Workers' Union v. Donovan, 722 F.2d 795, 813-18 (D.C. Cir. 1983) (remanding regulation because agency failed to explain rejection of alternatives identified in salient comments made by state officials, and discussing State Farm's confirmation of agency obligation to explain its choices).

${ }^{276}$ Scholarship on regulatory ossification links such frozen or slowly changing regulation to the rigor of such review. See supra note 70 and accompanying text.

277 See generally Emily Hammond Meazell, Deference and Dialogue in Administrative Law, 111 CoLUM. L. REV. 1722 (2011) (analyzing how sequences of cases over same or linked agency actions can lead to agency-court dialog providing deliberative benefits and sharpening of analysis).

${ }^{278}$ FCC v. Fox Television Stations, Inc., 556 U.S. 502, 516 (2008). 
An agency pursuing a policy change will thus have to confront outside stakeholders' submissions and explain its own rejection of materials, explanations, and arguments that it previously identified as justifying a contrary earlier choice. ${ }^{279}$ Even if the agency hopes somehow to avoid such engagement, stakeholders supportive of the initial policy will put the agency's own earlier words and logic back before it and again later before the courts. With such comments and arguments back before it, the agency will need to respond, leave no "unexplained inconsistency," and justify its choice with "good reasons" or face judicial rejection. ${ }^{280}$

Policy change is thus possible, but an agency that proposes a policy change while also trying to sidestep science, studies, data, and the agency's own past explanations will, due to these linked facets of reasoned decisionmaking's requirements, be vulnerable to judicial rejection. Because few agencies will set themselves up for failure, cases involving agency policy change and addressing inadequate explanation and engagement are rarer than might be expected. Still, their conclusions are remarkably consistent. 281

\section{F. Agency Record and Deliberative Conformity}

One sometimes overlooked facet of consistency doctrine is how agencies, in a sequence of deliberations leading to action, will create a constraining set of materials, especially where they are based on conclusions about evidence, data, or science. Much of this law arises out of the early doctrinal development of administrative law, building on the declaration in Universal Camera Corp. $v$. $N L R B^{282}$ of what "substantial evidence" review requires. ${ }^{283}$ Courts had to devise rules guiding the obligations of agencies and courts where administrative law judges or other subordinate agency officials assess evidence underpinning an action that then moves up the regulatory hierarchy.

Although the nuances of this early law are of little significance to this Article, one central tenet remains settled and important: agency officials cannot disregard the evidentiary, science, or data-based judgments generated by, and

279 Justice Kennedy notes this. Id. at 535, 537 (Kennedy, J., concurring in part and concurring in the judgment) (discussing "reasoned explanation” obligation, and stating that "agency cannot simply disregard contrary or inconvenient factual determinations that it made in the past, any more than it can ignore inconvenient facts when it writes on a blank slate").

280 See supra Section II.C (discussing this element of Fox and Encino Motorcars).

281 See infra Sections II.G, II.H (discussing cases of judicial rejection of agency policy changes).

282340 U.S. 474 (1951).

${ }^{283}$ Id. at 491 (clarifying that courts must look at supportive and contrary evidence, and also indicating that reviewing courts need to include subordinate administrative judge's finding in evidence assessed). This logic has been applied to tax court decisions. See Ballard v. Comm'r, 544 U.S. 40, 59 (2005) (holding that record on appeal must include special tax court judges' reports). 
then moving through, the agency's process and hierarchy. ${ }^{284}$ Some types of determinations may be binding while others may not be, but senior regulators cannot wholly disregard what was generated earlier by hierarchical subordinates. Here too, like the requirements of reasoned decisionmaking, agency decisionmakers must engage with what came before.

The Alaska Department of Environmental Conservation v. EPA ${ }^{285}$ case is illustrative, although with a state-federal wrinkle. The Supreme Court upheld the EPA's power to issue orders declaring that a state air pollution permit was illegally lax, in part because career state regulators, and then EPA officials, documented better methods of pollution control. State political leadership had embraced a more relaxed approach with little factual support. ${ }^{286}$ The Court, like the EPA, looked at the underlying regulatory stringency with close attention to the findings of regulatory subordinates and how senior regulators grappled with that information. ${ }^{287}$ The EPA and the Supreme Court rejected the unfounded politicized state embrace of laxity. 288

Similarly, and also in a federalism-laden case, the Supreme Court in Wyeth $v$. Levine ${ }^{289}$ rejected FDA's new claim that its regulatory approvals preempted common law regimes, but without the agency offering advance public notice of such a plan. ${ }^{290}$ The Court noted the agency's failure to notify the world of this possible claim of preemptive impact, as well as the agency's failure to explain what justified the change in policy, failure to engage contrary views, and other lack of factual and reasoned justification. ${ }^{291}$

\section{G. The Losing Track Record of Poorly Explained Policy Changes}

Several key precedents, in applying these intertwined bodies of doctrine, illuminate both what agencies can and should do in changing policies, but also illuminate grounds for judicial rejection. These precedents also reveal that the rigor with which administrations justify their policy changes shapes the judicial reception. Courts take this body of doctrine seriously.

\footnotetext{
284 See, e.g., Pollinator Stewardship Council v. EPA, 806 F.3d 520, 532 (9th Cir. 2015) (rejecting EPA licensing use of pesticide due to failure to reconcile earlier statements about needed additional analysis and final action taken without such data).

285540 U.S. 461 (2004).

${ }^{286}$ See id. at 484-88 (contrasting professional staff's conclusions and contrary lax decision by heads of state agency and noting lack of record support for business hardship claim seeking permit in Court opinion upholding EPA's powers to reject permit).

287 Id.

288 See id. at 485.

289555 U.S. 555 (2009).

${ }^{290}$ Id. at 581. For a discussion of how Wyeth embraces a variant of "hard look review" and emphasizes need for adequate agency process and engagement with claims about impacts of policy choices, see Buzbee, supra note 85, at 1566-73.

291 See Wyeth, 555 U.S. at 563-581.
} 
Both advocates of politically-driven policy change and critics of the alleged ease of change, such as Justice Gorsuch, refer to the Chevron case to confirm their views. ${ }^{292}$ It is true that the Supreme Court in Chevron upheld an agency's (the EPA's) policy change, and even praised agency policy reconsideration as something an agency "must" do. ${ }^{293}$ However, the change at issue-allowing states regulating "stationary sources" to utilize a facility-wide bubble strategy that allowed internal pollution trading instead of a stack-by-stack regulatory approach-actually was far from radical and was not justified based on some version of presidential power to rule by fiat. ${ }^{294}$ The agency utilized a notice-andcomment process, still pursued cleaner air, and still was regulating the sources. ${ }^{295}$ The agency, and later the Supreme Court, justified the new bubble strategy as appropriately "reconciling" dueling goals of the Clean Air Act, namely clean air and economic growth. ${ }^{296}$ Moreover, the agency and commenters directly engaged with the earlier approach in explaining the new bubble strategy, offered economic analyses and observations about how previous stack-by-stack regulation could deter operational improvements, and explained how such a bubble strategy should lead to more cost-effective regulation. ${ }^{297}$ The case involved changed means to achieve a consistently defined end, with careful hewing to the statute's relevant factors, and basis in logic and the record for the choice. A rule was replaced with another rule.

As a case upholding a policy change, therefore, Chevron does provide guidance. But it is rooted in far more than just identification of a linguistic ambiguity or presidential leanings. ${ }^{298}$ In upholding the new approach under what today would be called Chevron Step Two, the Court and agency both examined the rationales for the old and new policy, and looked for and found good reasons for the new policy. Its logic and conclusions neatly fit within the consistency law frameworks set forth years later in Fox and Encino Motorcars, although

292 See, e.g., Gutierrez-Brizuela v. Lynch, 834 F.3d 1142, 1153-54 (10th Cir. 2016) (Gorsuch, J., concurring).

293 Chevron U.S.A., Inc. v. Nat. Res. Def. Council, Inc., 467 U.S. 837, 863-64 (1984).

294 See id. at 855-66 (reviewing policy rationales, incentives for new investments created by policy options, economics literature, record support, and legislative history as part of Court's upholding of EPA's bubble rule as reasonable).

295 Id.

296 Id. at 865.

297 Id. at 863; see also supra note 26 and accompanying text.

298 The Court did identify presidential electoral accountability as among the grounds for deference to the agency's new policy. See Chevron, 467 U.S. at 865 ("While agencies are not directly accountable to the people, the Chief Executive is, and it is entirely appropriate for this political branch of the Government to make such policy choice.”). Mead later emphasized the quasi-democratic accountability of notice-and-comment rulemaking as a usual precondition for Chevron deference. See United States v. Mead Corp., 533 U.S. 218, 227-31 (2001). 
those two cases' policy shifts met varied fates due to the inconsistent rigor of their agencies' change explanations. ${ }^{299}$

State Farm is at the other end of the lessons spectrum, illustrating what agencies absolutely cannot do in changing policy. ${ }^{300}$ The abandonment by the National Highway Traffic and Safety Administration ("NHTSA") of the previous regulatory requirement of seatbelts or airbags, with no explanation for the abandonment of the airbag alternative, was firmly rejected. ${ }^{301}$ Similarly, the agency's poor logic in abandoning the requirement of seatbelts also led to rejection. ${ }^{302}$

Agencies still sometimes fail to heed the guidance provided by these cases, seeking to change policy but without full engagement with the earlier rules' rationales, evidence, and finalized requirements. Courts reject such agency actions. Several appellate cases addressing regulatory policy shifts under several different presidential administrations offer such analysis after Fox and even in one case after Encino Motorcars as well.

For example, in North Carolina Growers' Ass'n, Inc. v. United Farm Workers', ${ }^{303}$ the Fourth Circuit rejected as unlawful an action during the Obama Administration by the Department of Labor. ${ }^{304}$ The Department sought to suspend current regulations and return to earlier regulations, while also trying to restrict comments so they would not focus on the substance of the regulations to be abandoned or the overall regulatory result. ${ }^{305}$ The agency lost across the board. ${ }^{306}$ First, it made no difference that the agency claimed to be "reinstating" an old rule; a rule change was a rule change and had to surmount the same

${ }^{299}$ Fox involved a new interpretation of a broad authority grant, and a "value judgment" about policing of obscenity on television. See FCC v. Fox Television Stations, Inc., 556 U.S. 502, 512 (2009). The Court upheld the policy shift, noting how the FCC had engaged with its past policy and explained its new choice. Id. at 513-16. Encino Motorcars rejected the Department of Labor's policy shift, emphasizing the need for full and forthright agency acknowledgment of its past policies and explanation for a policy shift. Encino Motorcars, LLC v. Navarro, 136 S. Ct. 2117, 2123-24, 2126-27 (2016).

300 Motor Vehicles Mfrs. Ass’n v. State Farm Mut. Auto. Ins. Co., 463 U.S. 29 (1983).

${ }^{301} \mathrm{Id}$. at 46-51.

${ }^{302} \mathrm{Id}$. at 51-57 (reviewing and rejecting seatbelt reversal logic and factual basis); see also GOLDEN, supra note 74, at 40-60 (exploring internal NHTSA dynamics leading to this poorly pursued policy change, with political appointees pursuing pre-ordained outcome and failing to allow agency professionals input or opportunity to strengthen deregulatory shift).

303702 F.3d 755 (4th Cir. 2012).

${ }^{304}$ Id. at 759 ("[W]e hold that the district court did not err in invalidating the Department's action on the ground that it was arbitrary and capricious.”).

305 See id. at 760-62.

306 Id. at 759. 
process to be effective. ${ }^{307}$ The court also restricted the agency justification to that offered at the time, as required by Chenery I. $^{308}$

Of greatest importance to this Article, the court in North Carolina Growers stated that the agency's effort to constrain comment content while trying to change a policy violated both the APA's notice-and-comment provisions and the core "reasoned decisionmaking" requirements set forth by the Supreme Court in the State Farm case. ${ }^{309}$ Because an agency has to "consider ... important aspect[s] of the problem" underlying the regulation, it must allow comment on and respond to "relevant, significant issues raised during those proceedings." 310 The court further faulted the agency for refusing to receive comments on issues "integral" to sorting out the rationales for the actions under reconsideration. This denied commenters the "meaningful opportunity" for comment required by the APA and hence "ignored important aspects of the problem." 311

In a concurrence, Judge Wilkinson offered a concise but powerful essay. ${ }^{312}$ He distinguished between an agency's power to revisit a policy-a "seesaw" he said was permissible since "[n]o one expects agency views to be frozen in time"-and "changes in course" that "cannot be solely a matter of political winds and currents." 313 A policy "pivot" must be "accomplished with at least some fidelity to law and legal process." 314 If not, then "whim and caprice" will rule and "business planning" will be disrupted. ${ }^{315}$ Agency change must be accompanied by "a measure of deliberation and, hopefully, some fair grounding in statutory text and evidence."316 To allow the agency's sidestepping of comment and engagement with the record would "generate a blueprint for agency unaccountability.”317 Judge Wilkinson's formulation closely tracks the logic and requirements of the Supreme Court's consistency cases, acknowledging the change power but pointing out why policy change must be accompanied by full and adequate process, show engagement with past facts and rationales, and find justification in the law's text and relevant evidence. Unlike Justice Gorsuch, he views the prevailing law as not allowing such policy shifts without full participation, engagement, and agency justification.

\footnotetext{
307 See id. at 765 ("We are not persuaded by the Farm Workers' textual argument that, under the APA, the act of 'reinstating' a rule does not qualify as 'formulating' a rule.”).

${ }^{308}$ Id. at 767-68 ("We consider an explanation for good cause that the agency has advanced at the time of the rule making.").

${ }^{309}$ Id. (citing Motor Vehicles Mfrs. Ass’n v. State Farm Mut. Auto. Ins. Co., 463 U.S. 29, 23 (1983)).

${ }^{310}$ Id. at 769.

${ }^{311}$ Id. at 769-70 (citations omitted) (internal quotation marks omitted).

${ }^{312}$ Id. at 771-72 (Wilkinson, J., concurring).

${ }^{313}$ Id. at 772 .

${ }^{314}$ Id.

${ }^{315} I d$.

${ }^{316} I d$.

${ }^{317} I d$.
} 
Similarly, in the Public Citizen Health Research Group v. Tyson ${ }^{318}$ case from the Reagan Administration, the D.C. Circuit firmly rejected an Occupational Safety and Health Administration ("OSHA") action for violating several fundamental tenets of consistency doctrine, emphasizing an agency's obligation to engage with salient issues and choices it or stakeholders raised. ${ }^{319}$ The agency had proposed, but ultimately did not issue, a short-term workplace exposure standard for ethylene oxide. ${ }^{320}$ In explaining its own precedents as applied to the Occupational Safety and Health Act's "substantial evidence" standard, the court emphasized the agency obligation "to identify relevant factual evidence, to explain the logic and the policies underlying any legislative choice, to state candidly any assumptions on which it relies, and to present its reasons for rejecting any significant contrary evidence and argument." ${ }^{21}$ Even though the agency choice involved the cutting edge of knowledge, and imperfect science and predictive judgment, the changed agency choice had to be rejected because the agency "simply [did] not exercise[] its expertise." 322 By failing to engage with key questions, OSHA had violated the State Farm mandate that agencies cannot "entirely fail[] to consider an important aspect of the problem."323

\section{H. The Trump Administration Regulatory Shortcuts and Judicial Rejections}

In several of the Trump Administration's early regulatory actions, agencies similarly sought to sidestep engagement with evidence and rationales underpinning earlier finalized actions, usually promulgated notice-and-comment regulations. These agencies proposed in one form or another to stay, suspend, or postpone these earlier finalized regulations or in other ways sought a shortcut to achieve deregulation. ${ }^{324}$ They also sometimes intimated that they might later issue a new rule. In seeking to undo earlier finalized regulations in this severalstep manner, they also sought to limit comment. This appears to be a strategy pursued in over a dozen regulatory settings. ${ }^{325}$ By mid-2018, this strategy

318796 F.2d 1479 (D.C. Cir. 1986).

319 Id. at 1481, 1507.

320 See id. at 1482.

${ }^{321}$ Id. at 1485 (quoting United Steelworkers v. Marshall, 647 F.2d 1189, 1207 (D.C. Cir. 1980)) (internal quotation marks omitted).

${ }^{322} \mathrm{Id}$. at 1505.

${ }^{323}$ Id. at 1507 (quoting Motor Vehicles Mfrs. Ass’n v. State Farm Mut. Auto. Ins. Co., 463 U.S. 29, 43 (1983)) (internal quotation marks omitted).

324 See supra notes 89-97 and accompanying text.

325 See, e.g., Dlouhy \& Levin, supra note 97. The EPA's 2018 promulgation of an "applicability date" rule suspending the effect of the still-valid Clean Water Rule utilized a similar strategy. See supra notes 128-129 and accompanying text. Just before this Article's publication, a federal district court invalidated the "applicability date” regulation-referred to as the Suspension Rule-due to splintering of the regulatory process, failures to provide "meaningful opportunity for comment," and failures to comply with the APA, including minimal engagement with science underpinning the Clean Water Rule. S.C. Coastal 
resulted in numerous judicial rejections similarly concluding that such sidestepping of earlier regulatory substance, rationales, and basic APA procedures is an illegal circumvention of fundamental administrative law precepts.

These cases substantially followed the reasoning of decisions from the Reagan era that rejected several agencies' efforts to postpone or sidestep the effect of finalized regulations, but without full use of a new notice and comment process. ${ }^{326} \mathrm{~A}$ few are summarized here. ${ }^{327}$

After the EPA in 2017 granted industry stay and reconsideration petitions regarding a final promulgated rule regulating methane leaks from oil and gas operations, the D.C. Circuit in Clean Air Council v. Pruitt ${ }^{328}$ ("Clean Air Council”) found that the agency's action suffered from several illegalities. ${ }^{329}$ It ran afoul of the particular statutory requirements of the Clean Air Act ("CAA"), the implications of the underlying record, and administrative law principles. 330 The agency could not rely on a special CAA provision authorizing reconsideration and stays for overlooked issues, which were both raised and

Conservation League v. Pruitt, No. 2:18-cv-00330, slip op. at 6-18 (D.S.C. Aug. 16, 2018); see also infra notes 329-337 and accompanying text.

326 See Envtl. Def. Fund v. Gorsuch, 713 F.2d 802, 808, 814-18 (D.C. Cir. 1983) (rejecting agency's postponements and deferrals of regulatory obligations under finalized regulation as inconsistent with obligation to change rule with rule, and discussing cases addressing same issue and reaching same result).

327 Several notable other 2017 and 2018 rejections of deregulatory actions involving assorted shortcuts from usual full notice-and-comment process are not discussed in the text. See Pineros Y Campesinos Unidos Del Noroeste v. Pruitt, 293 F. Supp. 3d 1062, 1066-67 (N.D. Cal. 2018) (rejecting pesticide application regulation delay as unlawful and emphasizing need to allow comment on substantive change to finalized regulation); Sierra Club v. Pruitt, 293 F. Supp. 3d 1050, 1057-61 (N.D. Cal. 2018) (rejecting yearlong delay in implementation of formaldehyde emissions regulation as violation of enabling act and APA); Pennsylvania v. Trump, 281 F. Supp. 3d 553, 570-76 (E.D. Pa. 2017) (rejecting for APA and statutory violations multi-agency effort to create expansive new exemptions from Affordable Care Act contraceptive coverage mandate but without providing any advance notice-andcomment process). One decision linked to the BLM methane waste prevention rule issued a judicial stay of the rule's "phase-in provisions" during the pendency of a timely challenge to that rule and in light of a pending substantive revision expected to be completed "within a period of months.” Wyoming v. U.S. Dept. of the Interior, No. 2:16-cv-0280, slip op. at 10 (D. Wyo. Apr. 4, 2018). The rejection of the Suspension Rule in South Carolina Coastal Conservation League v. Pruitt includes text and footnote collection of judicial rejections of other "hastily enacted rules." S.C. Coastal Conservation League, slip op. at 11-12 \& n.2.

328862 F.3d 1 (D.C. Cir. 2017).

${ }^{329}$ Id. at 14 (holding that EPA's decision to grant industry stay was arbitrary and capricious).

${ }^{330}$ See id. (holding that administrative record made clear that "industry groups had ample opportunity to comment” during notice-and-comment period and Clean Air Act "did not authorize” EPA to issue stay). 
addressed. ${ }^{331}$ Petitioners and the agency also could not claim some agency final rule surprise flunking "logical outgrowth" requirements as justification for a stay. ${ }^{332}$ Furthermore, the Clean Air Council court stuck with long established law that an agency cannot "suspend" a rule's compliance deadlines or alter the effective date because "such orders are tantamount to amending or revoking a rule." 333 Any such amendment or revocation required a new notice-andcomment process because "an agency issuing a legislative rule is itself bound by the rule until that rule is amended or revoked[,]" and that would require noticeand-comment. ${ }^{334}$ To allow such a stay of a rule would be contrary to APA consistency and rule of law norms, would lack a statutory basis, and could only be upheld on grounds contemporaneously offered by the agency. ${ }^{335}$ None were offered that were legally sufficient. The stay was therefore itself arbitrary and capricious. ${ }^{336}$ The court acknowledged that policy change remained a possibility, but quoted the Supreme Court's Fox opinion and its call for "good reasons" for a change. ${ }^{337}$

Likewise, the D.C. Circuit later rejected with similar logic and substantially overlapping statutory analysis another CAA-based rule, in this case an effort to promulgate a "Delay Rule" to delay the effective date of the 2017 "Chemical Disaster Rule" for twenty months. ${ }^{338}$ The court found that the statute set forth constraining and specific conditions for delayed regulatory effectiveness and allowed only a limited three month delay, both of which were violated by the EPA's Delay Rule. 339 The court also faulted the EPA for not engaging with its own earlier "determinations and findings," or its new "departure from its [earlier] stated reasoning." 340 It thereby violated its "reasoned decisionmaking" obligations under consistency cases and other foundational APA precedents, rendering its action arbitrary and capricious. ${ }^{341}$

${ }^{331}$ Id. at 9-14 (discussing four issues raised during notice-and-comment period and observing that EPA incorporated comments directly into final rule).

${ }^{332}$ Id. (holding that EPA's initial final rule proposed for change did not fail logical outgrowth test).

${ }^{333} \mathrm{Id}$. at 6.

${ }^{334}$ Id. at 9 (quoting Nat'l Family Planning \& Reprod. Health Ass'n v. Sullivan, 979 F.2d 227, 234 (D.C. Cir. 1992)) (internal quotation marks omitted).

${ }^{335}$ Id. (holding that EPA did not establish it had inherent authority to issue stay of final rule under statute).

336 Id. at 14.

${ }^{337}$ Id. (quoting FCC v. Fox Television Stations, Inc., 556 U.S. 502, 515 (2009)) (internal quotation marks omitted).

338 Air All. Hous. v. EPA, No. 17-1155, slip op. at 19-36 (D.C. Cir. Aug. 17, 2018).

${ }^{339}$ Id. at 19-27 (reviewing statutory limitations on delaying effectiveness of initial rule, even if done through another rulemaking).

${ }^{340}$ Id. at 27-36.

${ }^{341}$ Id. at 31-37; see also League of United Latin Am. Citizens v. Wheeler, 899 F.3d 814, 829 (9th Cir. 2018). The Wheeler case reviewed and rejected another accelerated EPA regulatory action-a reversal of course by the EPA in deciding not to regulate chlorpyrifos. 
Becerra v. United States Department of the Interior, ${ }^{342}$ a district court opinion, involved a similar agency attempt to stay and not enforce a final regulation through a "postponement." 343 The government's lawyers heavily relied on Section 705 of the APA, a provision that authorizes, in specified settings, an agency to "postpone the effective date of action taken by it . ..."344 But following one earlier decision addressing this argument, the court held that this provision by its terms does not apply to a finalized rule that has "gone into effect." 345

The Becerra court, like Clean Air Council and Air Alliance Houston v. $E P A,{ }^{346}$ drew support from the same rule of law and administrative regularity principles reviewed above: the judge found "no precedent or legislative history to support a Congressional delegation of such broad authority to bypass the APA repeal process for a duly promulgated regulation." 347 To allow the Department's postponement would undercut fundamental tenets about the binding nature of regulations and the need for a new rulemaking to undo an earlier rule. ${ }^{348}$ Otherwise, an agency could, with lengthy postponements in effect, abandon a rule but without opportunities for "comment on the wisdom of repeal," or agency justification of a policy change. ${ }^{349}$

A fourth decision similarly faulted a regulatory stay effort by the Bureau of Land Management as an illegal effort to circumvent the binding nature of finalized regulations. ${ }^{350}$ Judge Elizabeth LaPorte's decision was especially

Under EPA's reversal, it declined to revoke permissible “tolerance” levels for the pesticide after several preceding notices and findings indicated that its substantial health risks required revocation of such tolerances. Id. at 818-21 (reviewing regulatory history). The court rejected EPA's claim that the court lacked jurisdiction, noted that it received no pro-government merits arguments, but concluded that the EPA's failure to engage with contrary past findings and science coupled with the statute's protective mandates rendered the action unlawful. Id. at 821-29.

342276 F. Supp. 3d 953 (N.D. Cal. 2017).

${ }^{343}$ Id. passim (discussing state agency’s postponement action).

344 Id. at 963 (quoting 5 U.S.C. § 705 (2012)).

345 Id. at 963-64. The earlier decision was Safety-Kleen Corp. v. EPA, 111 F.3d 963 (D.C. Cir. 1997) (unpublished table decision).

346 No. 17-1155, slip op. (D.C. Cir. Aug. 17, 2018).

347 Becerra, 276 F. Supp. 3d at 964-65.

${ }^{348}$ Id. (citing Nat. Res. Def. Council, Inc. v. EPA, 683 F.2d 752, 762 (3d Cir. 1982), and Consumer Energy Council of Am. v. Fed. Energy Regulatory Comm'n, 673 F.2d 425, 446 (D.C. Cir. 1982), aff'd mem., Process Gas Consumers v. Consumer Energy Council of Am., 463 U.S. 1216 (1983)).

${ }^{349}$ Becerra, 276 F. Supp. 3d at 966 (quoting Consumer Energy Council of Am., 673 F.2d at 446). Air Alliance similarly stated that EPA may not employ "delay tactics" to effectively repeal a final rule while sidestepping the statutorily mandated process for revising or repealing that rule on the merits. Air All. Hous. v. EPA, No. 17-1155, slip op. at 27 (D.C. Cir. Aug. 17, 2018).

${ }^{350}$ California v. U.S. Bureau of Land Mgmt., 277 F. Supp. 3d 1106, 1125 (N.D. Cal. 2017). 
thorough in linking precedent regarding reasoned decisionmaking to analysis of when and how an agency can abandon a previous regulation. "New presidential administrations are entitled to change policy decisions, but to meet the requirements of the APA they must give reasoned explanations for those changes and 'address [the] prior factual findings' underpinning a prior regulatory regime." ${ }^{351}$ Failure to do so is arbitrary and capricious. ${ }^{352}$

Although involving a different sort of regulatory sidestep and hence a different setting for judicial review, the Trump Administration in 2017, through a legal opinion of the Attorney General and then action by the Department of Homeland Security ("DHS"), declared it would abandon the Obama Administration's Deferred Action for Childhood Arrivals ("DACA") program. ${ }^{353}$ Unlike the initial regulations underlying the three earlier decisions just reviewed, the DACA program was not a finalized notice-and-comment regulation, but instead a written, factually explained policy of regulatory forbearance. ${ }^{354}$ The Obama Administration had justified this program with reference to precedents supporting such agency forbearance and prioritization of activities, as well as statutory language providing this latitude. ${ }^{355}$ And, in explaining itself, it discussed the children's plight and ways DACA would be sound policy and comply with the law. ${ }^{356}$

Under the Trump Administration, the 2017 DHS policy change, like other stay and postponement actions that sidestepped the usual policy change process, similarly was rejected for flouting the requirements of the consistency doctrine. ${ }^{357}$ President Trump's DHS relied only on a largely conclusory statement rooted substantially in the view that DACA had violated the Constitution. ${ }^{358}$ Here too, the Trump Administration did not engage with the policy and factual underpinnings of the earlier policy. ${ }^{359}$

${ }^{351}$ Id. at 1123 (alteration in original) (quoting Organized Vill. of Kake v. U.S. Dep't of Agric., 795 F.3d 956, 966 (9th Cir. 2015) (en banc)).

352 Id.

353 Regents of Univ. of Cal. v. U.S. Dep’t of Homeland Sec., 279 F. Supp. 3d 1011, 102526 (N.D. Cal. 2018) (reviewing history of rescinding DACA).

${ }^{354}$ Id. at 1022-24 (discussing DACA Program as announced in June 15, 2012 memo issued by Secretary of Homeland Security Janet Napolitano).

355 Id. (describing Obama Administration's DACA memo legally justifying program).

356 See id. ("Secretary Napolitano found leniency 'especially justified' for the DACAeligible, whom she described as 'productive young people' who 'have already contributed to our country in significant ways.'”).

${ }^{357}$ Id. at 1045 (holding that DHS failed to provide "reasoned explanation” for its change in position).

358 See id. at 1025-26 (reviewing rescission's stated legal grounds).

359 The statutory and constitutional views offered to justified DACA's abandonment constituted a form of statutory abnegation, since the agency's new legal view substantially undercut its earlier claimed authority. See supra notes 102-103 and accompanying text; infra Section IV.F (introducing and analyzing such statutory abnegation justifications for deregulatory actions). 
Judge William Allsup analyzed the legal underpinnings of the DACA program and found that all were legally sound. ${ }^{360}$ Hence, the claim of illegality was rooted in a "flawed legal premise" and, because a court cannot supply a rationale not supplied by the agency, the action had to be rejected. 361 Since the agency had failed to engage with underlying facts and the Obama Administration DHS's stated policy rationales, the Trump Administration regulatory reversal also failed to pass muster under Encino Motorcars and Fox. ${ }^{362}$ The Judge further noted that an agency action that altogether fails to assess overall benefits and costs, or advantages and disadvantages, also runs afoul of the Supreme Court's new default rule in Michigan v. EPA ${ }^{363}$ that agencies must engage in such broader analysis unless it is statutorily precluded. ${ }^{364}$ The agency's failure to engage with the particular facts and administrative record justifying the earlier policy was fatal to the Trump policy. 365

\section{DeREgUlation AND THE CONSTRAints OF AGENCY CONTINGENCY}

Consistency doctrine shapes the contours of when and how agencies can pursue policy change, as well as how courts should police such change. As just shown, these legal constraints are derived from a complex, intertwined, but remarkably consistent and mutually reinforcing body of doctrine. Presidents and agencies usually have latitude to pursue policy change, but that change must follow what is substantively and procedurally required by enabling legislation and the APA. Agencies must fully engage with both their own original findings, data, reasoning, and the arguments and data offered by outside parties. These intertwined sources of doctrine all call for agencies to confront the contingencies

\footnotetext{
360 See Regents of Univ. of Cal., 279 F. Supp. 3d at 1037-43.

${ }^{361}$ Id. at 1042.

362 See id. at 1046 (finding rescission "arbitrary, capricious, and an abuse of discretion under Encino Motorcars").

363135 S. Ct. 2699 (2015).

${ }^{364}$ Id. at 2707; see also Regents of Univ. of Cal., 279 F. Supp. 3d at 1046 (citing Michigan v. EPA, 135 S. Ct. at 2707) (holding that EPA did not adequately consider reliance interests).

365 See Regents of Univ. of Cal., 279 F. Supp. 3d at 1043-45 (applying principles from Encino Motorcars, Fox, and State Farm). This decision shares attributes with the other decisions rejecting deregulatory actions pursued through delay and splintering of the process, but because agency actions rooted in forbearance and enforcement discretion are generally open to later changes in regulatory attitude, the ultimate fate of DACA is far from uncertain. If an appellate court or the Supreme Court disagrees with the judge's "mistake of law" conclusion, the decision could be reversed. Even if the decision is upheld, the Trump Administration DHS on remand could, by offering a correct view of the law, engaging with relevant facts and policy decisions, and offering "good reasons" for its change, possibly reach the same result. See also NAACP v. Trump, 298 F. Supp. 3d 209, 235-44 (D.D.C. 2018) (holding DACA rescission illegal due to failure to provide analysis required by consistency precedents and finding agency rationale inadequate).
} 
that underlay the initial action, provide opportunity for comment, and provide "good reasons" for a policy change.

That these constraints on erratic or unjustified agency policy change derive from a web of interrelated doctrine has both salutary and challenging effects. On the positive side, this web of mutually reinforcing doctrine makes it unlikely that substantial doctrinal change will suddenly occur and allow the sort of erratic, day-to-day abrupt, and unjustified policy shifts that Justice Gorsuch condemned. These rule of law benefits of consistency doctrine in all fields of regulation are unlikely to disappear. To put it more plainly: consistency doctrine is itself deeply rooted, enduring, and likely to remain consistent.

Part III first offers a schematic distilling of the workings of consistency doctrine. Then it turns to an analysis of a few of the major deregulatory policy shifts proposed by the Trump Administration but that have not yet resulted in judicial opinions. This Part concludes with normative discussion of the merits of consistency doctrine before Part IV closes the Article with an assessment of a range of agency settings and the room they leave for political influence.

\section{A. Distilling and Diagramming Consistency Doctrine’s Requirements}

As shown, these many interrelated doctrinal strains governing agency policy change and consistency obligations share a cross-cutting element that is sometimes neglected, especially in recent deregulatory change proposals: an agency seeking to make a policy change always must address the contingencies it originally addressed en route to offering its reasoned elaboration for its initial policy choice. ${ }^{366}$ And it must allow commenters to engage with them as well. Similarly, those and later contingencies - changes in related conditions, the regulatory track record, or reliance interests, for example-will also need to be directly and rationally addressed by the agency proposing change. By recognizing and continuing to enforce this simple but consistent agency obligation - that agencies must forthrightly engage and rationally address past and current contingent factors relevant to the statutorily delegated task-courts substantially reduce the risks of erratic, unjustified action or skirting of science or stakeholders' arguments. Nonetheless, the views and actions reviewed above in Parts I and II indicate either that this body of law is misunderstood or that administrations are sometimes eager to recast or dodge consistency doctrine. Advocates of policy changes and doctrinal adjustment appear to seek greater room for politics and presidents to shape policy changes. Or perhaps change proponents who skip required and challenging antecedent conditions see political gain in granting regulatory relief to their supporters, even if destined for future judicial rejection.

This agency obligation under current doctrine can be captured by two simple diagrams, one setting forth what is required for ordinary "reasoned

${ }^{366}$ See supra Section II.C (discussing cases that require agencies to address underlying contingencies when changing policies). 
decisionmaking” generating an initial policy, and the other analytical obligations of agencies pursuing a later change in policy.

Diagram 1 illustrates what agencies necessarily engage in setting an Initial Regulatory Policy ("IRP”). Agencies will always identify what they view as the most relevant Statutory Language (SL1, SL2, etc.) and linked Policy goals and predictions (P1, P2, etc.), and will need to engage with issues that are central to and often contested about the regulatory choice. These are often the focus of stakeholder Comments (C1, C2, C3) and frequently concern facts, empirical claims about conditions or regulatory impacts, and science. The Policy ("P”) and Comment ("C") factors are often what this Article calls contingencies. However, because an agency's legal analysis often involves judgments melding law and facts, it is in some sense contingent too, but more in the sense that it reflects an agency choice about statutory issues to emphasize. That choice, in turn, will shape the final agency action. And, finally, in the regulatory preamble (and often other accompanying memoranda and appendices), the agency will weave its final choice into a Reasoned Decision ("RD") that will engage with all of these $\mathrm{SL}, \mathrm{P}$, and $\mathrm{C}$ factors or else will risk judicial rejection.

Diagram 1. Initial Regulatory Policy.

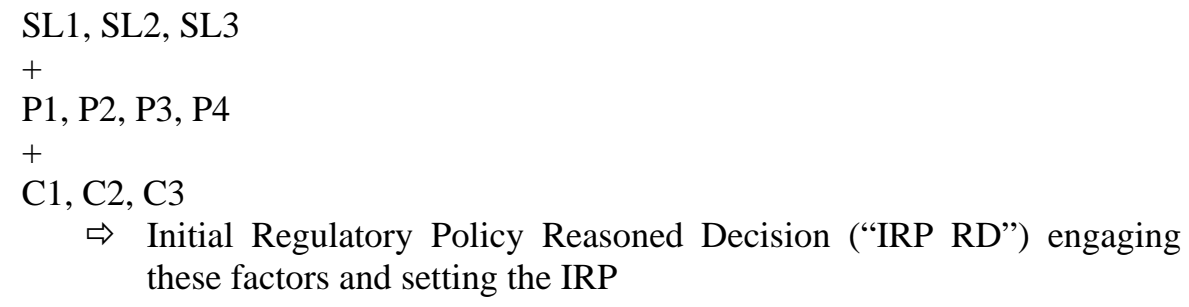
these factors and setting the IRP

Diagram 2 shows how all of the Diagram 1 elements will necessarily become part of the Regulatory Policy Change Proposal ("RPCP”), plus other elements will be added. Those supporting the IRP will surely draw on all explanations provided in the IRP, including the Reasoned Decision itself, while those advocating change will argue against those factors, in comments supplying new facts and arguments, and also questioning the wisdom of the RD justifying the IRP. The RD and IRP will themselves become new mandatory analysis elements because they will be contested, as will any intervening change or IRP impacts. The new agency leadership proposing policy change may focus on new language and likely some new science, data, or empirical claims about the world, even though it will need to address the old justifications.

Hence, consistency doctrine's web of law will require the agency to address the following in seeking to make a policy change. 
Diagram 2. Regulatory Policy Change Proposal.

SL1, SL2, SL3 plus new SL4

$+$

P1, P2, P3 plus new P4, P5

$+$

C1, C2, C3, C4 plus new developments, facts, science, regulatory experience, and reliance interests $\mathrm{C} 5$, C6

+ IRP RD and IRP

$\Rightarrow$ RD for Policy Change

As illustrated by these simple diagrams, the basics of reasoned decisionmaking and consistency doctrine mean that policy changes will require more analysis and justification by an agency. Note that this does not mean that policy change triggers a different standard of review; instead, an agency proposing a policy shift must engage in more explanation to provide "good reasons" for the change and explain why the choice is reasonable. ${ }^{367}$

\section{B. Assessing Major Deregulatory Proposals by the Trump Administration}

The Trump Administration's many deregulatory actions constitute the most concerted deregulatory push since the State Farm decision and linked deregulatory efforts of the Reagan Administration. ${ }^{368}$ Where agencies and lawyers have addressed policy change law, they have usually relied on near cookie-cutter citations to State Farm and Fox in deregulatory actions that provide a rationale, often also including some references to Chevron. ${ }^{369}$

367 This logic illuminates the "more is needed" language in State Farm, Fox, and Encino Motorcars. See supra Section II.C. (analyzing these cases).

368 See President Donald J. Trump Is Delivering on Deregulation, THE White House (Dec. 14, 2017), https://www.whitehouse.gov/briefings-statements/president-donald-j-trump -delivering-deregulation/ [https://perma.cc/D9RU-ZLYB] (stating deregulatory goals and tallying claimed deregulatory progress).

369 As of January 2018, a Westlaw search limited to the Trump Administration Federal Register notices finds twenty policy change proposals citing to some or all of these cases. The Trump Administration has claimed a vast number of deregulatory actions. See id. But early analysis indicates some are quite minor, some are preliminary, and many are merely finalizing policy shifts that had started under earlier administrations. See Press Briefing by Office of Information and Regulatory Affairs Administrator Neomi Rao on the Unified Agenda of Regulatory and Deregulatory Actions, THE White House (Dec. 14, 2017), https://www.whitehouse.gov/briefings-statements/press-briefing-office-informationregulatory-affairs-administrator-neomi-rao-unified-agenda-regulatory-deregulatory-actions/ [https://perma.cc/M78V-AQMZ] (summarizing 2017 deregulatory actions, anticipated 2018 actions, and providing numerical tallies of such action); The Trump Assault on Our Safeguards, CENTER FOR PROGRESSIVE REFORM, http://www.progressivereform.org/ 
Administration advocates describe these cases as allowing policy change due to a change in administrations and presidential priorities, but so far provide little effort to satisfy the other legal requirements set forth in these cases. ${ }^{370}$ They are correct that change is possible and is not subject to some special heightened, skeptical standard of review. ${ }^{371}$ However, several recent major regulatory policy change actions fail to engage with most of the contingencies-especially "underlying facts" and past agency reasoning - that the same agencies in earlier actions identified to justify their initial actions. Although, as reviewed in Section II.H, a raft of rapid deregulatory actions that involved regulatory shortcuts and avoidance of usual APA process resulted in judicial rejections, several of the highest visibility and high stakes actions are, as of this Article's publication, either in the regulatory pipeline or not yet reviewed. This Part assesses their conformity with consistency doctrine's requirements.

As introduced earlier, the two most significant environmental policy reversal initiatives seek to abandon the Clean Water Rule, a rule defining what sorts of waters are jurisdictional "Waters of the United States," and the Clean Power Plan, a rule regulating existing power plants to restrict their emissions of GHGs. ${ }^{372}$ Both were initially pursued with little effort to satisfy consistency doctrine's requirements for agencies making a policy change.

For example, the one finalized action of these various proposals is the EPA and the Corps adding a new "applicability date" that would delay any application of the finalized 2015 Clean Water Rule. Yet despite litigation and regulatory claims of the Clean Water Rule's opponents that it would impose massive hardship, the agencies in this final action claimed that a return to the pre-2015 landscape would result in no costs. ${ }^{373}$ They identified no changes in environmental conditions that would result from the 2015 rule going into effect, versus its suspension for two years. In this action, they nowhere even mentioned the implications of the Connectivity Report the EPA had earlier created that summarized categories of waters and their functions. ${ }^{374}$ Hence, in this one

trumpassault.cfm [https://perma.cc/KF8X-6VMS] (last visited Sept. 10, 2018) (analyzing President Trump's use of executory power for regulatory actions).

370 See supra Section I.E (discussing Trump Administration's deregulatory proposals and frequent lack of reasoning or engagement with facts in policy changes sought).

${ }^{371}$ Fox and State Farm make explicit that the usual standard of review applies, but both also explain why policy change will usually require greater explanation than creation of an initial policy. See supra Section II.C (discussing these cases).

372 See supra Sections I.E, II.C (introducing and analyzing legality of Clean Water Rule and Clean Power Plan change proposals).

373 Definition of "Waters of the United States"-Addition of an Applicability Date to 2015 Clean Water Rule, 82 Fed. Reg. 55,542, 55,544 (proposed Nov. 22, 2017) (stating that there are "no economic costs or benefits associated with this action").

${ }^{374}$ In the 2018 Supplemental Notice, the EPA and the Corps did-for the first time in the sequence of actions linked to the Clean Water Rule's repeal or change in the effective or "applicability" date-refer to and raise some questions about the Connectivity Report and the agencies' reliance on it. See Definition of “Waters of the United States”-Recodification of 
finalized action, the agencies omitted any discussion or concession of real-world impacts of the two legal choices on the table: application of the Clean Water Rule or its suspension and possible eventual revocation. . $^{375}$

Clean Power Plan change proposals by the Trump Administration have also been splintered, with most providing little or no discussion of clean energy trends or impacts of abandonment. ${ }^{376}$ The EPA's initial explanation in 2017 for preferring its "inside the fenceline" approach nowhere provides textual and factbased analysis of how this interpretation, in the setting of power plants integrated into the grid, satisfies the statutory requirement that pollution limitations be set based on the "best system of emissions reduction ... adequately demonstrated." ${ }^{377}$ Hence, with this rule change too, the earliest documents indicate a declination to engage with salient contingencies and, by limiting comment, fracturing the change proposals, and offering no replacement, squelch commenters from raising them. ${ }^{378}$ Late 2018 agency proposals regarding both "waters" jurisdiction and power plant GHG regulation, which followed a string of judicial losses for these and other agencies pursuing deregulatory impacts through shortcuts, provided more substantial justifications and at least passing engagement with earlier science, findings, and impacts. ${ }^{379}$

Most of these splintered proposals in their texts failed to address the fundamental questions and tasks called for by consistency doctrine: Are there "good reasons" for the change? What is the agency's current view of "underlying

Preexisting Rule, Supplemental Notice of Proposed Rulemaking, 83 Fed. Reg. 32,227, 32,241-42 (July 12, 2018).

375 As this Article goes to print, a federal district court had rejected the legal sufficiency of the Applicability Date rule (which it called "the Suspension Rule"), focusing on the consistency doctrine infirmities addressed in the text and connecting the action's legal inadequacies to other "hastily" crafted deregulatory actions. S.C. Coastal Conversation League v. Pruitt, No. 2:18-cv-00330, slip op. at 6-18 (D.S.C. Aug. 16, 2018). That court did not address the merits of Clean Water Rule itself or latitude for a revised rule. See id.

376 The EPA under the Trump Administration appears to have removed from its own active public databases studies and analytical memoranda that accompanied and explained the final CPP.

377 See Clean Air Act $\S 111(a), 42$ U.S.C. § 7411(a) (2012) (providing definitional language that ties into § 111(d)).

378 Several recent decisions on other regulatory policy shifts in the form of postponements, stays, or summary policy shifts without notice-and-comment rulemaking opportunities reject similar sidestepping of agency obligations to directly confront and explain a policy shift. See supra Section II.H (discussing these decisions).

379 See Emission Guidelines for Greenhouse Gas Emissions from Existing Electric Utility Generating Units; Revisions to Emissions Guidelines Implementing Regulations; Revisions to New Source Review Program, 83 Fed. Reg. 44,746, 44,746 (proposed Aug. 31, 2018) (proposing to replace CPP with unit-based focus and technological improvements, offering more substantial analysis and justification, and imposing no comment limitations); Definition of "Waters of the United States"-Recodification of Preexisting Rule, Supplemental Notice of Proposed Rulemaking, 83 Fed. Reg. at 32,231-50 (engaging more fully merits of Clean Water Rule and its proposed repeal). 
facts" that justified the initial action? Are there any changes in conditions or reliance interests? Has the agency made sure there are no "unexplained inconsistencies" between the new and old policy?

In fact, by trying to effect change without required legal and factual engagement, the string of Trump Administration regulatory actions seeking to undo these two major environmental rules present circumstances similar to those underlying the many 2017 and 2018 judicial rejections of agency stays and postponements that had in effect sought to render finalized regulations ineffective. ${ }^{380}$ The EPA has sought to accelerate regulatory change by abandoning the old rules, but without required engagement with the contingencies that justified the earlier actions and where such science or facts might be difficult to overcome. ${ }^{381}$ These larger-impact policy shifts hence also seem vulnerable to judicial rejection. 382 Other agencies' deregulatory actions have also triggered criticism for agency dodging of studies that contradict their claimed benefits. ${ }^{383}$ However, one agency, the independent Federal Energy Regulatory Commission ("FERC"), unanimously declined a request by the Department of Energy to change policies to support the coal industry, finding it legally and factually without merit. ${ }^{384}$

In later final agency rules and related court briefing, agencies and their lawyers may engage more fully with the contingencies addressed earlier. ${ }^{385}$ They

380 See supra Section I.E.5 (presenting these actions); supra Section II.H (discussing these judicial rejections of Trump agency deregulatory efforts).

381 In particular, both initial actions were accompanied by massive empirical studies that would be hard to controvert. See supra notes 113-50 and accompanying text (discussing Clean Water Rule and Clean Power Plan rollbacks and lack of justification by Trump administration).

382 See supra Sections II.B, II.C (reviewing two-step deregulatory efforts by Trump Administration and earlier administrations' unsuccessful efforts to shift policy without full engagement with relevant facts and past reasoning).

383 See, e.g., Ben Penn, Labor Dept. Ditches Data Showing Bosses Could Skim Waiters' Tips, Bloomberg L. Daily LaB. ReP. (Feb. 1, 2018, 6:01 AM), https://bnanews.bna.com/ daily-labor-report/labor-dept-ditches-data-showing-bosses-could-skim-waiters-tips [https://perma.cc/K8L9-PE69] (reporting that Labor Department "scrubbed an unfavorable internal analysis" showing that change to tip retention regulations would result in employees "los[ing] out on billions ... in gratuities"). There was an underlying regulatory proposal. See generally Tip Regulations Under the Fair Labor Standards Act (“FLSA”), 82 Fed. Reg. 57,395 (Dec. 5, 2017). The proposal traces the earlier regulation's history but provides little detail on impacts of the old rule or under the new rule. Id. at 57,396-401 (reviewing history of proposal and stating that department "lacks data to quantify possible reallocations of tips" and hence presents "primarily qualitative approach”). This regulatory skirmish was ultimately resolved with a legislative deal.

384 Order Terminating Rulemaking Proceeding, Initiating New Proceeding, and Establishing Additional Procedures, 162 FERC \ 61,012 (Jan. 8, 2018) (ordering federal agencies to submit additional information supporting proposed rulemaking).

385 For example, the FCC's Restoring Internet Freedom action is near final and more carefully addresses legal requirements regarding policy change. See supra notes 108-111 and 
should learn from the judicial rejections, as perhaps reflected in the EPA's more substantial proposals published in late 2018. However, when an agency splinters its actions, sidesteps or cherry-picks relevant studies, and constrains comment, the agency has likely already doomed the actions to judicial rejection due to an agency's obligations at the notice stage to disclose its planned action and rationale. 386

\section{Consistency Doctrine's Policy Merits}

The question remains, of course, whether this body of consistency doctrine and the agency obligation to address policy contingencies add up to a sound policy result. This Article argues that the very consistency of the consistency doctrine over many years, especially its many mutually reinforcing elements, reflects its soundness and deep rule of law roots. It also reflects the compromises and balancing acts that pervade administrative law. Congress can set policies leaving room for policy adjustments by agencies, and presidents can in an array of ways seek to nudge agencies in a particular direction. But congressional delegations regarding chosen actors, procedures, and criteria for action must be respected by presidents, agencies, and reviewing courts, regardless of whether the agency is setting an initial policy or seeking change. Current doctrine balances stability with responsiveness, and provides comfort to those worried about either overregulation or unwarranted deregulation.

Further, by prohibiting erratic or abrupt policy shifts and requiring agency engagement with facts, this body of doctrine checks sloppy, corrupt, or opportunistic regulatory capitulation to powerful stakeholders. ${ }^{387}$ Congressional goals and means set forth in statutes are protected and enforced by consistency doctrine. It is rooted in respect for legislative supremacy. By compelling agencies to engage with underlying facts, science, and points of contestation underlying a choice (be it an initial choice or a later change proposal), this body of law buttresses the quasi-democratic virtues of stakeholder voice, agency explanation obligations, and related accountability and rule of law virtues. ${ }^{388}$ If an agency cannot confront data or science and justify a regulatory change under

accompanying text (discussing FCC's abandonment of Net Neutrality regulation promulgated in 2015 and noting agency's proffered reasoning for policy change).

386 See supra Section II.H (describing recent judicial rejections of such agency actions); supra note 258 and accompanying text (discussing "logical outgrowth" obligations and policy change).

387 See Gersen \& Vermeule, supra note 70, at 1396 (stating that agency obligations to engage comments and justify choices serves to "flush out illicit motivations"); Short, supra note 17, at 1821-23 (exploring how rational public explanation serves to discipline agencies); Stiglitz, supra note 164, at 637-40 (analyzing how agency obligations to provide process transparency, explain choices, and surmount judicial review address public distrust and concerns about comparatively less open legislative process).

${ }^{388}$ Cf. Bressman, supra note 69, at 764-66 (noting that Supreme Court values political accountability in form of electoral accountability, quasi-democratic participatory opportunities, and agency responsiveness to input and criticisms). 
relevant law, then the proposed change should be abandoned. By requiring agencies to engage with "circumstances" and the "record," and provide a "reasoned analysis for the change,"389 consistency doctrine largely prevents an agency from ignoring or sweeping under the rug a salient and potent criticism or contrary study. ${ }^{390}$ And when an agency makes a policy change with full and adequate explanation, then all facets of political accountability are reinforced. The agency is subject to political accountability when it respects legislativelyset priorities, engages with relevant data, science and stakeholder comments, and takes political responsibility for its own regulatory choices. ${ }^{391}$

Similarly, when Fox and Encino Motorcars state that agencies must offer "good reasons" for a change, and must address "facts and circumstances that underlay or were engendered by the prior policy" and address "findings that contradict" the prior policy, the Court also is precluding agencies hoping to dodge reality. ${ }^{392}$ And in stating that "unexplained inconsistency" is grounds for rejection, the Encino Motorcars Court (drawing on the Brand $X$ case's language and logic) is necessarily stating that the agency proposing a policy change must engage with the previous action and its rationales and explain the later change. 393

Could agencies and departments substantially revise the many rules that during 2017 and 2018 were subject to delay proposals, proposed for rescission, or under reconsideration? Probably so. Neither agencies nor presidents are obligated to stick with earlier administrations' regulatory choices if they lean in a different direction. But they must satisfy other prerequisites for a change, especially compliance with statutory criteria and procedures. Even if the President weighs in, the agencies would need to fully confront the earlier rationales, science, disputes, and allow full ventilation of comments, usually in a notice-and-comment process. Some degree of change is almost always possible because statutes, regulatory design choices, and underlying science or data rarely point only to one acceptable action.

But as emphasized in these cases, especially in Massachusetts v. EPA, agencies need to ground their policy choices or changes in what the statutes set forth as criteria for action. ${ }^{394}$ By requiring "fidelity" to underlying statutory requirements as well as open and reasoned deliberation and justification,

389 Motor Vehicle Mfrs. Ass'n of U.S., Inc. v. State Farm Mut. Auto. Ins. Co., 463 U.S. 29, 42 (1983).

390 See supra Section II.C (discussing relevant case law regarding consistency doctrine).

391 Judge Bates stated in NAACP v. Trump, "an official cannot claim that the law ties her hands while at the same time denying the courts' power to unbind her. She may escape political accountability or judicial review, but not both.” NAACP v. Trump, 298 F. Supp. 3d 209, 249 (D.D.C. 2018).

392 Encino Motorcars, LLC v. Navarro, 136 S. Ct. 2117, 2126 (2016) (quoting FCC v. Fox Television Stations, Inc., 556 U.S. 502, 515-16 (2009)); Fox, 556 U.S. at 515.

393 Encino Motorcars, 136 S. Ct. at 2126 (quoting Nat'l Cable \& Telecomms. Ass'n. v. Brand X Internet Servs., 545 U.S. 967, 981 (2005)).

394 See Massachusetts v. EPA, 549 U.S. 497, 533 (2007); supra notes 8 and accompanying text (discussing requirements set forth in Massachusetts $v$. EPA). 
consistency doctrine reinforces the three types of political accountability that underpin regulatory legitimacy: (1) legislative supremacy (in Congress choosing the regulator and devising criteria and procedures for the agency's work); (2) responsiveness to presidential leadership; and (3) an open, transparent process and reasoning that constitutes a form of responsive and quasi-democratic action. 395

Hence, to satisfy the law and judicial statements about policy change, agencies must avoid gamesmanship and show frank and accountable engagement. ${ }^{396}$ They must engage in reasoned decisionmaking that frankly addresses both supportive and contrary evidence, shaped as always by what statutes allow. Political predilections of a president and his leadership can shape choices at the margins, and often will have major latitude to shape general agency directions and priorities. ${ }^{397}$ No cases or laws, however, allow an agency to short-circuit the regulatory process or dodge salient contingencies. In requiring agencies and presidents to make policy with integrity and respect for what the law allows and what the data and science indicate, and provide "good reasons" for a change, this body of law creates sound incentives. If properly understood and followed, this body of law should address fears of critics focused on overregulation and arbitrariness, as well as those focused on political overreach or unjustified deregulation.

\section{Deliberative INTEgrity AND TETHERING’s DEgREeS}

Despite the clear collective import of consistency doctrine's multiple facets, a remaining task is to identify policy change contexts and the degree of tethering constraints faced by agencies, political appointee leadership, and presidents. The degree of tethering links to the obligation of agencies to pursue policy change in ways reflecting what this Part will refer to as "deliberative integrity." These elements of deliberative integrity are drawn from the cases creating consistency doctrine and the linked enduring requirements of reasoned decisionmaking. ${ }^{398}$ Deliberative integrity in the setting of a policy change involves three central elements: (1) the action must be congruent with the underlying statute's substantive choices and mandated procedures; (2) it must fairly address the factual underpinnings and reasoning behind the earlier policy action, and justify

\footnotetext{
395 See Garland, supra note 9, at 553-56 (describing State Farm's requirements as designed to ensure agency "fidelity" in sense of prioritizing legislative policy choices set forth in statutes over mere political responsiveness to presidential or agency views); Stiglitz, supra note 164, at 649-72 (exploring how trust-creating legitimacy in agency process and subsequent judicial review can explain legislative reliance on agencies).

396 For a similar emphasis on integrity, see Kozel \& Pojanowski, supra note 7, at 148-49 which emphasizes the need for agency "sincerity," "fidelity," and "candid reason-giving."

397 See supra note 17 and accompanying text (citing Watts, Seidenfeld, and Short regarding balance of politics and rationality in shaping agency actions).

398 See supra Part II (discussing requirements of consistency doctrine and of "reasoned decisionmaking”).
} 
the new action with "good reasons"; and (3) it must provide meaningful opportunities for engagement of all affected by the earlier and proposed new policy. The following Sections start with the least constrained settings and move to contexts where agencies and presidents face the greatest hurdles in changing policy.

\section{A. The Presidential Nudge and Enforcement Prioritization}

Scholars and doctrine share the view that agencies can appropriately be subject to presidential nudging and politicized input in selecting priorities for action, especially when setting a regulatory agenda. ${ }^{399}$ Few laws set priorities among the many assigned agency tasks. Even rarer are laws that instruct agencies how to juggle tasks delegated under multiple laws. Because most agencies have hundreds of finalized regulations on the books, typically those agencies and the President face no statutory constraint in deciding which are most in need of reexamination.

Justice Kagan (then-Professor Kagan) noted and applauded presidential involvement in rulemaking rollouts and agency initiatives. ${ }^{400}$ Similarly, presidential agenda-setting and oversight, nowadays usually through OIRA, is also generally unproblematic. On the other hand, where a statute sets a deadline, an agency cannot disregard it due to an administration's anti-regulatory leanings or cost-benefit analysis delays or hurdles. ${ }^{401}$

A tougher question concerns prioritization of cost-benefit analysis in driving regulatory revisions. ${ }^{402}$ For almost forty years, presidents of both parties have ordered agencies to weigh costs and benefits of major rulemakings and subjected rulemakings to OIRA's oversight. ${ }^{403}$ Such considerations and oversight are not necessarily or blatantly illegal, but their legality is critically reliant on their stated and actually applied subservience to statutory requirements. ${ }^{404}$ Whether

399 See supra note 3 and accompanying text (citing to and discussing scholarship regarding extent of presidential authority over agencies).

400 See Kagan, supra note 3, at 2333 (characterizing President Clinton's high degree of involvement in rulemaking process as "more desirable").

401 See Envtl. Def. Fund v. Gorsuch, 713 F.2d 802, 817-18 (D.C. Cir. 1983) (enforcing deadlines and invalidating suspension of regulation for lack of required preceding process); Envtl. Def. Fund v. Thomas, 627 F. Supp. 566, 571-72 (D.D.C. 1986) (stating agency cannot miss statutory deadline due to Office of Management and Budget review); Jacob E. Gersen \& Anne Joseph O’Connell, Deadlines in Administrative Law, 156 U. PA. L. REV. 923, 966 (2008) (analyzing use and constitutionality of deadlines in administrative law statutes).

402 President Trump's two-for-one deregulatory order raises this issue. See supra notes 9196 and accompanying text (discussing two-for-one deregulatory order).

403 Lisa Heinzerling, Inside EPA: A Former Insider's Reflections on the Relationship Between the Obama EPA and the Obama White House, 31 PACE EnVTL. L. REV. 325, 327 (2014) (discussing agencies' use of cost-benefit analysis throughout presidential administrations since Reagan).

404 See Exec. Order No. 12,866, 58 Fed. Reg. 51,735 (Oct. 4, 1993) (stating that order’s requirements do not apply if contrary to other law). 
OIRA, agencies, and presidents respect this primacy of statutory choices is far from clear. ${ }^{405}$ Presidents can indicate their personal priority of cost-benefit justified regulations and minimization of regulatory costs, and easily provide input on regulatory actions to undertake. In addition, Michigan v. EPA has created a default rule that broad delegations to agencies should be read to leave room for balanced assessments of both regulatory benefits and costs. It provides agency leaders and presidents with enhanced latitude to nudge agencies to consider such effects. ${ }^{406}$ Within each action, however, such orders can only be interpreted as requests due to the stated primacy of statutory criteria and procedures. ${ }^{407}$ Through appointments and perhaps also appropriations requests, the President can legitimately stack an agency with personnel sharing such leanings. Similarly, a President's request for agencies to report on their work is a constitutionally rooted power, as Professor Strauss observes. ${ }^{408}$

But to avoid questionable assertions of power, a President and agency political appointees must still respect the congressional choices of the delegate for assigned tasks and the criteria for those tasks. ${ }^{409}$ They must allow action based on that delegate's application of those criteria, through congressionally devised procedures, applying the contingent factors and in light of contingent facts made relevant by law. ${ }^{410}$ The more the statutory language sets forth specifics about what is required, the less agency leadership or the President (perhaps through OIRA) can seek to change the agency action. ${ }^{411}$

One common setting involving generally permissible political considerations is agency decisions to accelerate or delay discretionary regulatory actions that are underway, but not yet finalized or in effect. The APA, in Section 705, allows agencies to take such action before rules take effect. ${ }^{412}$ And many agencies start, but never finish, regulatory proceedings. It is, of course, quite different if a

\footnotetext{
405 For analysis questioning the legality of OIRA's oversight as actually applied, see Heinzerling, supra note 403.

406 See Michigan v. EPA, 135 S. Ct. 2699, 2707-11 (2015).

407 But see Heinzerling, supra note 403, at 325-27 (questioning legality of OIRA's actual work).

408 See Strauss, supra note 3, at 977-79 (discussing amount of discretion delegated to President regarding administrative state).

409 See supra Sections I.D, II.A (discussing this issue).

410 See supra note 8 and accompanying text (discussing Massachusetts v. EPA); supra Section II.A (discussing enabling act constraints on agencies).

411 Executive Order 12,866 even if followed as written, adds a decisionmaker not empowered by Congress in the enabling act, changes the criteria for decision (or at least adds a final additional cost-benefit filter), and changes congressionally set process. Exec. Order No. 12,866, 58 Fed. Reg. 51,735 (Oct. 4, 1993). Consequently, a strong argument exists that OIRA's work is inherently illegal whenever it goes beyond calls for analysis.

412 Administrative Procedure Act § 705, 5 U.S.C. § 705 (2012). For discussion of agencies relying on this section and judicial responses, see Section II.H.
} 
statute sets deadlines for required actions-courts will enforce such mandates. ${ }^{413}$ One caveat remains: agencies that generate data, studies, and reasoning, even if resulting in an abandoned action, could later need to engage with those materials if taking a related action where they remain relevant. ${ }^{414}$

\section{B. Turf Conflicts}

Agencies and presidents can broadly engage in politicized direction when agencies come into conflict over particular actions, or perhaps conflict over who has primacy over a regulatory turf. Such settings of uncertain and potential overlapping turf are quite common and can create problems of conflicting mandates and inefficient duplication of work ${ }^{415}$. Regulatory obligations can accumulate over time. ${ }^{416}$ Such overlaps can also result in "regulatory commons" dynamics, where stakeholders and potential regulators fail to act either out of fear of waste, free riding incentives, or because the magnitude of need for action may not be apparent to any single actor. ${ }^{417}$ Statutes may create rules of decision for how to handle conflicts. But if such regulatory overlaps and collisions are not anticipated by the statutes, then White House leadership provides one of the few means to sort things out. No statutory language would guide and hence constrain the president or affected agencies in resolving turf conflicts. And, as with agenda-setting and determination of priorities, this reality means turf conflicts are often legitimately subject to a degree of politicized presidential and agency problem solving that is subject to few constraints, provided that each agency's congressionally delegated role is respected.

\section{Broad New Deal Delegations}

Many agencies, often in the form of commissions dating back to the New Deal, have long acted under statutes with remarkably broad delegations. Such laws often do little more than empower an agency with broad regulatory goals, such as to act in the public interest, to protect the integrity of markets, to police

413 See, e.g., Envtl. Def. Fund v. Gorsuch, 713 F.2d 802, 814-18 (D.C. Cir. 1983) (discussing and enforcing deadlines, and rejecting claimed postponements that had effect of undoing valid regulations but without required process).

414 See, e.g., Pub. Citizen Health Research Grp. v. Tyson, 796 F.2d 1479, 1505-07 (D.C. Cir. 1986) (requiring agency engagement with earlier studies in changed agency action).

415 See Bijal Shah, Congress's Agency Coordination, 103 Minn. L. REv. 67, 69 (forthcoming 2018) (identifying many settings of overlap but also congressional awareness and rules for resolving conflict).

416 See generally J.B. Ruhl \& James Salzman, Mozart and the Red Queen: The Problem of Regulatory Accretion in the Administrative State, 91 GEO. L.J. 757 (2003) (discussing how regulations accrete in modern administrative state).

417 See Buzbee, supra note 72, at 5 (explaining that regulators often leave social ills unaddressed due to uncertain regulatory domains and resulting political and economic incentives). 
unfair marketing, or to provide a safe workplace. ${ }^{418}$ At first blush, one might think that broad delegations would automatically imply broad latitude for politicized redirection of policy. However, agencies pursuing policy change are constrained both by the tasks assigned by legislation and by the line of preceding policies and actions taken by an agency, as well as possibly relevant judicial precedents. Such agencies often engage in technical and context-sensitive policy creation about, for example, what workplace actions are veiled threats and hence unfair labor practices, or which market actions are the result of legitimate aggressive competition, or reflect illegal, unfair, or anticompetitive behavior. ${ }^{419}$

Policy devised through a sequence of adjudicatory actions and resulting opinions, usually with some additional guidance documents and perhaps linked notice-and-comment rulemakings, can create a complex web of policy with diverse policy rationale contingencies. ${ }^{420}$ As a result, such an agency pursuing a policy change may face little constraint from broad statutory language, but that does not mean lack of tethering. Constraining contingencies may be many and hard to overcome. Even if each preceding policy step is modest and clear, their sequential accumulation and their on-the-ground effects can create a formidable hurdle to any large-scale abrupt policy change. ${ }^{421}$ And due to the development of reliance interests, stakeholders will rarely sit out a possible regulatory upheaval. As a result, the agency pursuing change will be forced to engage with its own accumulated regulatory law, empirical data, and stakeholders' advocacy about the implications of retaining or changing a policy.

\section{Science-Based Judgments and the "Best"}

Since the late 1960s, many statutes have, at great length and detail, regulated risks to safety, health, and the environment. ${ }^{422}$ The specificity in these laws' criteria and procedures constrain agencies and presidents who might otherwise weigh politics heavily in making a regulatory choice. In contrast to broad New

418 Cf. Whitman v. Am. Trucking Ass’n, 531 U.S. 457, 474-75 (2001) (rejecting delegation doctrine challenge while citing to cases upholding constitutionality of broad delegations). See generally Magill, supra note 168, at 1400-02 (reviewing broad delegation language and its implications for agency choice); Solove \& Hartzog, supra note 11 (reviewing FTC policy development under broad language).

419 See, e.g., Shaw’s Supermarkets, Inc. v. NLRB, 884 F.2d. 34, 37-41 (1st Cir. 1989) (discussing NLRB's policy evolution regarding "bargaining from scratch" threats but requiring agency to "follow[] or consciously change" policy with explanation). See generally Solove \& Hartzog, supra note 11 (discussing FTC’s policy evolution).

${ }^{420}$ See generally, e.g., Solove \& Hartzog, supra note 11 (analyzing such policy development).

421 See generally Ruhl \& Salzman, supra note 416 (explaining dynamics leading to regulatory accretion).

422 See Thomas O. McGarity, Freedom to Harm: The LAsting Legacy of THE LAisSEZ FAIRE Revival 18-32 (Yale Univ. Press 2013) (describing establishment of modern administrative state's protective regimes in book tracing emergence of opposing "laissez faire revival”). 
Deal delegations, these modern risk regulation laws often include micromanaging instructions about the assigned task, triggers to justify action, and criteria for the agency to apply in regulating. ${ }^{423}$ Moreover, many such laws, especially in the environmental area, require agencies to set performance standards benchmarked against what the "best" in some category can achieve, often to meet some health or endangerment-based target. ${ }^{424}$ Because such standard setting is data-based and often fiercely contested, policy revision efforts are laden with every imaginable constraint. The actor is usually specified, the criteria for action chosen by Congress, and data about the risk intensively gathered and distilled to meet the inevitable judicial challenge to any high-stakes economic regulation. Such legal criteria are unlike laws that call for broad value judgments, such as the FCC's changing views of obscenity on television in Fox, or laws calling for agencies to juggle many potentially clashing mandates. ${ }^{425}$

In the setting of these science and data-based "best" determinations, nothing is likely to present clean questions of law interpretation untethered to a raft of contingencies and stated agency rationales. Agencies draw on their knowledge of the regulatory regime's interconnections, affected stakeholders' interests, relevant science and data, and the results of different choices. ${ }^{426}$ Little is left to political discretion in its broadest sense, or to mere agency analysis of words.

Deliberative integrity in such settings will involve respect for congressional choices of delegate, procedures for action, compliance with often highly reticulated criteria for action, and grappling with contingent data. ${ }^{427}$ Agencies cannot, out of nowhere, put procedures and substantive choices all back in play, especially if at the direction of the President or a political appointee, without raising warning flags for later reviewing courts. ${ }^{428}$ Of course, some change at the margins will seldom present a problem. But pre-judging, political pressures, dodging of comment on a de facto regulatory abandonment, or ignoring of a body of science or data previously viewed as determinative, will all raise

423 See, e.g., Michael Herz, Judicial Textualism Meets Congressional Micromanagement: A Potential Collision in Clean Air Act Interpretation, 16 HARV. ENVTL. L. REV. 175, 175-82 (1992) (analyzing increasing statutory specificity).

424 See, e.g., Clean Air Act of $1963 \S \S$ 109, 111, 112, 42 U.S.C. §§ 7409, 7411, 7412 (2012) (setting up such "best" achievable benchmarked regulation for different sorts of pollution, sources, and contexts).

425 See FCC v. Fox Television Stations, Inc., 556 U.S. 502, 505-10 (2009) (reviewing history of policy and agency action); Antonin Scalia, The Role of the Judiciary in Deregulation, 55 ANTITRUST L.J. 191, 196 (1986) (discussing prevalence of laws requiring agencies to "weigh ... competing policies" and latitude they provide for regulatory changes).

${ }^{426}$ See supra Section I.A (describing Congress' reliance on agencies to develop regulatory policy based on their respective expertise).

427 See Stack, supra note 3, at 284 (arguing courts and presidents should respect different congressional choices about delegation to President versus to an agency); Strauss, supra note 3 , at 968 .

428 Judulang v. Holder, 565 U.S. 42, 56-57 (2011); see also supra notes 252-256 and accompanying text (discussing Judulang). 
concerns about lack of deliberative integrity and reasoned decisionmaking, thereby increasing the odds of judicial rejection. ${ }^{429}$

For this reason, the initial high-stakes efforts by the Trump Administration to abandon environmental regulations have foundered and are likely to continue to do so. Most of these actions did not directly engage or engage in depth in the merits of earlier policy choices. ${ }^{430}$ Deliberative comment was constrained. ${ }^{431}$ Agencies often avoided comment on the fundamental issue of whether an agency can or should abandon an earlier regulatory choice. ${ }^{432}$ Or the agency proposed a fundamental new limiting construction of statutory language, yet without explaining why this new read was better or even required. ${ }^{433}$

\section{E. Presidential Adjudicatory Interventions}

Not all presidential nudges or agency weighing of politicized considerations are unproblematic. Most policy shifts discussed in this Article involve policies developed through rulemakings or over a series of regulatory actions. These are settings where some degree of presidential or political appointee involvement is typical. However, presidential interventions can occur in adjudicatory settings. ${ }^{434}$ As mentioned above, President Trump issued a legal memorandum that indicated the outcome he sought in a highly-publicized battle over a pipeline threatening Native American lands and waters. ${ }^{435}$ The Army Corps subsequently complied, even referring to the President's memorandum as constituting a presidential "direction," but the Army Corps' minimal regulatory analysis and explanation were later found lacking in a court. ${ }^{436}$

${ }^{429}$ See, e.g., Sierra Club v. EPA, 884 F.3d 1185, 1195-97 (D.C. Cir. 2018) (rejecting EPA changes to rule regarding industrial boiler pollution due to record inadequacy, especially unexplained inconsistencies in characterization of reliability of data in earlier and changed rule explanations).

${ }^{430}$ See supra Sections I.E, II.H, III.B (describing Trump Administration's claims of broad agency authority to reverse course with little constraint, courts' treatment of such claims, and analyzing constraints on agency policy change).

431 See supra Sections I.E, II.H, III.B (describing Trump Administration's change power claims); see e.g., supra notes 100-101 and accompanying text (discussing splintering of deregulatory moves and agency instructions for commenters to limit focus, and judicial rejection of such limitations).

432 See supra Sections I.E, II.H, III.B (presenting and analyzing Trump Administration's policy change authority claims and how many such change efforts have not included discussion of relative merits of old policy to be abandoned or new replacement policies).

433 See supra Sections I.E, II.H, III.B (presenting many such actions); supra notes 102-111 (presenting such authority-limiting actions, including many agency statutory abnegations that have often included only summary explanation, as well as cases rejecting poorly justified changes); infra Section IV.F (explaining unlikelihood of success of such proposals).

434 See Percival, supra note 3, at 2534.

435 See supra notes 153-157 and accompanying text.

436 See supra notes 153-157 and accompanying text. 
This disputed Dakota Access Pipeline permit did not involve a formal adjudicatory action. Due to the APA's protections against ex parte communication, bias, and prejudgment, an agency action driven by politicized variables or presidential pressures in such a formal setting would have clearly been illegal. ${ }^{437}$ Still, even in an informal adjudicatory setting involving numerous diverse opportunities for input, a presidential directive is problematic. ${ }^{438}$ After all, the deciding agency will, as with the Pipeline, face competing interests with substantial localized and personalized stakes hanging in the balance. A President is exceedingly unlikely to know about the risks, choices, and competing interests in play. A President is similarly unlikely to have any exposure to record materials that a delegated, responsible agency would have before it. A presidential directive about the desired outcome in such settings could, if obeyed, taint the regulatory action by introducing risks of bias or prejudgment violating the obligation of agencies to maintain an "open mind." 439

This action by President Trump-seeking to direct an outcome in a contentious informal adjudicatory setting over a permit—may have been without modern precedent. Other than a possible intervention in a formal proceeding, it is at the most problematic end of the spectrum, involving a micro-scale politicized intervention raising questions about legal fealty and attention to facts. ${ }^{440}$

\section{F. Statutory Abnegation and Dodged Facts}

Whether problematic policy change efforts reviewed above reflect well counseled strategic choices or blundering is hard to know. At least a few misguided or poorly justified policy change efforts are found during almost all administrations, and all have been met with a harsh judicial reception. ${ }^{441}$ But

437 See, e.g., Portland Audubon Soc’y v. Endangered Species Comm., 984 F.2d 1534, 1536 (9th Cir. 1993) (holding illegal White House interference with formal procedures required for deliberations of Endangered Species Committee).

438 See Sierra Club v. Costle, 657 F.2d 298, 397-410 (D.C. Cir. 1981) (reviewing huge number of communications from private entities, Congress, and executive branch officials in connection with notice-and-comment rulemaking, rejecting claim that they constituted illegal ex parte contacts, but stating unrecorded communications would raise different concerns in an adjudicatory context and that adequacy of rulemaking record was a separate issue).

439 "Open mind" and anti-bias constraints exist even in informal agency settings. See, e.g., Rural Cellular Ass'n v. FCC, 588 F.3d 1095, 1101 (D.C. Cir. 2009) (noting anti-bias constraints); Ass'n of Nat'l Advertisers, Inc. v. FTC, 627 F.2d 1151, 1154 (D.C. Cir. 1979) (discussing bias concerns and holding that Chairman of FTC could participate in pending rulemaking proceeding concerning advertising to children).

440 See Percival, supra note 3, at 2509-10, 2536-37 \& n.395 (discussing and citing literature on risks of presidential involvement in adjudications, facts as constraint, and discussing differences in formal and informal proceedings).

441 See supra Sections II.G, II.H (discussing judicial hostility to insufficiently explained agency policy change, including those initiated by Trump Administration). 
when a series of policy change proposals over a short period and under the same leadership reveal a fairly uniform series of justifications and strategies, then they may reflect a considered, intentional effort to move the law in a new doctrinal direction. ${ }^{442}$ The Trump Administration's many deregulatory actions share a fairly uniform set of justifications and even often the same citations. As discussed above, State Farm and Fox are often cited, with emphasis on the power of a President to push a new attitude about regulation, and then the somewhat questionable citation to the disputed Fox language from Justice Scalia's opinion about an agency not needing to show "better" reasons for the action. ${ }^{443}$ Some actions include the "underlying facts" language from Fox, but agencies have generally omitted analysis of consistency doctrine as articulated in Encino Motorcars - that majority opinion did not focus on the "better" language, but on the more standard need for agencies to provide "good reasons" for a change, leave no "unexplained inconsistency," and engage with "facts ... underlying" the initial action. ${ }^{444}$ None consider the implications of Massachusetts v. EPA, or the implications of the majority's rejection of the policy change at issue in State Farm due to the lack of an adequate explanation.

In these Trump Administration proposals and actions, however, agencies proposing change only cursorily engaged with the extensive documentation of facts and rationales provided by the very same agencies under the leadership of previous administrations. Instead, in a substantial number of major recent deregulatory actions, the agencies engaged in statutory abnegation, claiming either limited power due to a new statutory interpretation, or sometimes claiming they completely lack earlier claimed power. ${ }^{445}$

In positing such new constraining legal reads but then not engaging with previously critical facts and agency reasoning, these agencies implicitly seem to have manifested the following belief: that if an agency claims new limits on its own power through a new statutory interpretation, then it can avoid engagement with the empirical and scientific data earlier gathered and relied upon, the earlier reason-giving by the agency, and assessment of the effects of the different regulatory choices.

Such a strategy is unlikely to succeed, although in one highly unlikely narrow setting might be found acceptable despite its apparent violation of consistency

${ }^{442}$ During the presidency of George W. Bush, an analogous series of fairly uniform shifts in preemption policy triggered scholarly and judicial scrutiny. See generally PREEMPTION Choice: The Theory, LAW, ANd ReAlity of Federalism's Core Question (William W. Buzbee ed., 2009) (analyzing these preemption policy developments).

443 Encino Motorcars's more recent clear majority opinion omitted this language. See Encino Motorcars, LLC v. Navarro, 136 S. Ct. 2117, 2125-26 (2016) (focusing on need for explanations and attention to underlying facts).

444 See supra Section II.C (discussing Encino Motorcars decision).

445 See supra Sections I.E, II.H (discussing Trump Administration policy reversals and claims of lack of statutory authority). 
doctrine precedents. ${ }^{446}$ The strength or vulnerability of this revealed new strategy hinges on both the reasonableness of the agency's statutory view as well as ongoing judicial fealty to Supreme Court precedents requiring agencies proposing a policy change to engage with "underlying facts" and leave no "unexplained inconsistency." 447

If both the old and new statutory interpretations are tenable, then under the consistency-linked doctrines above, the agency cannot just embrace a new statutory view and policy yet not explain why it has done so. All of the consistency doctrine cases require the agency to provide a reasoned comparative analysis. The obligation to provide "good reasons" will require assessment of the rationales for and consequences of the new read and explanation why it is congruent with what the statute sets forth. The agency will need to offer "good reasons" for the change despite its previous embrace of a different policy. ${ }^{448} \mathrm{~A}$ claim about a new "better" or "belie[ved] to be better" policy provides some policy space for agency judgment, but requires agency discussion that compares the old and new approaches. ${ }^{449}$ None of these cases state that an agency's reliance on a changed view of statutory powers excuses the need for such analysis. Instead, they insist upon "good reasons."

Furthermore, if an agency errs about the nature of its authority, including an erroneous claim of lack of statutory ambiguity or erroneously narrow view of its own power, that is itself grounds for judicial rejection. ${ }^{450} \mathrm{~A}$ close judgment call will always go to the agency, but even such an agency victory requires correct statutory analysis, engagement with earlier actions, and persuasive explanation.

It is important to note that the EPA's statutory abnegation in Massachusetts v. EPA was a claim of no power to act regarding GHGs as an air pollutant, coupled with arguments rooted in agency and presidential discretion regarding policy priorities and even foreign policy. ${ }^{451}$ The EPA basically constructed an argument, built off of the Brown \& Williamson decision. It argued in its Federal Register preamble that, due to the breadth of the regulatory impacts, the generality of the statutory language, and the specificity of a few climate-related legislative authorizations, Congress had sent a collective legislative signal that

446 See infra note 454 and accompanying text (describing possible narrow use of such strategy that might be successful).

447 See supra Section II.C (reviewing cases setting forth these obligations).

448 See supra Section II.C.

449 See supra Section II.C; supra text accompanying notes 226-233 (discussing key language in Fox and various Court opinions).

450 See NextEra Desert Ctr. Blythe v. Fed. Energy Regulatory Comm’n, 852 F.3d 1118, 1122-23 (D.C. Cir. 2017) (finding agency erred regarding its own statutory authority); Daniel J. Hemel \& Aaron L. Nielson, Chevron Step One-and-a-Half, 84 U. CHI. L. REV. 757, 818-21 (2017) (analyzing cases holding that agency errors about nature of their own authority must be rejected).

451 See supra notes 215-224 and accompanying text (discussing actions leading to Massachusetts v. EPA and Court's ultimate decision). 
the agency had no power at all to regulate GHG emissions. ${ }^{452}$ The Supreme Court, however, rejected the reading as erroneous, and saw no space for the other claimed political factors to excuse inaction. The Court insisted that the agency ground its decision in a correct application of the statute's criteria and required the agency to engage with relevant underlying science and make the judgments mandated by the statute. ${ }^{453}$

The only possible doctrinal space for a successful statutory abnegation move that neglects earlier contingencies is if both the agency and the reviewing court agree that the abnegating agency was correct, as a Chevron Step One matter, that the agency never had any power to act in any way as it earlier claimed and did. ${ }^{454}$ Perhaps in the setting of a complete regulatory turf disavowal, a later reviewing court would, despite the absence of supporting Supreme Court consistency doctrine language, allow the policy change without full provision of "good reasons," or full engagement with "underlying facts" and possible reliance interests. The argument would likely be that such context-specific contingency analyses were always legally irrelevant or illegal. And, were the abnegating agency and a reviewing court later to agree that the agency, in taking its earlier actions, had no such power to act in the first place, perhaps that limited rationale and reasoning would suffice.

The very circumstance of such agreement is unlikely, however. After all, the agency would need to successfully claim, contrary to its own earlier fully explicated view, that only a single contrary reading of the law is tenable. Moreover, if the abnegation is in any way factually contingent, or is really a claim of past overreach in a particular application, it would be far from a power disavowal that might arguably excuse a lack of agency justification and lack of engagement with regulatory contingencies. A later agency claim of initial illegal excess is actually, at most, either a new slightly different read of the agency's power, or a mere professing of past arbitrary and capricious action. Or, most likely, it would actually involve a Chevron Step Two interpretation proffering a new and (allegedly) better read and policy.

If such statutory abnegation is actually rooted in such claims of agency excess or a new choice among several options, then the agency would still need to fully explain and justify itself. Such actions would involve an agency choice to change

452 Massachusetts v. EPA, 549 U.S. 497, 512-13 (2007) (referencing EPA's reliance on FDA v. Brown \& Williamson Tobacco Corp., 529 U.S. 120 (2000)). This sort of interpretive move under the "major questions" or "power" canon is sometimes characterized as a conclusion of no power under Chevron Step One, but in others as a setting that leads to "no power" or "no deference" conclusions, basically bypassing the Chevron framework altogether. See generally Heinzerling, supra note 80 (discussing what author calls "power canons”).

453 See Massachusetts v. EPA, 549 U.S. at 534 (holding that proffered reasons for lack of action by EPA were arbitrary and capricious).

${ }^{454}$ For discussion of Chevron and its implication for policy change, see supra notes 183197 and accompanying text. For additional discussion of the "major questions" or "power canon,” see supra notes 80-81 and accompanying text. 
policy, not mere compliance with what statutorily must be. As stated in the major consistency doctrine cases, an agency choosing to change policy must provide "good reasons" for the change. ${ }^{455}$ Such policy changes would really not be driven by language, but by claims about what range of choices are legally allowed or best.

And when one considers the "major questions" or "power" canon's foundations and logic, even those possible rationales for abnegation would, upon closer examination, not logically excuse an agency's lack of engagement with key contingencies and past reasoning. Much of that canon's reasoning is based on claims that particular interpretive choices would result in massive regulatory consequences. ${ }^{456}$ If a new agency action is designed to mitigate claimed regulatory excess, then there too the apparent claim of "no power" might actually just involve a degree of agency forbearance or pullback. To draw that line between illegal excess or prudent self-limitation in asserting regulatory authority would logically, under the consistency cases, call for the agency and reviewing courts to engage fully in comparative analysis of statutorily relevant contingencies and regulatory consequences. Hence, a later complete disavowal of agency power to act is highly unlikely to thread this jurisprudential needle.

Where the relevant statutory language mandates that an agency engage in some variant of "best" achievable analysis, an agency abnegation claim is especially unlikely to succeed. ${ }^{457}$ The nature of the statutory requirement creates substantial constraint. ${ }^{458}$ Undoubtedly, some judgment calls shape agency definition of the relevant category for comparison. ${ }^{459}$ But leapfrogging back to some claimed consistency with a distant "best" benchmarking while ignoring an intervening agency interpretation, justifications, reasoning, and regulatory effects would seem to flunk all of consistency doctrine's requirements. ${ }^{460}$ An agency explaining what is "best" to achieve a statutory goal will, in a policy change setting, necessarily require comparative assessments.

455 Encino Motorcars, LLC v. Navarro, 136 S. Ct. 2117, 2125-26 (2016) (requiring “good reasons").

456 For discussion of this canon, see supra notes 80-83 and accompanying text.

457 Such statutory mandates and their data and science-intensive nature are presented and analyzed elsewhere in this Article. See supra notes 422-433 and accompanying text.

458 See supra Section IV.D.

459 Battles over the Clean Power Plan and consideration of capabilities "inside the fenceline," as advocated by the Trump Administration, or of how power plants and their owners already achieve substantial GHG reductions through trading and other shifts that may physically occur off-site (the Obama Administration EPA view), involve just such questions about comparators under regulatory benchmarking.

${ }^{460}$ Early Clean Power Plan and Waters of the United States deregulatory actions never grappled with empirical and peer reviewed studies previously documented. By late 2018, following a series of judicial rejections of agency deregulatory actions, the EPA engaged in more substantial analysis. See supra Section I.E.5 (presenting such actions); Section II.H (discussing cases assessing actions); Section III.B (providing broader assessment of legality of these regulatory shifts). 
Moreover, in major recent opinions, the Supreme Court has increasingly been emphasizing the need to read key language with attention to surrounding context. ${ }^{461}$ These cases also reflect a focus on the consequences of interpretive choices and whether they can be reconciled with all statutory signals about a statute's meaning and stated purposes. ${ }^{462}$ The Court has castigated agencies for "interpretive gerrymanders," where an agency strategically and unnecessarily refuses to consider all costs and benefits-also referred to as "advantages" and "disadvantages"- that result from a regulatory choice. ${ }^{463}$ An agency cannot keep "parts of statutory context it likes while throwing away parts it does not." 464 Recent scholarship investigating appellate judges' interpretive practices reveals similar broad pluralistic and pragmatic inquiry, and little actual use of a purely textualist approach as espoused by Justice Scalia. ${ }^{465}$ Thus, both under consistency precedents and a related line of statutory interpretation opinions, for an agency to show deliberative integrity will require the following: the agency will have to engage with all salient language, the on-the-ground effects of choices permitted by the law's relevant operative text, and surrounding contextual language and other clues as to permissible meanings.

With the Clean Power Plan's proposed abandonment or change under the Trump administration, for example, courts reviewing the agency's actions will assess if the agency justified its proposed new fenceline-bound statutory reading according to the relevant emission standard, which requires identifying what is the: 1) best 2) system (not technology) of 3) emissions reduction that has 4) been adequately demonstrated. ${ }^{466}$ The linked language provides numerous levels of

461 See, e.g., King v. Burwell, 135 S. Ct. 2480, 2488-89 (2015) (working with language from FDA v. Brown \& Williamson Tobacco Corp., 529 U.S. 120, 133 (2000), about attention to context, but looking more broadly at functionality and impacts); Util. Air Regulatory Grp. v. EPA, 134 S. Ct. 2427, 2439-49 (2014) (looking at context, structure, and impacts to conclude EPA lacked power to regulate small emitters despite literal language reaching them).

462 See King, 135 S. Ct. at 2488-89; Brown \& Williamson Tobacco Corp., 529 U.S. at 133; Util. Air Regulatory Grp., 134 S. Ct. at 2439-49.

463 See Michigan v. EPA, 135 S. Ct. 2699, 2707-11 (2015) (rejecting EPA claim of no power also to consider costs associated with its regulation to reduce risks of mercury pollution from power plants). The dissent, written by Justice Kagan for herself and three other Justices, agreed with a general default rule that reasonable agency action requires consideration of costs unless precluded by the statute, but thought the EPA did so. Id. at 2716 (Kagan, J., dissenting). Hence, the whole Court appears to have embraced this new substantive canon regarding consideration of both benefits and costs of agency actions, but the justices differ in its application.

${ }^{464}$ Id. at 2708 (majority opinion).

465 Abbe R. Gluck \& Richard A. Posner, Statutory Interpretation on the Bench: A Survey of Forty-Two Judges on the Federal Courts of Appeals, 131 HARV. L. REV. 1298, 1309-15 (2018) (summarizing these findings).

${ }^{466}$ See Clean Air Act of 1963 §§ 111(a)(1), (d), 42 U.S.C. §§ 7411(a)(1), (d) (2012) (providing operative and definitional provisions underpinning CPP and guiding any policy change). 
tethering, as do past EPA studies and reason-giving that discussed what is actually happening in the states, pollution control, and clean energy trends. ${ }^{467}$ So far, however, we do not know why the EPA thinks the "inside-the-fenceline" approach satisfies these criteria for setting of a performance standard, how it is "best" to reduce emissions, let alone "good reasons" for the change. ${ }^{468}$ Regulatory materials so far leave "unexplained inconsistency" and minimal acknowledgement of changed views of "underlying facts."469

Under the very different Clean Water Act "waters of the United States" regulation, the statutory language is, viewed alone, both broad in its reach and quite indeterminate. ${ }^{470}$ But the 2015 Clean Water Rule was woven out of close attention to three decades of regulatory experience, three major Supreme Court decisions, the Connectivity Report's survey of peer-reviewed science about waters, and the Clean Water Rule's explanation for its line-drawing choices about what waters should be protected. ${ }^{471}$ They collectively created a substantial body of contingent analysis that under current consistency doctrine must be engaged with by the agency when revising policies. So far, however, the agencies that proposed these changes (the EPA and the Army Corps) have, through their divided steps and notice choices, in addition to limiting comment, substantially limited discussion of these issues. These shortcuts led to judicial rejection of the "Applicability Date" regulation due to the agencies' failure to make policy changes in conformity with requirement of the Clean Water Act and APA. ${ }^{472}$ So far, in these various actions, the EPA and the Army Corps imply something illegal in the past approach. They also, in compliance with a presidential order, have proposed adopting Justice Scalia's non-majority view of federal power. Until the 2018 Supplemental Notice, the agencies had avoided explanation for how these approaches would be permissible under the law and analysis of related effects. ${ }^{473}$

Finding the correct answer to these particular policy shifts is beyond the scope of this Article, not least because the finality and legality of most of these actions and subsequent litigation will not be resolved for years. However, they reveal questionable self-constraining reads of statutory power to justify lack of

467 Both 2015 and 2017 studies and agency actions will need to be engaged. See supra notes 133-143 and accompanying text.

468 This series of actions is presented elsewhere in this Article. See supra notes 133-147 and accompanying text.

469 See supra notes 133-147 and accompanying text.

470 See supra notes 113-132 and accompanying text.

471 See supra notes 113-132 and accompanying text.

472 See S.C. Coastal Conservation League v. Pruitt, No. 2:18-cv-00330, slip op. at 6-18 (D.S.C. Aug. 16, 2018).

473 The 2018 Supplemental Notice offers more in-depth discussion, but may still be based on a statutory interpretation that is illegal and only provides limited engagement with the relevant science and the effects of the old and likely new regulatory approaches. See supra notes 130-132 and accompanying text (citing and presenting action); supra notes 372-375 and accompanying text (discussing actions' legality). 
engagement with the heart of the statutory tasks, goals, and direct comparative assessment of regulatory effects of the old and new actions.

If courts accept this new statutory abnegation strategy to achieve policy change-a new agency-proffered self-limiting statutory read, and minimal engagement with underlying facts and past reason-giving - then agencies would have broad newfound ability to sidestep the linked requirements of consistency doctrine and "reasoned decisionmaking" jurisprudence. Statutory abnegation, in particular, would become the new means to deregulate or achieve major policy changes. If accepted by reviewing courts, agencies could avoid discussion of onthe-ground repercussions of the choice, their own past reason-giving, and also the agencies' earlier explanations for why different, more broadly empowering reads were embraced. Courts would have to abandon a vast body of longstanding administrative law doctrine.

Furthermore, such an embrace of this policy change strategy as legal would exacerbate Justice Gorsuch's concerns-although he overstated them-with agency power to shift policy day-to-day, based on regulatory "whim." ${ }^{474}$ Such a change would also undercut the values of stability and the judicially enforced norm that agency policymaking should be rigorous, offer publicly accessible and rational explanation, and be based on the best data and science. ${ }^{475}$ Administrative law doctrine generally tries to hold in equipoise room for political responsiveness while also looking for expert, fact-based agency policymaking guided by congressional criteria. If such a shift in doctrine were permitted, it would decidedly skew agencies in a politicized direction and allow more rapid and unpredictable policy change. A focus on language and power disavowal could be used to avoid expertise-based analysis of choices and their effects.

But consistency doctrine's many facets make such doctrinal upheaval unlikely. To embrace such agency power to disavow power and thereby avoid justification obligations would involve at least the following major doctrinal adjustments. Chevron deference would be substantially expanded, with Step Two reasonableness oversight weakened. The whole line of "hard look review" and "reasoned decisionmaking" precedents would be substantially weakened and susceptible to strategic agency sidestepping of criticisms and engagement with data and past agency policy explanations. The still uncertain middle of consistency doctrine's major cases-how much can a President's or political appointees' regulatory predilections shape an agency's actions-would expand; agencies and presidents would have broadened latitude to follow their preference for laxity or stringency. Agency obligations to look both backwards and forwards to explain fully and frankly a policy shift would be weakened. The key

\footnotetext{
474 See supra Section I.B (describing these views).

475 Although many laws do not mandate reliance on such best available science or data, the rigor of "hard look review" and linked reasoned decisionmaking expectations will generally lead agencies in high stakes policymaking settings to rely on best available data to avoid later judicial rejection.
} 
lessons of Massachusetts v. EPA and State Farm about fealty to statutory criteria over statutorily untethered political preferences would be subject to a new gaping exclusion. "Unexplained inconsistency," which is now prohibited, would become common. ${ }^{476}$ Abrupt statutory interpretation shifts would become more frequent, and agencies could disregard more of their past work, others' views, and facts.

Even if judges assessing these deregulatory justifications shared a preference for less regulation, the long-term systemic costs of freeing agencies and presidents to make more abrupt and politically driven policy changes under the guise of power disavowals would-or should—give them pause. Such a doctrinal shift would create associated increases in discretionary agency power, heighten legal instability, and reduce political accountability to affected stakeholders. It would also undercut rule of law virtues like stability, predictability, and reasoned explanation by lawmakers. ${ }^{477}$

For these reasons, jettisoning of consistency doctrine through embrace of this apparent new strategy of agency statutory abnegation is unlikely. It might work in the rare and unlikely setting of agency and court agreement that the agency never had any authority to act at all in a setting where it previously claimed power. But narrower and contingent forms of abnegation should not excuse full agency engagement with contingencies or allow agency bypassing of burdens of justification. Broader embrace of this strategy would destroy the stabilityresponsiveness equipoise of current consistency doctrine. And several decades of case law governing agency consistency, as well as the first judicial opinions assessing the 2017 and 2018 deregulatory wave of actions, consistently hew to these longstanding requirements.

\section{CONCLUSION}

The law shaping agency power to change policy is built on a web of legal doctrine that shares common expectations and requirements. Contrary to recent claims of broad agency and presidential power to change policy with little constraint-claims that were stated with condemnation by now-Justice Gorsuch but embraced by administration agencies during the early years of the Trump Administration-policy change is subject to numerous hurdles. Agencies cannot run from underlying facts, contested issues, or past statutory interpretations and associated reasoning explaining past policy choices. Agencies must engage with these statutorily shaped contingencies. This body of doctrine tethers both presidents and agencies, but leaves substantial room for improved regulation and adjustment to new circumstances. If broad recent assertions about unfettered change power meet with success, that will likely mean a substantial change in

476 Encino Motorcars, LLC v. Navarro, 136 S. Ct. 2117, 2125 (2016).

477 Cf. Cass R. Sunstein \& Adrian Vermeule, The Morality of Administrative Law, 131 HARV. L. REV. 1924, 1947-55 (2018) (discussing "rule of law” values, consistency doctrine, and reliance interests in analysis of "morality" of administrative law as reflected in core modern doctrine and framed by jurisprudential writings). 
the contours of consistency doctrine. Many of the current checks on agency lawlessness and arbitrariness would be weakened. The web of doctrines making up consistency law are well founded, however, and should endure, checking unjustified and unaccountable agency policy shifts. 